UNIVERSIDADE DE SÃO PAULO

FACULDADE DE FILOSOFIA, LETRAS E CIÊNCIAS HUMANAS

DANIEL REIZINGER BONOMO

\title{
Colocutores em trânsito
}

Os tontos movimentos dos romances Grande Sertão: Veredas e Berlin Alexanderplatz 
DANIEL REIZINGER BONOMO

\section{Colocutores em trânsito}

Os tontos movimentos dos romances Grande Sertão: Veredas e Berlin Alexanderplatz

Dissertação apresentada à Faculdade de Filosofia, Letras e Ciências Humanas da Universidade de São Paulo para obtenção do título de Mestre em Letras.

Área de Concentração: Língua e Literatura Alemã Orientador: Prof. Dr. Helmut Paul Erich Galle

São Paulo

2007 


\section{Agradecimentos}

Ao Prof. Dr. Helmut Galle, que, desde os meus anos de graduando da Faculdade de Letras, ensinou-me a crescer com seriedade e prazer pelos meus estudos.

Ao Prof. Dr. João Adolfo Hansen, pela atenção e paciência que sempre dedicou ao meu trabalho.

Ao Prof. Dr. Carl Wege, pelo companheirismo e rara amizade.

À Coordenação de Aperfeiçoamento de Pessoal de Nível Superior pela concessão da bolsa de mestrado e pelo apoio financeiro para a realização desta pesquisa.

Aos amigos do Instituto de Estudos Brasileiros da Universidade de São Paulo.

Às seguintes pessoas, que, em algum momento e de algum modo, ajudaram-me: Ana Cândida Franceschini de Avelar Fernandes; Ana Flora Franco, Artur Voltolini, Gabriela Reizinger Bonomo, Henrique Ribeiro, Henrique Piccinato Xavier; Marcela Abreu Guimarães, Márcio Guimarães Araújo, Maria Luiza Xavier Souto, Maurício Fleury, Pedro Heise e Sérgio Hannemann.

Aos meus pais, pela compreensão e carinho dedicados.

À Joana Souto Guimarães Araújo, pela presença em minha vida. 


\section{Resumo}

O paralelismo entre os romances Berlin Alexanderplatz e Grande Sertão: Veredas surge na crítica literária brasileira a partir de um comentário de Davi Arrigucci Jr. Com o intuito de prosseguir a discussão levantada, faz-se aqui uma análise mais detalhada dos elementos que os aproximariam como representantes do discurso do romance moderno. Privilegiam-se, para tanto, as movimentações que caracterizam as trajetórias dos protagonistas Franz Biberkopf e Riobaldo, com a observação dos deslocamentos das personagens no espaço, emocionalmente, e também com a atenção que deve ser dirigida ao trânsito que opera a narrativa dos dois romances. Devem ser destacadas, com isso, particularidades desses romances que melhor os situam na tradição que os associa aos livros Os Anos de Aprendizagem de Wilhelm Meister e A Educação Sentimental.

Palavras-chave: Berlin Alexanderplatz; Grande Sertão: Veredas; Movimentação; Romance moderno. 


\begin{abstract}
The parallel between the novels Berlin Alexanderplatz and Grande Sertão: Veredas was first drawn within the Brazilian literary criticism in a comment made by Davi Arrigucci Jr. With the intent of pursuing the discussion raised by the author, this article proposes a more detailed analysis of the elements which define both texts as representative works of the modern novel discourse. The analysis focuses on the movements which characterize the trajectories taken by the protagonists Franz Biberkopf and Riobaldo, with a view on the characters' transit in space, as well as emotionally, and also in regard to the transit that operates the narration within both novels. In this light, the article outlines the particularities which situate both novels within the tradition that associates them with the books Wilhelm Meisters Lehrjahre and L'Éducation Sentimentale.
\end{abstract}

Keywords: Berlin Alexanderplatz; Grande Sertão: Veredas; Movement; Modern novel.

\title{
Zusammenfassung
}

Die Parallelen zwischen den Romanen Berlin Alexanderplatz und Grande Sertão: Veredas werden in der brasilianischen Sekundärliteratur seit Davi Arrigucci Jr.s Kommentar sichtbar. In der Absicht, die dort begonnene Diskussion fortzusetzen, werden hier die Elemente im Detail untersucht, die beide Texte als Exponenten des modernen Romans einander annähern würden. Besonderes Augenmerk gilt den für die Laufbahn beider Protagonisten charakteristischen Bewegungen, den räumlichen und emotionalen Veränderungen der Figuren sowie insbesondere dem „Verkehr“, der die Erzählung in beiden Romanen vorantreibt. Hiermit sollen die Besonderheiten dieser Romane, die sie in einer gemeinsamen Traditionslinie mit Wilhelm Meisters Lehrjahre und der L'Éducation Sentimentale verorten.

Stichwörter: Berlin Alexanderplatz; Grande Sertão: Veredas; Bewegung; moderner Roman. 
Procuramos inutilmente fixar um círculo, uma paisagem em que nosso espírito se compraz, mas a vida é terrivelmente móvel. (Cyro dos Anjos, O Amanuense Belmiro) ${ }^{*}$.

${ }^{*}$ ANJOS, Cyro dos. O Amanuense Belmiro. $15^{\mathrm{a}}$ ed. Belo Horizonte: Livraria Garnier, 2000, p. 167. 


\section{Sumário}

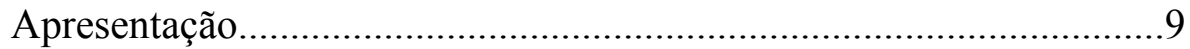

Problemas da forma romanesca.................................................. 18

Berlin Alexanderplatz e Grande Sertão: Veredas.............................35

Andeja vida: Riobaldo..............................................................43

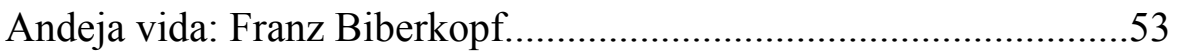

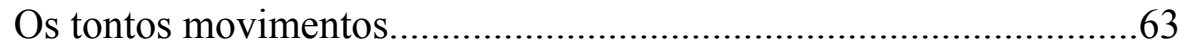

Ventos de não deixar se formar orvalho........................................83

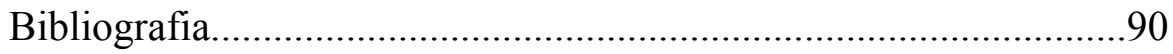




\section{Apresentação}

Caso escolhêssemos, na ordenação de uma pequena coleção de livros, justapor os romances Berlin Alexanderplatz (1929) e Grande Sertão: Veredas (1956), faríamos isso sobre qual superfície? Pode ser que o ato causasse algum estranhamento, afinal, qual foi seu impulso? O que se entende com isso? De quais critérios se pode fazer uso para justificar tal vizinhança?

Recorreríamos à ajuda daquele plano injusto de um intrigante heteróclito, incerto na ausência de leis aparentes, ou assumiríamos como total arbitrariedade a improvável escolha? Certamente não nos bastaria argumentar que ambos os autores, Alfred Döblin e João Guimarães Rosa, foram médicos ou coisa do tipo, tampouco que tiveram seus textos capitais transformados em séries televisivas, pois logo saltariam as diferenças em maior número e importância, tornando insustentáveis esses argumentos que não se satisfazem em qualidades próprias dos textos. Ora, num deles estamos em um grande espaço urbano intensamente habitado, barulhento, confuso na multidão de veículos passantes, pedestres, construções em andamento etc., e no outro o que temos é a amplitude de um espaço vazio, abandonado, por vezes, aos cantos de um vento ou de uma ave; num deles encontramos uma narrativa extremamente fragmentária, descontínua, amontoados de peças discursivas, enquanto no outro presenciamos um fluxo narrativo ininterrupto de grande fôlego; a consciência da personagem protagonista de um deles parece não ter muitas práticas reflexivas, mas a do outro sim, pois fala, incontinência verbal, durante todo o romance, "especulando idéias"; e assim poderiam ainda seguir outras destas distinções que rápido se impõem.

Talvez aproximar os dois romances numa estante trouxesse o conforto de um jogo compensatório, talvez Riobaldo pudesse, com a sua presença, pensar por Franz Biberkopf, ajudá-lo com suas idéias; ou, então, seria Franz Biberkopf que tranqüilizaria Riobaldo, ensinando-lhe a esquecer e sufocar suas angústias com alguns tragos; talvez o silêncio do sertão acalmasse um pouco Berlim ou, pelo contrário, as agitações berlinenses é que animariam um pouco a calmaria sertaneja. Mas um mecanismo compensatório gratuito, brincalhão apenas tranqüilizaria o aparente disparate; seria antes preciso colocar à prova, rastrear semelhanças na diferença ela própria, encontrar uma comunidade em 
seus modos narrativos, em qualidades que justificassem que ambos, Berlin Alexanderplatz e Grande Sertão: Veredas, estão sim próximos, para um necessário diálogo que se dá na esfera dos grandes romances do século XX.

Curioso é pensar que, quem sabe com a mesma arbitrariedade, James Joyce (Ulysses) ou Carlo Emilio Gadda (Quer Pasticciaccio Brutto de Via Merulana, por exemplo) poderiam ser convidados a participar e ampliar nossa talvez desarrazoada aproximação de distantes, o que nos faria imediatamente notar que, sobre todas as semelhanças e distinções possíveis, atrairia uma em particular: Döblin e os dois novos companheiros estão num mundo urbano, citadino, mas o brasileiro Guimarães Rosa resiste, elegendo para o conjunto de paradigmas da escrita romanesca do século XX um livro que se escreve sobre um solo e mundo outros: o sertão brasileiro, território em tudo oposto ao espaço que melhor define a experiência moderna, o espaço da cidade.

Teria a cidade de São Paulo chegado atrasada ao rol das metrópoles do século $\mathrm{XX}$ ? Certamente, mas isso com certeza não explicaria melhor a questão. Pode-se perguntar, como já se fez, pelos motivos da não-existência de um correspondente urbano para a posição que o Grande Sertão: Veredas ocupa na literatura brasileira, mas essa pergunta necessariamente evita recair sobre Guimarães Rosa, que, muito provavelmente, não haveria de ficar seduzido com a agitação do centro de São Paulo que hoje conhecemos. Na leitura da obra de Guimarães Rosa, constata-se que ele preferiu a vivência e imaginação sertanejas como matéria de sua ficção, podendo até recordar-se que ele, funcionário da diplomacia que foi, percorreu e fixou residência em várias localidades urbanas, como Hamburgo, Paris e Rio de Janeiro, sem que a nenhuma delas tenha sido possível colocar-se lado a lado, como tema de seus livros, com aquela Cordisburgo e região que o escritor deixou aos dez anos de idade. Pode ser instrutivo observar como ele registra suas impressões em uma nota daquele problemático período em que viveu na Alemanha (trata-se de uma observação de um passeio, provavelmente em 1940):

Die Lüneburger Heide = stille Insel, no meio das atividades industriais e militares no Novo Reich em (re)construção. Como um vácuo. Chão barato e pobre. (m/.) Agora há estradas asfaltadas, a indústria se localiza aqui, de preferência, por ser pobre o solo para a 
agricultura, e as indústrias, ocupando-o, oneram de pouco a agricyltura. De um dia para o outro, aldeias começam a virar cidades. Um trem-de-ferro passa, pequenino, na planície, fumando entre pinheiros e carvalhos. $(\mathrm{m} / .)^{1}$.

Ou então esta outra, também em 1940 (provavelmente):

\section{$\underline{\text { HARBURG }}$}

Grande movimento às margens do rio, com tôda a navegação dos vaporzinhos do Elba. Um dos últimos tettos de palha, com um ninho de cegonha na cumieira (frontão, empena). no meio de um pomar. Ao lado de vacas pastando, erguem-se modernas fábricas, um quadro raro de desenvolvimento rápido.

A cidade se mistura com o campo. Já em Wilhelmsburg, (Himmelfahrt) os rostos dos passageiros do bonde se mudaram, maravilhosamente. Não são só gente tão de cidade. As crianças teem caras tostadas, amorenadas. Roupas lavadas, de todas as cores, se penduram, perto das casas. nas cordas, ao vento. Muitos jardins, rodeando as casas. Caminhões e autos. Pontes, braços de rio, guindastes, docas, ferrovias portuarias (trilhos) armazéns: cara de Harburg voltada para o sul ${ }^{2}$.

$\mathrm{Na}$ apreensão do espaço urbano de Guimarães Rosa há reservas. Pode-se até encontrar um certo tom de lamento em suas observações sobre o desenvolvimento industrial que prejudica a agricultura. Parece mais animar Guimarães Rosa a distância deste mundo de bondes e fábricas, quando, "maravilhosamente", mudam-se as fisionomias observáveis para algo que não corresponda mais àquilo identificado como "gente tão de cidade". Mas prende a atenção, contanto que se observe a complexidade dos elementos tratados nas notas, um tema central da observação: trata-se da coexistência de elementos urbanos (fábricas, bondes, automóveis, estradas asfaltadas) com elementos rurais (vacas pastando, um teto de palha com um ninho de cegonha, agricultura) numa paisagem em que "a cidade se mistura com o campo", e isso pode já contribuir para que

\footnotetext{
${ }^{1}$ Foi mantida a grafia original, sem que se fizessem correções sobre o texto. $\mathrm{O}$ documento faz parte do espólio do escritor pertencente ao Instituto de Estudos Brasileiros da Universidade de São Paulo (IEB/USP). Cf. FJGR. MJGR - EO. Cx. 01, 01 (173). 26/33.

${ }^{2}$ Cf. FJGR. MJGR - EO. Cx. 01, 01 (173). 27/33. Também aqui foi mantida a grafia original.
} 
se pense algo além daquela desgastada oposição entre campo e cidade, que poderia, por sua vez, opor representações literárias como o Grande Sertão: Veredas e o Berlin Alexanderplatz. Nessa região fronteiriça observada nas notas, deflagra-se uma complexidade mais que social da relação entre campo e cidade, fato que seguramente não escapou à sensibilidade de Guimarães Rosa e a sua ficção.

Sem que se queira conferir demasiada importância às notas comentadas, deve aqui ser registrado que, de algum modo, a mais recente crítica do Grande Sertão: Veredas, em nomes como os de Ettore Finazzi-Agró, João Adolfo Hansen e Willi Bolle, por exemplo, já reconhece como ele se presta à mediação dos ambientes urbano e sertanejo, especialmente em sua condição narrativa, que propõe uma espécie de diálogo entre um narrador sertanejo, Riobaldo, e um ouvinte que de alguma cidade chega para ali permanecer calado. "Muito falo, sei; caceteio. [...] Mas o senhor calado convenha" (GSV, p. 133$)^{3}$.

Será preciso, no entanto, reconhecer, para a particularidade de nossa aproximação, que, embora em muitos aspectos distintos, existem elementos da narrativa romanesca que em si fazem os livros de Guimarães Rosa e Alfred Döblin participar de uma mesma realidade. Se a modernidade da prosa brasileira do século XX está exemplarmente no romance Grande Sertão: Veredas, podemos pensar como este livro dialoga com outros paradigmas dessa mesma modernidade, como o Berlin Alexanderplatz, por exemplo.

Houve já quem notasse uma possível aproximação destes dois romances. Davi Arrigucci Jr. deve ser considerado o primeiro crítico a ladear Alfred Döblin e Guimarães Rosa $^{4}$. Arrigucci, contudo, não aprofunda a questão comparativa, limitando-se a uma breve menção, que sua análise do Grande Sertão: Veredas possibilita, aos comentários que faz Walter Benjamin sobre o Berlin Alexanderplatz em seu conhecido texto Crise do Romance (Krisis des Romans). Acompanhemos:

\footnotetext{
${ }^{3}$ A edição do Grande Sertão: Veredas aqui utilizada é a seguinte: ROSA, João Guimarães. Grande Sertão: Veredas. $2^{\mathrm{a}}$ ed. Rio de Janeiro: José Olympio, 1958. Sempre que essa edição for citada, será com a sigla GSV.

${ }^{4}$ Bem anterior, também o texto A Linguagem do Iauaretê, de Haroldo de Campos, menciona o nome de Alfred Döblin; no entanto, o autor não dá à aproximação dos dois romancistas significativa atenção. Cf. CAMPOS, Haroldo de. A Linguagem do Iauaretê. In: Guimarães Rosa. Eduardo F. Coutinho (org.). $2^{\mathrm{a}}$ ed. Rio de Janeiro: Civilização Brasileira, 1991, pp. 574-579. (Coleção Fortuna Crítica).
} 
Pelo lado da restauração da poesia épica, muito afastada do universo do romance europeu há séculos, talvez a comparação mais adequada, pela direção do projeto, fosse com Alfred Döblin, que se opõe, no final da década de vinte, à herança flaubertiana da escrita do romance, por outro lado, tão vigorosa em Joyce ou no André Gide de Les faux monnayeurs. Opondo-se a essa herança, em que o romance é visto como uma forma escrita, Döblin voltou-se também para a linguagem falada, o dialeto berlinense, servindose da montagem de documentos heterogêneos da vida cotidiana e glosando o estilo das narrações populares, para fazer explodir estrutural e estilisticamente o romance. Como se vê, porém, o seu é um mundo urbano e muito diferente daquele que serviu aos propósitos de Guimarães Rosa, anos mais tarde. Mas, se é bem verdade, como observou Benjamin, que a trajetória de Franz Biberkopf de proxeneta a pequeno-burguês, no mundo dos marginais em torno do centro comercial que é a Alexanderplatz de Berlim, constitui um avatar do romance de formação do período burguês, também a travessia de Riobaldo em meio aos jagunços do sertão mineiro o é. Se, no primeiro caso, temos uma espécie de Educação sentimental de um marginal; no outro, temos igualmente a Educação sentimental de um jagunço ${ }^{5}$.

A questão levantada concentra-se no modo épico dos dois romances, em grande parte entendida pelo efeito da ilusão de oralidade que neles habita, e retoma em seguida o problema em torno do Bildungsroman, problema cujos desdobramentos, a partir dessa observação de Benjamin, aqui por Arrigucci revisitada, ganharam relevância na literatura crítica de Döblin.

Interessante notar que, nos poucos comentários que recebe Berlin Alexanderplatz no Brasil, geralmente estão associados o texto de Walter Benjamin escrito em 1930, precisamente, e o livro de Döblin, de 1929. O contexto em que estão inseridos ambos é o de uma "crise do romance" tomada como um problema geral, como o sinal de um tempo em que romances do século XIX, então modelos tradicionais, já não mais deveriam ser possibilidades comuns à representação literária moderna. Generalizada, afirmamos, pois não apenas Walter Benjamin e Döblin trataram dessa "crise", uma discussão bastante significativa àquele momento (na passagem da década de 1920 para a de 30), mas

\footnotetext{
${ }^{5}$ ARRIGUCCI JR. Davi. O Mundo Misturado. Romance e Experiência em Guimarães Rosa. In: Novos Estudos CEBRAP. ‥ ${ }^{\circ} 40$, novembro de 1994, p. 21.
} 
também autores como Otto Flake e Robert Musil, por exemplo, deram no período suas opiniões.

Em seu texto, Benjamin reconhece que Alfred Döblin "não se resigna com essa crise, mas antecipa-se a ela e a transforma em coisa sua"6. Admirado que estava com a leitura do Berlin Alexanderplatz e do texto teórico de Döblin que lhe serve de apoio, $A$ Construção da Obra Épica (Der Bau des epischen Kunstwerks, 1928), Walter Benjamin chega a considerá-lo, Döblin, um "narrador nato", "insurgindo-se contra o romancista" que seria um Flaubert. Se quando Benjamin escreveu o seu bastante reconhecido contributo à teoria literária, O Narrador (Der Erzähler, 1935/36), Alfred Döblin não representasse já para ele um membro da "inteligência burguesa de esquerda", talvez o autor de Berlin Alexanderplatz pudesse também figurar como objeto de suas considerações que são desenvolvidas sob o exemplo de Nicolai Leskov, nome que hoje muita vez precisa do acompanhamento de uma nota explicativa. Döblin não participou da luta de classes no sentido em que Benjamin pensava melhor funcionar um intelectual socialmente, interagindo no processo produtivo propriamente, mas, antes, como um "protetor" do proletariado, um "mecenas ideológico", como se lê em seu texto O Autor como Produtor (Der Autor als Produzent, 1934) ${ }^{7}$.

De um ponto de vista unicamente literário, podemos em uma análise conciliar muito bem alguns argumentos dos textos teóricos de Döblin e Benjamin, sobretudo nos temas da “objetividade épica”. Mas algo nos horizontes políticos de ambos parece que foi oposto, e poderíamos hoje apenas imaginar quão notória seria a contribuição que os estudos sobre Döblin e seu Berlin Alexanderplatz receberiam, caso houvesse Benjamin

\footnotetext{
${ }^{6}$ BENJAMIN, Walter. Krisis des Romans. Zu Döblins Berlin Alexanderplatz. In: Gesammelte Schriften III. Frankfurt am Main: Suhrkamp, 1972, p. 231. Ed. brasileira: BENJAMIN, Walter. A Crise do Romance. In: Obras Escolhidas I. $7^{\text {a }}$ ed. Tradução de Sergio Paulo Rouanet. São Paulo: Brasiliense, 1994, p. 55.

${ }^{7}$ BENJAMIN, Walter. Der Autor als Produzent. Ed. brasileira: BENJAMIN, Walter. O Autor como Produtor. Conferência Pronunciada no Instituto para o Estudo do Fascismo, em 27 de Abril de 1934. In: Obras Escolhidas I. $7^{\text {a }}$ ed. Tradução de Sergio Paulo Rouanet. São Paulo: Brasiliense, 1994, pp. 120-136. Benjamin observa nesse texto que naqueles primeiros anos da década de 1930 o "conceito de intelectual ganhou terreno no campo da inteligência de esquerda e domina seus manifestos políticos, de Heinrich Mann a Döblin" (p. 126), e que tal conceito, no entendimento de autores como Döblin, era determinado por uma "concepção do 'intelectual' como um tipo definido por suas opiniões, convicções e disposições, e não por sua posição no processo produtivo". Para Benjamin, o "lugar do intelectual na luta de classes só pode ser determinado, ou escolhido, em função de sua posição no processo produtivo".
} 
privilegiado Döblin com um $O$ Narrador como o fez com Leskov ${ }^{8}$. Imaginações apartadas, trataremos de Döblin não como um autor que precisaria de uma reavaliação da importância de seu trabalho, pois isso já não se faz mais necessário. Insistiremos mesmo é na possibilidade entrevista de que há certo paralelismo entre os romances de Alfred Döblin e Guimarães Rosa, e que as semelhanças e diferenças dos textos deles contribuem igualmente para que se entenda a experiência da modernidade e do discurso romanesco nela inserido.

Nosso primeiro passo neste trabalho será investigar alguns dos problemas suscitados em torno do romance enquanto discurso literário típico dos tempos modernos, privilegiando questões na tradição do chamado Bildungsroman (romance de formação ou educação); em seguida, partiremos para o tratamento específico que cada um dos dois romances deve receber, ou seja, uma análise do "döblinismo", para usar uma definição do próprio autor, e da "joãozice", ou "guimarãesrosice” do Grande Sertão: Veredas ${ }^{9}$. Nossa análise terá inicialmente como foco as trajetórias dos protagonistas Riobaldo e Franz Biberkopf, pretendendo na seqüência, como a linguagem dos dois romances, evidenciar os "tontos movimentos" que compõem os caminhos da narrativa e da vida modernas. Assim, almejamos fechar um todo coerente ao final de nosso trabalho, quando talvez consigamos inseri-los num conjunto mais abrangente que os situem em diálogo com questões tradicionais da forma romanesca, tal como o nosso recorte irá privilegiar. Caso nossa análise destes dois romances esclareça melhor em que medida podem os dois textos estar próximos, nosso objetivo terá sido atingido, e assim talvez aquela coleção de livros inicialmente imaginada não careça tanto de uma ordenação mais "sensata".

"Tudo é muito diferente do que imaginava o leitor ao tirar esse livro da estante", escreveu Walter Benjamin sobre o Berlin Alexanderplatz. Mas, e se nessa mesma estante

\footnotetext{
${ }^{8}$ Semelhante colocação encontramos em dois textos de Helmuth Kiesel. Cf. KIESEL, Helmuth. Geschichte der literarischen Moderne. Sprache - Ästhetik - Dichtung im zwanzigsten Jahrhundert. München: C. H. Beck, 2004, p. 356; KIESEL, Helmuth. Lesskow oder Döblin? Über die fragliche Grundlage der vielberufenen These von der Unmöglichkeit des Erzählens in der Moderne. In: Wirklichkeit der Kunst und das Abenteuer der Interpretation. Festschrift für Horst-Jürgen Gerigk. Klaus Manger (org.). Heidelberg: Winter, 1999, pp. 171-180.

9 Os dois termos, "joãozice" e "guimarãesrosice", não são invenções minhas, mas foram por mim encontrados nos manuscritos de Guimarães Rosa pertencentes ao IEB/USP. Cf. FJGR. MJGR - EO. Cx. 16, $01(49) .7 / 10$.
} 
estivesse também o Grande Sertão: Veredas presente, o que haveria de imaginar esse mesmo leitor? 
O que nos tranqüiliza é a seqüência simples, a reprodução da realidade avassaladora da vida numa seqüencia unidimensional, tal como diria um matemático; a ordenação, ao longo de um fio, de tudo quanto aconteceu no espaço e no tempo, precisamente aquele célebre 'fio da narrativa', que constitui afinal também o fio da vida. Felizes os que podem dizer 'quando', 'antes de' e 'depois de'! Mesmo vítima da maior desgraça ou debatendo-se com a dor, desde que sejam capazes de reproduzir os acontecimentos tal como se sucederam no tempo, sentem-se tão felizes como se estivessem no sétimo céu. É deste artifício que o romance tem tirado proveito: tanto faz que o viandante passeie a cavalo pela estrada sob chuva torrencial ou que arraste penosamente os pés na neve com vinte graus negativos, pois o leitor está numa situação confortável. Tal seria fácil de compreender se este truque da épica, com o qual já as amas sossegavam as crianças, a comprovada 'redução perspectivista do entendimento', não fizesse parte já da própria vida. $\mathrm{Na}$ relação de fundo consigo próprios os homens, na sua maioria, são narradores.

(Robert Musil, O Homem sem Qualidades)*.

* MUSIL, Robert. Der Mann ohne Eigenschaften. Reinbek bei Hamburg: Rowohlt Taschenbuch, 2004, p. 650. Ed. brasileira: O Homem sem Qualidades. Tradução de Lya Luft e Carlos Abbenseth. Rio de Janeiro: Nova Fronteira, 1989, p. 462. Optou-se aqui pela tradução portuguesa de Maria Lin Moniz integrante de Sobre o Romance no Século XX. A Reflexão dos Escritores Alemães. Teresa Seruya (org.). Lisboa: Edições Colibri, 1995, p. 48. 


\section{Problemas da forma romanesca}

Quando, entre 1936 e 1938, Mikhail Bakhtin se dedica ao estudo de uma tipologia histórica do romance que traçasse as linhas gerais de um seu desenvolvimento, algumas modalidades são categoricamente sugeridas: o romance de viagens (La Vida de Lazarillo de Tormes, o Gil Blas, do escritor francês Alain René Lesage etc.), o romance de provação da personagem (as hagiografias do início do cristianismo, por exemplo), o romance biográfico (biografias, autobiografias ou confissões, como em Agostinho) e o romance de educação (Erziehungsroman) ou Bildungsroman ${ }^{10}$. Justificadas as modalidades de romance escolhidas segundo princípios ordenadores da construção da personagem central, o Bildungsroman (e com ele Goethe) assume, para Bakhtin, a relevante tarefa de assimilação do tempo histórico "em todos os seus momentos essenciais"11. Destacando-se das outras modalidades e, de algum modo, incorporando-as também, o Bildungsroman está em seu texto associado à idéia de uma escrita capaz de compreender a "plenitude do tempo", sendo ela um presente, além de autônomo, composto das marcas de um passado e da projeção de um futuro. Assim, devido ao modo pelo qual configura os seus temas, Os Anos de Aprendizagem de Wilhelm Meister (Wilhelm Meisters Lehrjahre, 1795/1796) de Johann Wolfgang Goethe, paradigma da modalidade, é caracterizado por Bakhtin como um tipo "realista" de romance, pois nele se dá a representação dos "problemas da realidade e das possibilidades do homem, da liberdade e da necessidade, os problemas da iniciativa criadora" $" 12$ através de um olhar cuja sensível abrangência faz indissociáveis tempo e espaço - "cronótopo".

Aos parâmetros de uma sensibilidade historicamente situada na segunda metade do século XVIII, desvinculados que foram das convenções outrora sobre a estética artística atuantes, corresponde um característico discurso sobre a forma romanesca que, presente tanto em Bakhtin como já no tempo de Goethe (guardadas as diferenças que há entre as reflexões primeiras dos românticos e os estudos especulativos do teórico russo),

$\mathrm{T}^{10}$ Este estudo de Bakhtin, conhecido apenas em modo fragmentado, pode ser encontrado em língua portuguesa na tradução de Paulo Bezerra. BAKHTIN, Mikhail. O Romance de Educação e sua Importância na História do Realismo. In: Estética da Criação Verbal. 4ª ed. São Paulo: Martins Fontes, 2003, pp. 203258.

${ }^{11}$ Idem, ibidem, p. 223.

${ }^{12}$ Idem, ibidem, p. 222. 
faz notar a importância que a apreensão de uma assim denominada "totalidade da época", o que pode ser traduzido por uma complexa, multifacetada realidade, tem para o "gênero":

A grande forma épica (a grande epopéia), inclusive o romance, deve apresentar um quadro integral do mundo e da vida, deve refletir o mundo todo e a vida toda. No romance, o mundo todo e a vida toda são apresentados em um corte da totalidade da época. Os acontecimentos representados no romance devem abranger de certo modo toda a vida de uma época. Nessa capacidade de abranger o todo real está a sua essencialidade $\operatorname{artística~}^{13}$.

Como se nota, o "quadro integral do mundo e da vida" deve pertencer igualmente ao romance, um "corte da totalidade" de sua época, e à epopéia antiga, mas, não do mesmo modo, devemos acrescentar, pois, ainda com Bakhtin, verificamos que uma das particularidades do romance está na proximidade entre aquilo que é representado em seu enunciado e o "presente inacabado" da realidade em movimento que se encontra fora do livro, tempo que reúne os romancistas e os seus leitores, enquanto na epopéia antiga os acontecimentos heróicos são ambientados num passado distante e absoluto, sendo o "tempo antigo" hierárquico e axiológico, para o qual a memória divinizada (Mnemosýne), e não o conhecimento e a experiência individuais, como no romance, vem a ser o instrumento com o qual o aedo opera a função poética ${ }^{14}$. De uma evidente complexidade histórica, o processo pelo qual o tempo de um presente compartilhado substitui o passado axiológico nas diferentes formas de representação poética é bastante dinâmico. Apenas como esboço do problema, cabe notar que, de Homero aos trágicos Ésquilo, Sófocles e Eurípides, encontramos já uma significativa mudança, pois, se a ação trágica ainda está situada num tempo mítico, a sua função nos concursos em que eram representadas as peças já diz, todavia, algo de sua importância para a experiência dos espectadores ali presentes, valendo então o passado lendário e absoluto à "cura" de questões individuais

\footnotetext{
${ }^{13}$ Idem, ibidem, p. 246.

${ }^{14}$ Cf. BAKHTIN, Mikhail. Epos e Romance (Sobre a Metodologia do Estudo do Romance). In: Questões de Literatura e Estética. A Teoria do Romance. 5a ed. São Paulo: Editora UNESP/Hucitec, 2002, pp. 397428. V. tb. VERNANT, Jean-Pierre. Aspectos Míticos da Memória. In: Mito e Pensamento entre os Gregos. 2a ed. Rio de Janeiro: Paz e Terra, 2002, pp. 135-166.
} 
em seu tempo atuais, como assegura a Poética aristotélica $^{15}$. Nosso maior interesse aqui é porém mais restrito, e quer por ora somente observar que, entre a apreensão de uma "totalidade" histórica e a qualidade romanesca de almejar tal realização, surge a questão desse "presente inacabado" como problema fundamental, como veremos adiante com o desenvolvimento de nosso trabalho. Voltemos uma vez mais entretanto às questões suscitadas pela teoria bakhtiniana.

A escrita do romance, como demonstra Bakhtin, distingue-se historicamente de outras formas ficcionais por ser a de um "gênero por se constituir", quer dizer, uma prática em movimentação constante, contrastando assim com aquelas cujo cânone define modelos tradicionais mais precisos. Tal prática, em sua já comentada relação com o tempo histórico, apresenta em seus exemplares variados modos próprios para o dimensionamento temporal e espacial daquilo que é narrado, associando-se a isso as liberdades de suas feições plurilíngüe (encenação de vozes sociais e imaginários diversos) e parodística (naquilo que serve como tema e também naquilo que é incorporado ao texto em referências, empréstimos e apropriações das diversas tradições populares e eruditas $)^{16}$. Em cada uma de suas grandes realizações, a escrita múltipla do romance parece surpreender um modo particular de configurar um mundo próprio legítimo e legível, participante, em maior ou menor grau, das experiências de cada um de seus leitores.

Considerando aqui o interesse de Bakhtin no Bildungsroman para as suas observações sobre a totalidade de uma época que pode estar presente na escrita do romance, pensemos também nas discussões que circulavam nos dias de Goethe e de seus contemporâneos. Após a publicação de Wilhelm Meisters Lehrjahre, segue-se um intenso

\footnotetext{
${ }^{15}$ Deve aqui ser notado, também, mais um aspecto das diferenças entre os momentos antigo e moderno desta relação de um trabalho poético com o presente de suas relações e efeitos. Observa Luiz Costa Lima, por exemplo, que por "inconciliáveis que sejam os horizontes dos homens antigo e moderno, [...] a tragédia não deixa de ser uma 'obra do efeito' (ein Werk der Wirkung). Como, em nossos dias, a tragédia - ou a obra de arte, em geral - não está mais ligada ao calendário da polis, fazendo parte de suas celebrações, mas à experiência isolada do indivíduo, seu efeito já não mais pode ser entendido como purificação, efetuada no âmbito da festa cívica, de determinados afetos (piedade e terror)." Cf. LIMA, Luiz Costa. Mímesis: Desafio ao Pensamento. Rio de Janeiro: Civilização Brasileira, 2000, p. 44. V. tb. LIMA, Luiz Costa. Mímesis e Modernidade. Formas das Sombras. $2^{\mathrm{a}}$ ed. São Paulo: Paz e Terra, 2003, pp. 36-49.

${ }^{16}$ Cf. os dois textos de Bakhtin já citados (notas 10 e 14) e também: BAKHTIN, Mikhail. A Cultura Popular na Idade Média e no Renascimento. O Contexto de François Rabelais. $5^{\text {a }}$ ed. São Paulo: Hucitec/Annablume, 2002.
} 
debate sobre o livro ${ }^{17}$. Um de seus comentadores é Friedrich Schlegel (1772-1829), em quem se encontram tanto idéias em parte próximas àquelas de Bakhtin quanto também críticas singulares ao texto de Os Anos de Aprendizagem de Wilhelm Meister. Para Schlegel, o romance de Goethe deveria ser o paradigma poético, estético, moral e filosófico de sua época. No seu entendimento, em seus aspectos fundamentais a "poesia romântica" deveria ser "progressiva" e "universal"18. Isto é, Schlegel não aceita a existência de um limite histórico ou temático para a escrita ficcional, conferindo à tarefa de representação um sentido inesgotável e impossível, pois infinito, porém praticável. Evidencia-se assim que uma longa tradição de condicionamentos retórico-poéticos é então deixada de lado, interessando mais ao momento a competência individual de perceber e organizar uma realidade apreensível em diferentes níveis, cabendo ao "espírito orgânico"19 moldar o "universal", a totalidade do real num correspondente sistema poético, sendo o romance, "como a epopéia, um espelho do inteiro mundo circundante, um retrato da época" ${ }^{20}$.

O Wilhelm Meisters Lehrjahre conseguiu satisfazer às amplas exigências deste Schlegel apenas parcialmente. Considerado por ele uma das maiores tendências de seu tempo (ao lado da Revolução Francesa e da Doutrina da Ciência de Fichte) ${ }^{21}$, o Wilhelm Meisters Lehrjahre era para ele também um romance ainda um tanto incompleto e deficiente, pois, em suas palavras, um "romance perfeito deveria ser uma obra de arte muito mais romântica do que o Wilhelm Meister; mais moderna e mais antiga, mais filosófica, mais ética e mais poética, mais política, mais liberal, mais universal, mais social" ${ }^{22}$. O texto de Goethe, tanto para Schlegel quanto para Novalis, apesar de exemplar, foi considerado insatisfatório, e isso também diz respeito à maleabilidade do

17 Cf. o belo trabalho de Wilma Patricia Mas. MAAS, Wilma Patrícia. O Cânone Mínimo. O Bildungsroman na História da Literatura. São Paulo: Editora UNESP, 2000. Neste texto é possível encontrar desde algumas importantes referências à compreensão dos termos Bildung e Bildungsroman até uma breve, porém significativa abordagem da trajetória desses conceitos.

${ }^{18}$ Entenda-se aqui "poesia romântica" como romance, pois esta é uma das acepções do termo identificável em F. Schlegel. Refere-se aqui também à conhecida definição do fragmento 116 da revista Athenäum (1798): "Die romantische Poesie ist eine progressive Universalpoesie" ("A poesia romântica é uma poesia universal progressiva"). Cf. SCHLEGEL, Friedrich. Conversa sobre a Poesia e Outros Fragmentos. Tradução, prefácio e notas de Victor-Pierre Stirnimann. São Paulo: Iluminuras, 1994, pp. 98-99.

19 "O intelecto é mecânico. A espirituosidade (Witz) é química. O gênio é espírito orgânico". Idem, ibidem, p. 109.

${ }^{20}$ Idem, ibidem, p. 99.

${ }^{21}$ Cf. o fragmento 216 da Athenäum. Idem, ibidem, pp. 102-103.

${ }^{22}$ Este comentário de Schlegel foi colhido no livro de Wilma Patricia Maas. Cf. a nota 17. 
"gênero" romance, sugerindo a problemática de sua prática que lida com a ausência de fronteiras claras e por isso mesmo não põe termo às questões com as quais trabalha com o encerramento delas numa totalidade sem ruídos.

A distância entre nós e os textos de Goethe, Schlegel ou Novalis não elimina boa parte de suas questões então desenvolvidas, mas acrescenta ao problema alguns seus desdobramentos. Podemos localizar nesta segunda metade do século XVIII muito do nosso modo de pensar, ler ou escrever um romance (incluso nisso também os modos de produção, comercialização e circulação dos textos deste "gênero"). Assim reconhece Michel Foucault em sua análise epistemológica, quando afirmou que

[...] o pensamento que nos é contemporâneo e com o qual, queiramos ou não, pensamos, acha-se ainda muito dominado pela impossibilidade, trazida à luz por volta do fim do século XVIII, de fundar as sínteses no espaço da representação e pela obrigação correlativa, simultânea, mas logo dividida contra si mesma, de abrir o campo transcendental da subjetividade e de constituir inversamente, para além do objeto, esses “quase transcendentais" que são para nós a Vida, o Trabalho, a Linguagem ${ }^{23}$.

Leve-se em conta que a experiência e o conhecimento subjetivados a tal ponto fissuraram as bases das tradicionais práticas de representação (as premissas que outrora orientaram o trabalho poético, estabelecendo uma noção coletiva válida tanto para a produção quanto para a recepção e para a avaliação dos textos), abrindo um campo inteiramente novo para as relações entre ficção e realidade, sobre o qual o século XIX, sobretudo, pôde trabalhar as formas daquilo que talvez ainda hoje constitua a nossa idéia de "literatura". Sem deixar de mencionar que essas novas feições da linguagem estão intimamente relacionadas aos modos de produção capitalistas, ao declínio da autoridade real e da Igreja (e de suas relações com as artes), aos modos de vida mais livres, nos quais se desenvolveu com maior independência o pensamento científico, e a tudo aquilo que transformou processualmente o assim chamado "regime antigo" nesta política e vida modernas que hoje conhecemos, interessa aos limites de nosso trabalho o problema que atinge a forma romanesca, quando, reconhecida a sua paternidade na epopéia antiga, a

${ }^{23}$ FOUCAULT, Michel. As Palavras e as Coisas. Uma Arqueologia das Ciências Humanas. $8^{\mathrm{a}}$ ed. Tradução de Salma Tannus Muchail. São Paulo: Martins Fontes, 2002, p. 343. 
época em que ela definitivamente floresce traz em si uma espécie de impossibilidade de “fundar sínteses” no espaço da representação.

Para seguir o tema, há também em Georg Lukács o desenvolvimento de questões que nos tocam. Para ele, igualmente, o romance como herdeiro da epopéia clássica tem por finalidade encerrar uma certa "totalidade":

O romance é a epopéia de uma era para a qual a totalidade extensiva da vida não é mais dada de modo evidente, para a qual a imanência do sentido à vida tornou-se problemática, mas que ainda assim tem por intenção a totalidade ${ }^{24}$.

Mas também Lukács reconhece as diferenças entre os modos antigo e moderno de tal intenção. Em suas palavras, a "epopéia dá forma a uma totalidade de vida fechada a partir de si mesma", enquanto "o romance busca descobrir e construir, pela forma, a totalidade oculta da vida" ${ }^{, 25}$. Com isso, a escrita do romance pode ser caracterizada como um processo, um movimento em direção ao sentido que não lhe pertence a priori, mas que deve ser obtido no correr de sua narrativa. Assim, desde os primeiros autores modernos que identificamos nos românticos alemães como exemplo, o problema da "totalidade" a que visa o romance sofre da preponderância de um olhar subjetivo que da realidade colhe apenas fragmentos e organiza, a seu modo, uma composição que se quer plena de sentido. Retomaremos adiante a questão.

Já vimos antes com Bakhtin que o "idealista" e romântico Wilhelm Meisters Lehrjahre pode ser lido como um tipo "realista" de romance na representação dos "problemas da realidade e das possibilidades do homem" "26, mas quão menos "realista" seria a obra de Kafka, por exemplo, para um tempo em que o sujeito individual já não pode mais ser um elemento unificador e a centralidade do mundo senão um objeto sujeito às circunstâncias que lhe escapam ao entendimento? Deste modo, o "realismo" de um texto ficcional e o seu modo de representação da realidade só poderão ser compreendidos

\footnotetext{
${ }^{24}$ LUKÁCS, Georg. A Teoria do Romance. Tradução de José Marcos Mariani de Macedo. São Paulo: Duas Cidades; Ed. 34, 2000, p. 55.

${ }^{25}$ Idem, ibidem, p. 60.

${ }^{26} \mathrm{Cf}$. a nota 12 .
} 
se julgados de acordo com o contexto em que eles estão inseridos ${ }^{27}$. Quando Auerbach formula que o Wilhelm Meisters Lehrjahre é de longe o texto mais realista de Goethe, ele o faz com maiores restrições que Bakhtin. Para Auerbach o realismo de Goethe é ainda estreito, sua literatura não compreende "situações concretas de ordem política ou políticoeconômica" e as "reviravoltas contemporâneas na divisão social", tratando antes do "mundo da classe média" que "repousa diante dos olhos do leitor numa calma quase atemporal". Auerbach justifica tal situação nas condições de vida e na personalidade do próprio Goethe, alegando com isso "que Goethe nunca representou dinamicamente a realidade da vida social contemporânea, nunca como germe de situações futuras ou em estado de gestação" ${ }^{28}$. Sabe-se que durante a primeira metade do século XX essa preocupação com a representação da realidade sofreu o advento de posturas de teóricos marxistas mais radicais, como o mesmo Georg Lukács por nós já citado, que posteriormente à publicação de $A$ Teoria do Romance desenvolveu uma série de ensaios sobre o tema. A discussão do problema, que na literatura mais que um reflexo da realidade social não se valorizava, trouxe para a ordem do dia questões como a diferença entre o "narrar" e o "descrever" que poderiam ser identificadas nas escritas romanescas, sobretudo a partir de Balzac. Uma boa contribuição à discussão nessa ocasião foi dada por Bertolt Brecht, que, num texto de 1938, reflete de modo mais amplo o problema do realismo na literatura. Brecht defende que seria demasiado simplista atar o conceito "realismo" a alguns considerados romancistas burgueses e com isso determinar um padrão de escrita realista. Para Brecht, "o estilo realista só pode ser distinguido do nãorealista na medida em que é confrontado com a própria realidade da qual trata". Com grande sensatez, escreve Brecht que não "o conceito de estreiteza, mas o de amplitude combina com o realismo. A própria realidade é ampla, multifacetada, contraditória; a história cria e refuta modelos"29.

\footnotetext{
${ }^{27}$ Como afirma Luiz Costa Lima, a "ação da obra de Kafka é contemporânea a um tempo em que o controle do imaginário dispensa a idéia de verdade, sua elocubração filosófica ou religiosa, e torna esse controle o princípio de atuação das múltiplas agências do poder. Noutras palavras, a verdade deixa de ser afirmada a partir e em função de uma certa racionalidade, para que se confunda com o fato bruto de que certo poder quer, afirma e impõe tal coisa". Cf. LIMA, Luiz Costa. Limites da Voz - Kafka. Rio de Janeiro: Rocco, 1993, p. 184.

${ }^{28}$ AUERBACH, Erich. Mimesis. A Representação da Realidade na Literatura Ocidental. $4^{\mathrm{a}}$ ed. São Paulo: Perspectiva, 2002, pp. 399-404.

${ }^{29}$ BRECHT, Bertolt. Amplitude e Variedade do Modo de Escrever Realista. In: Estudos Avançados. № 34, v. 12, setembro/dezembro de 1998, pp. 267-276.
} 
Paradigmas do romance moderno do século XX, como Kafka, podem ser assim compreendidos no deslocamento do conceito "realismo" com a elasticidade que the é própria e a realidade que lhe condiz. Recordando aqui das nossas observações sobre a totalidade de uma época que deve ter lugar no romance e a existência de modos particulares pelos quais ela é procurada, podemos também trazer para o nosso texto esta observação de Michel Butor, para quem a "busca de novas formas romanescas cujo poder de integração seja maior representa pois um triplo papel com relação à consciência que temos do real: de denúncia, de exploração e de adaptação"30. Ora, a percepção que determinado escritor tem do mundo que o rodeia é de fato uma condição a ser explorada em sua escrita, a qual pode denunciar em sua linguagem uma realidade que é um certo efeito de realidade, pois resulta sobretudo de seu gesto criativo e das adaptações que the foram possíveis e desejadas por ser adequadas a um imaginário socialmente compartilhado. Nos desejos de um autor, é verdade, reside a subjetividade de um texto, mas é aí também que moram as qualidades dos grandes romancistas, pois neles surgem da relação de seus sentimentos individuais com os sentimentos tomados como gerais a sociabilidade e o sucesso da circulação de seus livros. O interessante nisso é que, como resultado de um bom trabalho de questões subjetivas, o texto do romance que assim se destaca acaba por verter aquilo que é da esfera pessoal do autor em algo que, modelado literariamente, supera o seu confinamento no indivíduo, como afirma Adorno:

De fato, os romances que hoje contam, aqueles em que a subjetividade liberada é levada por sua própria força de gravidade a converter-se em seu contrário, assemelham-se a epopéias negativas. São testemunhas de uma condição na qual o indivíduo liquida a si mesmo, convergindo com a situação pré-individual no modo como esta um dia pareceu endossar o mundo pleno de sentido ${ }^{31}$.

Num mundo abandonado à subjetividade dos homens, garantir na forma de representação do romance o sentido de um conjunto que se constrói a partir de uma realidade histórica tornada complexa, e que ainda assim tem por intenção abranger uma

\footnotetext{
${ }^{30}$ BUTOR, Michel. Repertório. São Paulo: Perspectiva, 1974, p. 11.

${ }^{31}$ Cf. ADORNO, Theodor W. Posição do Narrador no Romance Contemporâneo. In: Notas de Literatura I. Tradução de Jorge de Almeida. São Paulo: Duas Cidades; Ed. 34, 2003, p.62.
} 
certa totalidade, tendo por perto a transitoriedade de um "presente inacabado", como já observamos, não se faz sem problemas, e isso termina por exigir ao texto que assim está condicionado, em favor da vitalidade de suas idéias, experimentar modos narrativos estratégicos que intencionam dar conta dessa situação. Usualmente, o catalisador da problemática da forma romanesca encontra-se na situação do indivíduo que é eleito protagonista para em si suportar, de modo exemplar, os confrontos que emergem da exposição de determinada personalidade às circunstâncias externas que se lhe oferecem. Tais confrontos são, em grande medida, os responsáveis pela dose de realidade que despertam as leituras de romances, pois se não há nessa forma literária, como se acredita haver para a epopéia antiga, um sentido imanente à vida que já de antemão está dado, fazse necessário então que se construa algum, e isso apenas se dá através da forma biográfica que nos caminhos de um protagonista sugere o desenvolvimento de um sentido no embate entre os mundos interior e exterior dessa personagem.

Com maior ou menor êxito, os sentidos revelados pela trajetória de uma personagem que procura por algo são num romance logrados. Eles dependem, sobretudo, do aspecto temporal da narrativa que apresenta um "antes" e um "depois" de suas personagens. Dependem também da disposição que estes têm para a vida, já que a disparidade da realidade que permeia o enunciado do romance provavelmente será para eles no desenrolar do texto um motivo de maior ou menor resignação. A complexidade desse processo, que está situado na travessia que empreendem num texto um protagonista e as suas idéias, pode ser compreendida na forma romanesca através da inadequação existente entre as idéias da personagem privilegiada e a realidade que ali se apresenta mais ou menos tolerante em relação a elas. Foi também Georg Lukács, em seu livro já mencionado, que a partir de uma semelhante observação categorizou de forma distinta romances como o Dom Quixote, A Educação Sentimental e Os Anos de Aprendizagem de Wilhelm Meister. Dada a condição de um mundo disposto em fragmentos heterogêneos, o protagonista de um romance que se aventura por ele tem para Lukács em sua "alma" as condições básicas de duas disposições diferentes entre si: "a alma é mais estreita ou mais ampla que o mundo exterior que lhe é dado como palco e substrato de seus atos" ${ }^{32}$. No

\footnotetext{
${ }^{32}$ Cf. o livro citado na nota 24 , p. 99 . Bakhtin também afirma que "um dos principais temas interiores do romance é justamente o tema da inadequação de um personagem ao seu destino e à sua situação. $\mathrm{O}$ homem
} 
primeiro caso, está o por ele denominado "idealismo abstrato" do Dom Quixote, no qual o vigor ingênuo e a falta de problemática como dados interiores da personagem central fazem vir à tona a superioridade da realidade exterior com a qual ele se depara. No segundo caso, que tem maior interesse para o nosso trabalho, e por Lukács foi intitulado "romantismo da desilusão", é a "alma" do protagonista, "mais ampla e mais vasta que os destinos que a vida the é capaz de oferecer" ${ }^{\prime 3}$. Dessa discrepância, nasce a dificuldade de unificar os mundos interiores e exteriores, sem com isso concorrerem resignação e pessimismo sobrepostos à tentativa de uma vida satisfeita em seus ideais. O paradigma dessa forma romanesca é A Educação Sentimental de Gustave Flaubert. No mundo apresentado por esse romance, a convivência de valores desiguais que animam as tensões de sua narrativa não encontra o conforto de uma unidade que poderia, talvez, ser forjada artificialmente pelo protagonista Frédéric Moreau. Antes, sobressai uma série de frustrações que o convívio social demonstra ter a vida preparado para ele, como o fez para todos, e desse fracasso, como que tomado pela fatalidade, o protagonista reconhece que a plenitude da vida inclui em si as adversidades que tornam estéreis as suas lutas corporais e a boa vontade que o acompanharam.

Como um tipo romanesco localizado entre as duas formas que acima destacamos está Os Anos de Aprendizagem de Wilhelm Meister, o Bildungsroman, que para Lukács sintetiza as suas outras duas categorias ao reconciliar o "indivíduo problemático, guiado pelo ideal vivenciado, com a realidade social concreta" ${ }^{34}$. Sustentada pela trajetória de uma personagem central que também vê os seus desejos pessoais idealizados sucumbirem ao passo que a nudez dos fatos se apresentam, a forma desse romance, contudo, encontra uma via alternativa onde, transformados pela ação do tempo, fundem-se as realidades da "alma" do protagonista e do mundo que a rodeia:

Eis por que a interioridade aqui em apreço situa-se entre os dois tipos antes analisados: sua relação com o mundo transcendente das idéias é frouxa, tênue tanto subjetiva quanto objetivamente, mas a alma voltada puramente a si própria não integra $o$ seu mundo numa realidade que é ou deve ser perfeita em si mesma, que se opõe como

ou é superior ao seu destino ou é inferior à sua humanidade". Cf. o livro de Bakhtin citado na nota 14, p. 425 .

${ }^{33}$ Idem, ibidem, p. 117.

${ }^{34}$ Idem, ibidem, p. 138. 
postulado e poder rival à realidade externa, senão porta em si, como sinal do laço remoto embora ainda não rompido com a ordem transcendental, a aspiração a uma pátria no aquém que corresponda ao ideal - um ideal pouco claro no que aceita, inequívoco na rejeição. De um lado, portanto, essa interioridade é um idealismo mais amplo e que se tornou com isso mais brando, mais flexível e mais concreto e, de outro, uma expansão da alma que quer gozar a vida agindo, intervindo na realidade, e não contemplativamente. Assim, essa interioridade situa-se a meio caminho entre idealismo e Romantismo, e ao tentar em si uma síntese e superação de ambos, é rejeitada por ambos como transigência ${ }^{35}$.

Embora de forma bastante resumida, faz-se necessário ao nosso trabalho a atenção que demos aqui às categorias de Lukács para as análises que adiante terão lugar. Como formas romanescas que parecem transformar e intensificar os problemas dos tipos acima enfocados, leremos os romances de Guimarães Rosa e Alfred Döblin em suas particularidades.

A linguagem literária adquire no contexto do século XIX temas sem precedentes históricos, resultantes das novas condições de vida em que se encontraram, por exemplo, os indivíduos que viviam em capitais de um crescente e acelerado desenvolvimento industrial e econômico, como Londres ou Paris. Os problemas desse desenvolvimento urbano encontramos já na literatura de um Dickens ou de um Poe, caso fiquemos apenas com alguns dos exemplos que a prosa do período em questão pode oferecer. São do território londrino as imagens que se projetam de uma cidade pouco higiênica, rude e utilitária, como a Coketown do Hard Times de Dickens; e é o mesmo terreno londrino que serve de palco para as observações e caminhadas de um narrador de Poe em The Man of the Crowd, onde os modos e comportamentos de distintas classes e de um determinado indivíduo em meio ao movimento de uma multidão de passantes são detalhadamente analisados. Se aceitarmos, como aqui se quer fazer acreditar, que a experiência moderna está de muitas maneiras ligada à movimentação e à transitoriedade da vida dos centros urbanos, estaremos a firmar um acordo com o parisiense Baudelaire, para quem a “modernidade é o transitório, o efêmero, o contingente, é a metade da arte, sendo a outra

${ }^{35}$ Idem, ibidem, pp. 138-139. 
metade o eterno e o imutável" ${ }^{\prime 36}$. Adicionando a esse moderno modo de ler o mundo as posteriores experiências estéticas das vanguardas históricas (Expressionismo, Dadaísmo, Futurismo etc.), encontraremos a situação da linguagem verbal que se prestou a definir a poética da modernidade sobre o desmantelamento das representações clássicas. Em Baudelaire, o movimento e o transitório modernos ainda são apenas seus temas, mas nos futuristas e depois naqueles que em meados do século XX praticaram a poesia concreta, descendentes de Mallarmé que eram, fez-se do movimento o modo de escrever ele próprio, ocupando o movimento "da" palavra o lugar da palavra "sobre" o movimento. Mas quando e de que modo isso tudo afetaria a prosa do romance, que, por sua "natureza", não pode estar livre daqueles "antes de" e "depois de" que configuram uma representação do mundo no "fío da narrativa",37?

Certamente em James Joyce já é possível localizar, nos termos que desejamos, a moderna prosa do romance em sua plena realização. $\mathrm{O}$ uso que o autor irlandês faz em suas narrativas do chamado "monólogo interior" (stream of consciousness), das técnicas de montagem que assemelham construções cinematográficas numa narrativa não linear, assim como os profusos trabalhos que ele opera sobre o léxico da língua inglesa, resulta numa prosa exemplar do romance moderno. Ao lado dele, autores como os de nosso interesse, Guimarães Rosa e Alfred Döblin, foram mais de uma vez situados, já que técnicas narrativas similares às do autor irlandês foram por eles utilizadas. Encontra-se na prosa desses autores, como pretendemos demonstrar, uma movimentação constante que, além de caracterizar as vidas de seus protagonistas Riobaldo e Franz Biberkopf, habita de igual modo a superfície dos enunciados que as narram. Há nisso, devemos também notar, o suporte de um contexto histórico que se apresenta ao lado das representações literárias transformado, ou melhor, em transformação, pois "presente inacabado". No caso de Alfred Döblin, o espaço histórico que lhe serve de tema no Berlin Alexanderplatz, ou seja, a Praça Alex, como é conhecida, e o seu entorno, de 1925 a 1933, período que compreende a narrativa do livro, tem por qualidade a modernização de seus limites num intenso trânsito de pessoas, automóveis, bondes, mercadorias, informações etc. Esse período, que inclui ainda a implantação do metrô no local, bem como reformas estruturais

\footnotetext{
${ }^{36}$ BAUdelaire, Charles. O Pintor da Vida Moderna. In: Poesia e Prosa. Ivo Barroso (org.). Rio de Janeiro: Nova Aguilar, 1995, p. 859.

${ }^{37} \mathrm{Cf}$. a epígrafe deste trabalho.
} 
a cargo da moderna arquitetura de Martin Wagner, empresta à praça a condição de Weltstadtplatz $^{38}$. O livro de Döblin, para fazer jus à condição da praça, requer o trânsito da paisagem para si, como elemento constituinte de sua narrativa, valorizando a circulação do que ali se movimenta com a inclusão destes ambulantes em seu romance, que assim forja um texto "da" cidade, e não um texto "sobre" a cidade ${ }^{39}$. De modo similar, Guimarães Rosa empreende no seu Grande Sertão: Veredas uma espécie de texto “do" sertão, destacando-se assim de toda uma tradição brasileira de representações do espaço sertanejo, em cuja distância entre narrador e personagens desempenhavam-se narrativas que podem ser identificadas como textos "sobre" o sertão. Inserido nessa tradição que tratou literariamente as regiões do interior brasileiro, incluindo nisso nomes como José de Alencar, Euclides da Cunha, Coelho Neto, Simões Lopes Neto, Afonso Arinos de Melo Franco, e também contemporâneos seus como José Lins do Rego e Mário Palmério, distancia-se dela todavia o autor de Grande Sertão: Veredas por realizar no plano da linguagem a constituição de uma fala particular que se quer portadora da voz do sertão em si, como se fosse possível inverter os modos do tradicional olhar urbano em direção ao sertão através da invenção de um sentir e pensar sertanejos que encontrassem a sua realização na voz autoritária de Riobaldo, que no livro não permite outro falar, deixando mudo o seu interlocutor citadino. Porém, a "voz do sertão", que é Riobaldo, não se deixa convencer como tal sem maiores problemas, já que em sua falsa naturalidade ela é significativamente complexa, enxertando-se de leituras das representações cultas que já foram feitas do espaço sertanejo, além de abusar ricamente nos usos lingüísticos, o que acaba por configurar um discurso que só pode mesmo extrapolar os domínios de determinada região que seria, no caso, o sertão mineiro. Por conseguinte, a voz de Riobaldo, assim como o enunciado carregado de discursos heterogêneos do Berlin Alexanderplatz, é composta de outras vozes várias que ela faz falar, multiplexando um sem-número de significados a partir das operações que nela têm lugar ${ }^{40}$. Como já

\footnotetext{
${ }^{38}$ Cf. JOCHHEIM, Gernot. Der Berliner Alexanderplatz. Berlin: Ch. Links Verlag, 2006, pp. 128-151. Este recente livro compreende de modo significativo a história da praça desde os seus dias primeiros até à atualidade.

${ }^{39}$ Sobre o trânsito como parte constitutiva da paisagem no Berlin Alexanderplatz há o livro de Johannes Roskothen. Cf. ROSKOTHEN, Johannes. Verkehr. Zu einer poetischen Theorie der Moderne. München: Wilhelm Fink Verlag, 2003.

${ }^{40}$ Como linguagem literária que é, o texto do romance de Guimarães Rosa não deixa de ter implicações políticas quando na fala de Riobaldo podem ser notados "imaginários do intelectual organizador da cultura
} 
observou Bella Jozef, o "sertão roseano é um sertão enfaticamente significante, mas nunca completamente significado, num processo dinâmico que não nos fornece um sentido acabado. É um sertão polivalente, ambíguo, um sertão construído na linguagem" ${ }^{41}$. Sendo assim, em relação aos romances do século XIX que orientaram construções de categorias que os definem como as de Lukács por nós mencionadas, romances mais modernos como Grande: Sertão Veredas e Berlin Alexanderplatz trazem às questões de uma teoria da forma romanesca adicionais motivos, provenientes sobretudo da linguagem que neles narra uma certa situação de vida dos seus protagonistas e intensifica os desafios de "heróis" já outrora problemáticos, como são os casos das personagens dos livros A Educação Sentimental e Os Anos de Aprendizagem de Wilhelm Meister.

Ressaltamos até aqui em nosso trabalho com especial atenção o problema da "totalidade" que, como vimos, na forma de representação do romance encontra dimensões desconhecidas da epopéia clássica. Sem a intenção de concluirmos a questão, isso caso seja possível concluí-la, prosseguiremos em nossas observações sobre as linguagens dos dois livros que nos interessam, relacionando-as ao problema romanesco da compreensão numa narrativa de um certo "inteiro mundo circundante".

Talvez, poderíamos pensar, representar uma grande cidade ou um grande sertão possibilite a um discurso romanesco trabalhar com o múltiplo de um modo em parte facilitado, já que a amplitude dos espaços sertanejo e urbano é para qualquer um bastante vaga. Certamente, não se pode abranger por completo o que a totalidade de tamanhas dimensões guarda em si nas suas variadas esferas; essa pretensão escaparia a qualquer tipo de registro dos que conhecemos, já que eles são sempre em algum aspecto excludentes. Mas não é numa suposta "perfeição" de uma completude abrangida em seus distintos aspectos que exatamente reside a questão da "totalidade" no romance, e sim no alcance do recorte que é feito desta realidade integral, o que sem dúvida significa para o

que, com redes interpretativas, tentou cercar a metáfora 'Sertão' com flores e arame farpado", como observou João Adolfo Hansen. Cf. HANSEN, João Adolfo. Terceira Margem. In: Revista do Instituto de Estudos Brasileiros. N. ${ }^{\circ}$ 41. 1996, p. 58. Nesse texto, as questões aqui apenas mencionadas ganham seu devido desenvolvimento.

${ }^{41}$ Cf. JOZEF, Bella. O Romance Brasileiro e o Ibero-Americano na Atualidade. In: Guimarães Rosa. Eduardo F. Coutinho (org.). $2^{\text {a }}$ ed. Rio de Janeiro: Civilização Brasileira, 1991, p. 195. (Coleção Fortuna Crítica). 
entendimento moderno um conjunto multitudinário, vago e furtivo, e por isso mesmo escapa infinitamente ao passo que se queira compreendê-lo.

A cidade e o sertão são, para o romance, aquilo que o mar é para a antiga epopéia: um mundo de mistérios, sem porteiras nem fronteiras, com os quais se constroem narrativas que sobre a grandeza desses espaços crescem sem medida. Como já vimos, decorre disso que enunciados como os dos romances de Guimarães Rosa e de Alfred Döblin que operam nos seus textos a integração de idéias, imaginários e elementos discursivos vários entre si distantes, que fazem "falar" a cidade e o sertão, enquanto praticam uma mistura de constituintes diversos e desenrolam concomitantemente a história de seus protagonistas, atingem um ponto crítico que os situam nos limites da verossimilhança "habitual” da literatura. Citando Ettore Finazzi-Agró:

[...] em Grande sertão se dá, a meu ver, uma espécie de "imperfeição", no sentido já apontado de uma impossibilidade em marcar os limites (textuais e de gênero) desta obra, em que, de fato, a consciência da partição e da heterogeneidade convive com o desejo de uma representação global [...] Grande sertão vale justamente pelo muito que nele deveu (isto é, que o autor achou que nele devia) caber. E esse "valor" só podia ser alcançado, de fato, através de uma mistura de gêneros e de discursos, somente graças àquele excesso, àquela extravagância, que nos entrega a obra na sua "imperfeição": produto de uma contaminação infinita, em que se reflete um mundo (histórico, social, ético...) cheio de verdades contaminadas, de misturas entre as coisas; Grande sertão é imperfeito na medida em que tenta representar uma realidade em que a perfeição é apenas uma ilusão ótica, é apenas o fruto precário de uma decisão, de um ato de força, de um determinismo oco ${ }^{42}$.

Como portadores de um discurso farto em referências históricas, presenças míticas, situações políticas, morais e personagens vários que se ligam com maior ou menor relevância às histórias de seus protagonistas, Grande Sertão: Veredas e Berlin Alexanderplatz, para realizarem algo que se sustente como um recorte satisfatório de uma certa "totalidade" do real, ao desenvolverem as histórias de seus personagens centrais,

\footnotetext{
${ }^{42}$ Cf. FINAZZI-AGRÓ, Ettore. Um Lugar do Tamanho do Mundo. Tempos e Espaços da Ficção em João Guimarães Rosa. Belo Horizonte: Editora UFMG, 2001, pp. 34-35.
} 
usam de modos narrativos que em si parecem permitir que de tudo neles seja incluso. Nessa "vontade enciclopédica" dos dois romances, revela-se uma forma narrativa estratégica, um "hiper-narrador inclusivo", como notou João Adolfo Hansen para o caso do estilo que é Riobaldo ${ }^{43}$, com uma definição que poderia ser igualmente aplicada à narrativa inclusiva do romance de Döblin.

O Berlin Alexanderplatz, como o livro de Rosa, é também de uma narrativa "contaminada", um texto que parece ser incapaz de excluir qualquer elemento discursivo que imaginemos poder participar da vida de uma metrópole. Nele, procura-se abraçar a pluralidade urbana com todos os seus conflitos e contradições, como se nota quando a sua narrativa caminha com o encadeamento de discursos heterogêneos que se ligam sem uma aparente afeição mútua. Intimidar-se com a disparidade dos elementos que circulam no espaço urbano não é para o romance de Döblin, sendo ele dono de um enunciado que, ao menos potencialmente, tudo parece poder comportar.

Ao que indica a teoria de Bakhtin, é imperativo que o romance lide em seu discurso com este potencial plurilingüístico, ou seja, com uma quantidade diversificada de vozes que dramatizam nele um leque de formações imaginárias, temporais, lingüísticas etc. No romance "devem ser representadas todas as vozes sócio-ideológicas da época, ou seja, todas as linguagens, qualquer seja a sua importância; o romance deve ser o microcosmo do plurilingüismo", afirma o teórico russo. Com a feição de um problema inerente ao gênero, esta encenação de plurais formações em convivência íntima, apesar de seus aspectos distintivos, no romance moderno conhece textos como os de Guimarães Rosa e de Döblin, que têm discursos enriquecidos no diverso que visa uma "totalidade".

Nessa abrangência dos discursos do Grande Sertão: Veredas e do Berlin Alexanderplatz, embora seja tocado o problema do recorte de uma "totalidade", atinge-se do mesmo modo um significativo conflito, próprio da qualidade desta forma de representação que os caracteriza. Quanto mais se aproximam esses textos de uma certa "totalidade" mediante o crescimento de suas narrativas que se recheiam sem restrições, mais se compromete neles o sentido de uma unidade que se quer construída a partir

\footnotetext{
${ }^{43}$ Cf. HANSEN, João Adolfo. O O. A Ficção da Literatura em Grande Sertão: Veredas. São Paulo: Hedra, 2000 , p. 23.
} 
daquele outro aspecto romanesco que, como já mencionamos, responde também pela constituição dessa "totalidade", isto é, o desenvolvimento das trajetórias de seus protagonistas. Próximos como heteróclitos, os romances de Guimarães Rosa e de Alfred Döblin, ao trabalharem com uma variedade de discursos distantes reunidos em uma única narrativa que apresenta a polêmica e o contraste de formações imaginárias de temporalidades diversas, dissolvem o elemento orgânico que nos romances do século XIX, ou no Wilhelm Meisters Lehrjahre, como vimos, integra protagonista e o seu entorno numa unidade de sentido ficcional tomada exemplarmente por "totalidade". Riobaldo e Franz Biberkopf, caso sejam a redução de toda a vida de uma época, não chegam todavia a unificar o sertão e a cidade, mas posicionam-se como agentes nos quais registros vários são dramatizados e assim produzem uma constante indeterminação, corroborada incansavelmente pelo que se pode apreender de seus "anos de aprendizagem".

Em nosso trabalho, procuraremos definir as experiências de Riobaldo e de Franz Biberkopf a partir da análise de pontos de suas trajetórias particulares. Adiantamos, por ora, que será o caráter transitório de suas vidas que mais nos interessará na escolha desses pontos. Entendemos com isso, acrescente-se, que na movimentação dos protagonistas de nosso interesse reside um elemento esclarecedor desta especificidade moderna dos romances aqui focados. Pretendemos ainda, com o desenvolvimento de nosso texto, identificar a presença de tal movimentação em outros níveis, antes de concluir. 


\section{Berlin Alexanderplatz e Grande Sertão: Veredas}

I. Berlin Alexanderplatz, publicado em 1929, acumula, assim como o Grande Sertão: Veredas, uma numerosa quantidade de interpretações; suas leituras elegem-no um dos mais notáveis romances do século XX, sobretudo quando os temas em questão são o espaço urbano e a vida de seus habitantes socialmente marginalizados e seu entorno caótico e transtornado.

Vistos tradicionalmente como campos propícios à multiplicidade, os centros urbanos encontram no discurso literário do romance um justo correspondente. Dotado de uma complexa narrativa, o Berlin Alexanderplatz inclui em seu texto os mais variados elementos discursivos que perturbam o cotidiano movimentado da vida urbana. Como cedo observou Walter Benjamin, o espaço que rege a vida do protagonista Franz Biberkopf não é muito amplo, atinge no máximo um raio de mil metros ${ }^{44}$, mas o limite geográfico do espaço histórico representado sofre neste romance de uma evidente expansão, tornando-se antes uma espécie de espaço sem limites, pois o discurso do Berlin Alexanderplatz funciona de tal forma que inúmeras associações lhe são possíveis, deixando vagos os seus contornos.

Assim, a trajetória de Franz Biberkopf, com seus empregos precários, seu envolvimento com criminosos, seus relacionamentos amorosos e amizades duvidosas, seus acidentes de percurso e seu limite intelectual que lhe restringe as opções, é acompanhada daqueles variados elementos discursivos que compõem o circular cotidiano de informações de uma grande cidade: as notícias dos veículos de massa, os discursos políticos, as propagandas dos produtos em mercado, a sonoridade do trânsito de veículos etc., tudo justaposto numa organização de efeito descontínuo, paratática, em que os discursos que a compõem são nivelados numa única superfície, tornando próximos e paralelos registros tão desiguais quanto trechos bíblicos e conversas de uma mesa de bar sobre política, referências históricas e alusões míticas, observações de um narrador e pensamentos dos personagens etc.

Não existe no Berlin Alexanderplatz um discurso soberano que não se sinta perturbado por discursos de um entorno, distinguindo nesse aspecto a sua representação

\footnotetext{
${ }^{44}$ Cf. o texto de Benjamin citado na nota 6, p. 58 da edição brasileira.
} 
da cidade dos tempos modernos daquela que podemos encontrar em um filme como Die Sinfonie der Großstadt (1927), de Walther Ruttmann, que, em sua técnica de montagem também sistematizada, faz da cidade um espaço sob a organização de um tempo linear no qual são integrados harmonicamente distintos aspectos sociais, políticos e culturais, fazendo-se ausente a disparidade das convivências conflitantes.

Observe-se que, por exemplo, num pequeno trecho da narrativa do Berlin Alexanderplatz, no primeiro capítulo do quarto livro, pode ser lida, como quem com bons olhos e ouvidos caminhasse, toda a ambiência da praça que intitula o romance no seu trânsito de pessoas e bondes, com seus trabalhadores da construção civil, ruas que lhe circundam ocupadas de prédios simultaneamente comerciais e residenciais; e, prosseguindo, tem-se o próprio comércio dali enumerado: "comes e bebes, venda de frutas e legumes, especiarias e mercearias finas, empresa de transportes, decoração e pintura" etc. $(B A, t p, \text { p. } 127)^{45}$, que se encontra interrompido por propagandas de uma sedução barata e violenta:

- O seu coração vai pular! O seu coração vai pular de alegria quando possuir um lar equipado com as famosas Höffner. Todos os seus sonhos de conforto e ambiente agradável vêem-se agora superados por uma realidade nunca antes imaginada. Poderão os anos ir passando, que esta visão se manterá fonte de prazer, e a sua durabilidade e aplicabilidade prática terão encanto sempre renovado $\left(B A, t p\right.$, p.128) ${ }^{46}$.

Publicidade, um discurso político que entrecorta, dados comerciais, novamente publicidade e, seguindo assim, chega a narrativa do Berlin Alexanderplatz às residências da região e visitamos o prédio em que finalmente encontramos o nosso protagonista

\footnotetext{
${ }^{45}$ A edição do Berlin Alexanderplatz aqui utilizada é a seguinte: DÖBLIN, Alfred. Berlin Alexanderplatz. Die Geschichte vom Franz Biberkopf. Frankfurt am Main: Suhrkamp, 2002. Durante o nosso texto ela sempre será citada com a sigla BA. Ed. brasileira: DÖBLIN, Alfred. Berlim Alexanderplatz. A História de Franz Biberkopf. Tradução de Lya Luft. Rio de Janeiro: Rocco, 1995. Ed. portuguesa: DÖBLIN, Alfred. Berlim Alexanderplatz. A História de Franz Biberkopf. Tradução de Sara Seruya e Teresa Seruya. Lisboa: Dom Quixote, 1992. As siglas $t b$ e $t p$ nas citações valem respectivamente para as traduções brasileira e portuguesa. A partir deste momento, incluiremos em nosso trabalho o texto original em língua alemã das citações que faremos uso em traduções do romance.

46 “- Ihr Herz lacht! Ihr Herz lacht vor Freude, wenn Sie ein mit den berühmten Höffner-Möbeln ausgestattetes Heim besitzen. Alles, was Sie sich an angenehmer Wohnlichkeit erträumten, wird von einer ungeahnten Wirklichkeit übertroffen. Wie auch die Jahre entschwinden, wohlgefällig bleibt dieser Anblick, und ihre Haltbarkeit und praktische Verwendbarkeit erfreuen immer von neuem" (BA, pp. 131-132).
} 
Franz Biberkopf, "depois do desaguisado com Lüders", mas, antes que o texto o alcance, visitamos todos os andares e acompanhamos um pouco da vida de cada um dos moradores desse prédio: um advogado no primeiro andar, o administrador e "dois corpulentos casais" no segundo andar, um polidor de móveis no terceiro andar etc. ( $B A$, tp, pp. 129-132). Suspenso que estava Franz Biberkopf, ele apenas deixa de estar ausente no capítulo seguinte (BA, tp, pp. 132-135), quando reaparece nosso protagonista em meio a uma profunda crise cuja descrição inclui as palavras de um narrador, pensamentos desgovernados de Biberkopf, que em sua cama passeia e conversa com uma aranha no teto do quarto dependurada, além de referências religiosas e históricas (Karl Liebknecht e Rosa Luxemburg, Jugendbewegung etc.).

A constante inconstância no alternar de discursos configura a narrativa do Berlin Alexanderplatz, e nisso tudo mal se sustenta Franz Biberkopf, "um gigante infantil e desamparado, perdido no remoinho da cidade", como notou já Anatol Rosenfeld em 1959 , num primeiro texto sobre o livro e seu autor publicado no Brasil ${ }^{47}$.

Uma personagem como Franz Biberkopf, para quem faltam iniciativas, fez com que a primeira crítica do Berlin Alexanderplatz fosse bem dividida. Se Walter Benjamin num primeiro momento parece elogiar o livro de Döblin, contemporaneamente, em 1930, artigos de escritores comunistas, como Johannes Becher, apresentam num tom mais irritado os "problemas" políticos e literários do livro. Para Becher, o trabalhador dos transportes Biberkopf é um artificial "produto de laboratório", não o "consciente representante de uma classe", como deveria ser um "verdadeiro" trabalhador dos transportes ${ }^{48}$. Franz Biberkopf não toma partido; quando anda, anda de fato em cima de muros. Os leitores da publicação Linkskurve reclamam quando, também em 1930, uma editora de Moscou prepara a publicação do Berlin Alexanderplatz na União Soviética; o Escritório Internacional para Literatura Revolucionária alega que Döblin não tem o

${ }^{47}$ ROSENFELD, Anatol. A Confusão de Babel: Alfred Döblin. In: Letras Germânicas. São Paulo: Perspectiva; Edusp; EdUNICAMP, 1993, pp. 168. (Artigo publicado inicialmente no Suplemento Literário de $O$ Estado de S. Paulo, em 28 de fevereiro de 1959).

${ }^{48}$ Cf. BECHER, Johannes R.. Einen Schritt weiter! In: Materialien zu Alfred Döblin Berlin Alexanderplatz. Matthias Prangel (org.). Frankfurt am Main: Suhrkamp, 1975, p. 93. 
direito de ser lido pelos trabalhadores soviéticos ${ }^{49}$. Para outro autor que publica nesse mesmo órgão em 1929, Döblin se declarou um inimigo da organizada luta de classes do proletariado ao publicar o Berlin Alexanderplatz ${ }^{50}$. Quer dizer: àqueles que a literatura tem a sua validade dentro de um programa político que lhe determina uma função específica, o Berlin Alexanderplatz parece não haver agradado.

Rico em sua narrativa, o romance de Döblin não poderia mesmo ajustar-se às estreitas exigências políticas de alguns de seus leitores. Antes, o Berlin Alexanderplatz demonstrou, desde a sua publicação, a capacidade de projetar um amplo leque de interpretações e uma variedade enorme de reações entre os extremos dos que negavam ou festejavam o seu aparecimento. Com uma técnica narrativa que o aproxima das montagens cinematográficas, Berlin Alexanderplatz surpreendeu a sua época, polemizando o seu lugar histórico para os que tinham a estética literária como principal objeto de estudo, e alimentando os que na literatura procuravam suas relações com a vida e valores representados, pois o livro de Döblin, tal qual o Grande Sertão: Veredas, pode proliferar significados ao gosto de seus leitores, dependendo das intenções de quem o quer compreender.

Como romances polêmicos, que dividiram as opiniões daqueles que os tomaram como críticos, os romances de Döblin e Guimarães Rosa poderiam já estar próximos, como veremos em seguida ao abordar o Grande Sertão: Veredas ${ }^{51}$.

\footnotetext{
${ }^{49}$ Cf. a reprodução deste texto também em: Materialien zu Alfred Döblin Berlin Alexanderplatz. Matthias Prangel (org.). Frankfurt am Main: Suhrkamp, 1975, p. 100.

${ }^{50}$ NEUKRANTZ, Klaus. Berlin Alexanderplatz. In: Materialien zu Alfred Döblin Berlin Alexanderplatz. Matthias Prangel (org.). Frankfurt am Main: Suhrkamp, 1975, p. 87.

${ }^{51}$ De passagem, note-se que em outros aspectos, valeria também investir numa aproximação do livro de Döblin com textos de outros autores brasileiros, como, por exemplo, aquele Paulinho Perna Torta, de João António, onde são narradas as "perambulagens" da trajetória de um marginal de fama na barafunda do centro paulistano. Outra comparação interessante estaria no Berlin Alexanderplatz com Os Ratos, de Dyonelio Machado, no qual o protagonista Naziazeno enfrenta problemas de uma esfera social pouco privilegiada numa linguagem que funde, ao modo de Döblin, os pensamentos de um narrador e da personagem central.
} 
II.

Cultivar o deserto como um pomar às avessas. (João Cabral de Melo Neto, Psicologia da Composição)*.

Desde sua publicação em 1956, o Grande Sertão: Veredas de Guimarães Rosa tem incentivado uma considerável quantidade de interpretações, constituindo hoje tais leituras uma extensa fortuna crítica que, bastante diversificada, ora ressalta as qualidades estéticas do romance, ora o compreende numa determinada situação histórica; ora the encontra traços políticos, ora the extrai sentidos metafísicos, sem que, ao privilegiar um aspecto específico do livro, necessariamente seu intérprete negue ou ignore as suas outras qualidades.

Já as primeiras reações ao Grande Sertão: Veredas foram as mais distintas, revelando cedo alguns admiradores incondicionais entre uns outros que recusavam sua grandeza. Os cadernos ou seções de literatura de jornais e revistas de então promoviam debates, colhiam posturas divergentes e acentuavam como polêmica a situação do romance emergente. É de se notar com alguma curiosidade, por exemplo, um anúncio de uma livraria de São Paulo, publicado na Folha da Manhã, em 22 de julho de 1956, poucos dias após o lançamento do livro de Guimarães Rosa ${ }^{52}$. O anúncio qualifica Grande Sertão: Veredas como "um livro diferente, terrível, consolador e estranho". Muito provavelmente, poucas outras vezes um adjetivo como "estranho" deve haver sido utilizado em uma propaganda que pretende comercializar um romance. Pode ser que a dificuldade que o livro impôs às costumeiras classificações é que tenha incentivado tal ocorrência, que, justifica-se com alguma razão, pois mesmo em relação ao Sagarana, primeiro livro de Guimarães Rosa, Grande Sertão: Veredas estava distante, e mais afastado ainda ele estava dos romances regionalistas típicos (se bem existe um regionalismo típico), tratando-se mesmo de um estrangeiro em seu contexto; um estrangeiro cuja língua, ao entendimento de muitos ainda desafiava.

As perplexidades em relação ao Grande Sertão: Veredas, além de extensas, são bastante interessantes. Um comentário que talvez mereça atenção é o de Nelson Werneck

\footnotetext{
* MELO NETO, João Cabral de. Psicologia da Composição. In: Obra Completa. Rio de Janeiro: Nova Aguilar, 1994, p. 96.

${ }_{52}$ Documento encontrado no Fundo João Guimarães Rosa do IEB/USP. Cf. MPJGR - S/JGR. R4, 13, p. 4.
} 
Sodré, que em artigo de 16 de novembro de 1956, reclama verossimilhança ao texto de Guimarães Rosa, acusando-o de cometer o mesmo erro de escritores como Taunay, Arinos, Waldomiro Silveira, Alcides Maya e Coelho Neto, ou seja, traduzir "pitorescamente" o espaço sertanejo. Escreve Sodré:

Traduzir o sertanejo em linguagem erudita, fazer do sertanismo a base de uma tentativa de renovação do idioma, como sr. Guimarães Rosa pretendeu, é completar o falso antigo com nova notação. A linguagem do autor, no caso, nem é a dos dicionários e nem a do povo. A falsidade na forma corresponde à falsidade no fundo, no conteúdo. Tal falsidade traduz-se na ausência de comunicação na obra: não a entendem os leitores comuns, não a entendem os homens de letras. Ora, onde e quando os motivos populares foram traduzidos assim, de sorte a não serem entendidos por pares e ímpares? Obscuro, falso nos ambientes e falso nas personagens, o sr. Guimarães Rosa aparece como um gênio incompreendido, só acessível a alguns, os iniciados, os predestinados ${ }^{53}$.

Notável nesse comentário de Sodré, desconsiderando seus argumentos que pedem para um texto literário refletir com fidelidade a realidade correlata que ele concebe, é que um ponto fundamental do Grande Sertão: Veredas é tocado: a falsidade. "O Guimarães Rosa quer que todo mundo faça pirâmide e não biscoito. Mas o que é a obra do Guimarães Rosa senão uma pirâmide de confeitaria?", declarou certa vez Nelson Rodrigues ${ }^{54}$.

Ora, é mesmo surpreendente a fala de Riobaldo, que tanto recorda e reflete ao "ordenar" sua vida num monólogo incessante de mais de 500 páginas cujo ousado léxico faz uso da oralidade sertaneja, de eruditismos, latinismos, arcaísmos, neologismos, estrangeirismos etc. "O senhor me organiza?", pergunta Riobaldo (GSV, p. 345). Monumental, Grande Sertão: Veredas não permite que seus contornos sejam facilmente identificados.

Coincidem aproximados na fala de Riobaldo elementos diversos que se apresentam numa linguagem rica em delicadezas poéticas, produzindo a todo momento um estado de indeterminação que atinge o seu leitor de diversas maneiras. Já em 1957

${ }^{53}$ SODRÉ, Nelson Werneck. Um Caso Singular. Artigo publicado nas Notas de Crítica do jornal Última Hora de São Paulo, em 16 de novembro de 1956. Cf. FJGR. MPJGR - S/JGR. R4, 96, p. 57.

${ }^{54}$ Cf. RODRIGUES, Nelson. Flor de Obsessão. São Paulo: Companhia das Letras, 1997, p. 78. 
afirmava Antonio Candido que na "extraordinária obra-prima Grande Sertão: Veredas há de tudo para quem souber ler, e nela tudo é forte, belo, impecavelmente realizado" ${ }^{\circ 5}$.

Pode ser, por conseguinte, que a tarefa mais interessante para a crítica do Grande Sertão: Veredas seja a de desvendar seu mecanismo, e com isso entender de que modo ele é capaz de produzir as variadas leituras que o tomam como objeto. Também específico, esse modo de ler o romance tem no livro de João Adolfo Hansen um belo exemplar. Analisando os "procedimentos retóricos" de Guimarães Rosa, Hansen investiga o texto do romance como dispositivo capaz de projetar em seus leitores, através de suas recategorizações e reclassificações lingüísticas que produzem "efeitos de essências e reminiscências", interpretações que o tomam como "platonismo da mímese, livro de sociologia, exemplificação psicanalítica, estudo gramatical e lingüístico, análise estrutural e análise estruturalista, ilustração semiótica, ajustes de conta com a Verdade do realismo socialista, cantigas de comover de amigos, declaração de amor e de ódio, filme, romance fluvial sem fim joyceano, partilhas acadêmicas, assunção vanguardista" etc ${ }^{56}$.

Também o livro de Willi Bolle, mais recente, auxilia quando procura classificar as diferentes correntes que se encontram dentro da fortuna critica de Grande Sertão: Veredas. Para Bolle são cinco os principais "tipos metodológicos": os estudos lingüísticos e estilísticos; as análises de estrutura, composição e gênero; a crítica genética, dedicada a esclarecer o processo de elaboração do texto; as interpretações esotéricas, mitológicas e metafísicas; e, por fim, as interpretações sociológicas, históricas e políticas, dentro das quais ele se inclui ${ }^{57}$.

Imerso nessa considerável gama de leituras, nossa abordagem do romance de Guimarães Rosa procura sua especificidade ao rastrear a trajetória da personagem Riobaldo, narrador, em seus "anos de aprendizagem" e na "educação de seus sentimentos". De certo modo, podemos afirmar que isso nos levaria a participar das análises de estrutura, composição e gênero, de acordo com as definições de Willi Bolle. Ao ler contudo os caminhos de Riobaldo, procuraremos alcançar também através dele outros aspectos do livro, como, por exemplo, o caráter transitório dos elementos de sua

\footnotetext{
${ }^{55}$ CANDIDO, Antonio. O Homem dos Avessos. In: Tese e Antítese. $4^{\text {a }}$ ed. São Paulo: T. A. Queiroz, 2000, p. 121.

${ }^{56}$ Cf. o livro de Hansen citado na nota 43.

${ }^{57}$ Cf. BOLLE, Willi. Grandesertão.br. O Romance de Formação do Brasil. São Paulo: Duas Cidades; Ed. 34, 2004, pp. 19-20.
} 
narrativa que, para nós, deve dizer algo em relação à composição do texto de Guimarães Rosa como problematização de seus significados e questões romanescas.

Assim como faremos com o Grande Sertão: Veredas, teremos em seguida, como ponto de partida em nossa análise do Berlin Alexanderplatz, uma leitura da trajetória de seu protagonista, trilhando o caminho aberto por Walter Benjamin quando ele associou a vida de Franz Biberkopf à de Frédéric Moreau de A Educação Sentimental. Claro está para nós que acompanhar apenas as andanças e transformações sofridas por Franz Biberkopf é ocupar-se de somente uma parte do romance, visto, como observamos, que o Berlin Alexanderplatz compõe-se ainda de muitos outros elementos que são os tantos anônimos que circulam junto aos acontecimentos vários que compõem um cotidiano de uma grande cidade. Todavia, será através do percurso do protagonista que abriremos nossa análise para a aproximação que desejamos com o romance de Guimarães Rosa, quando procuraremos ampliar o nosso trabalho com um tratamento mais abrangente dos dois romances. 


\section{Andeja vida: Riobaldo}

I.

Porque aprender-a-viver é que é o viver, mesmo. (GSV, p. 550).

Percorrer a trajetória de Riobaldo significa acompanhar um ir e vir que, tão movente quanto sua fala e extenso quanto sua memória, pouco fixa e mais se assemelha ao inacabado de um devir que emerge dos pedaços que constituem o narrar de sua existência. Espalhados no texto numa ordenação muito própria, os fragmentos que compõem o fluxo narrativo ininterrupto que conta a vida do jagunço Riobaldo são orientados por um modo retrospectivo de narrar e acompanhados das incessantes interferências reflexivas do narrador que julga seu passado com os olhos do presente. Organizar os acontecimentos narrados por Riobaldo de modo linear, porém, seria tarefa insuficiente para quem, como nós, pretende ler sua trajetória. "Contar seguido, alinhavado, só mesmo sendo as coisas de rasa importância" (GSV, p. 95). A sucessão dos fatos narrados, tal como se encontram no livro, muito importa, pois obedece aos sentimentos do protagonista que recorda e especula, percorrendo assim a enunciação do Grande Sertão: Veredas os caminhos da memória e do entendimento de Riobaldo, que, afetivos, escolhem quais os momentos de sua vida devem ser notados como cruciais e destacados, assim como insinuam de que modo podem eles ser compreendidos.

Ficcional, é certo que a fala de Riobaldo opera suas decisões como lembranças que, submetidas às vontades reflexivas e lexicais do presente do narrador, revelam sua arbitrariedade. "Assim eu acho, assim é que eu conto" ( $G S V$, p. 95). De qualquer forma, uma trajetória se faz notar, com fatos que se sucedem no texto, e seu narrador, Riobaldo, é quem reconhece e nos faz reconhecer que mudanças em sua vida houve, muitas, entre um antes, passado que é lembrado, e um depois, presente da narrativa e de suas leituras que lembra:

De primeiro, eu fazia e mexia, e pensar não pensava. Não possuía os prazos. Vivi puxando difícil de difícel, peixe vivo no moquém: quem mói no asp'ro, não fantasêia. Mas, agora, feita a folga que me vem, e sem pequenos dessossêgos, estou de range rêde. E me inventei neste gosto, de especular idéia (GSV, p. 11). 
Especulando, sem deixar as fantasias de lado, Riobaldo recorda sua infância de menino pobre, e também seus saudosos anos de estudos, no Curralinho, que, de certo modo, justificam também sua capacidade atual de reflexão, pois não fora ele privado de toda educação, sendo homem letrado que ainda no presente cultiva o hábito de ler:

Soletrei, anos e meio, meante cartilha, memória e palmatória. Tive mestre, Mestre Lucas, no Curralinho, decorei gramática, as operações, regra-de-três, até geografia e estudo pátrio. Em folhas grandes de papel, com capricho tracei bonitos mapas. Ah, não é por falar: mas, desde o começo, me achavam sofismado de ladino. E que eu merecia de ir para cursar latim, em Aula Régia - que também diziam. Tempo saudoso! Inda hoje, apreceio um bom livro, despaçado (GSV, p. 15).

Fatos que remetem o leitor à juventude de Riobaldo, como esses anos no Curralinho, são visitas de um Riobaldo velho a um tempo já distante, que ele no presente de sua narrativa recorda como jagunço aposentado, casado, proprietário, religioso, e de tudo muito desconfiado. "Mocidade. Mas mocidade é tarefa para mais tarde se desmentir" (GSV, p. 24). O intervalo que separa o acontecido do presente da narrativa contraria Riobaldo, atrapalha-o, pois mesmo as melhores e mais distantes lembranças podem ser aborrecidas pelos acontecimentos que viriam em seguida e que lhe marcaram com grande significação. "Eh, de primeiro meu coração sabia bater copiando tudo. Hoje eu desconheço o arruído rumor das pancadas dele" (GSV, p. 81). O Riobaldo saudoso que traz ao leitor suas mais longínquas recordações não o faz sem conhecer a seqüência de fatos que marcaram sua vida como um todo, portanto, em seu presente de narrador, tal conhecimento influi em sua leitura, balanço que atribui significados especiais a cada um dos momentos que compõem sua trajetória:

Assim é que digo: eu, que o senhor já viu que tenho retentiva que não falta, recordo tudo da minha meninice. Boa, foi. Me lembro dela com agrado; mas sem saudade. Porque logo sufusa uma aragem dos acasos. Para trás, não há paz. O senhor sabe: a coisa mais alonjada de minha primeira meninice, que eu acho na memória, foi o ódio, que eu tive de um homem chamado Gramacêdo... (GSV, p. 42). 
Os pedaços de um passado que se misturam ao longo do texto são, simultaneamente, o presente de uma fala ciente dos desdobramentos que lhes tingem um sentido. O ódio, sentimento comum, pode igualmente ser visto como a "coisa mais alonjada" na vida do jagunço Riobaldo, profissional da violência que também foi. Mas o ódio certamente não foi a grande motivação que levaria Riobaldo à vida de jagunço, sendo outros os sentimentos que parecem mais incentivadores. Dos dois acontecimentos que, talvez, mais decisivos foram na mocidade de Riobaldo, um é o encontro dele, na Fazenda São Gregório, propriedade de seu padrinho e pai Selorico Mendes, com os jagunços que por lá passam e pedem curta estadia, entre eles o Alaripe, Hermógenes, Ricardão e Joca Ramiro, seus futuros companheiros, amigos e inimigos do banditismo. Isso acontece logo depois da morte da mãe de Riobaldo, quando afirma que sua vida "mudou para uma segunda parte. Amanheci mais" (GSV, p. 106). A narrativa adquire, no momento desse encontro, o tom de admiração que envolve o jovem Riobaldo, que tudo observa e se deixa impressionar, fortemente, pela canção que escuta na voz de um Siruiz. "Meu coração restava cheio de coisas movimentadas", comenta Riobaldo acerca do episódio ( $G S V$, p.115). Inquieto, é o Riobaldo que experimentara a sensação dessa proximidade ao bando de Joca Ramiro, "grande homem príncipe", que decide fugir da fazenda de Selorico Mendes, movimentar-se, e voltar para o Curralinho, onde, com o auxílio de Mestre Lucas, consegue um trabalho, que é o de professor, na Nhanva, de Zé Bebelo, personagem que o inicia no banditismo paradoxalmente (tornando-o assim simultaneamente aluno e professor), pois o discurso de Zé Bebelo afirma, politicamente, o desejo de acabar com a bandidagem ${ }^{58}$.

O outro acontecimento da mocidade de Riobaldo que o marcaria decisivamente, anterior ao contato com o bando de jagunços, é o encontro dele com o menino que é Reinaldo e que é Diadorim, como mais tarde ele viria a saber. "Amanheci minha aurora" (GSV, p. 103). Afastado no tempo, o encontro se dá quando Riobaldo, com 14 anos, encontra-se no porto do de-Janeiro, pedindo esmola para pagar uma promessa de sua mãe. O menino que é Diadorim causa grande impressão ao menino que é Riobaldo.

\footnotetext{
${ }^{58}$ Paradoxos assim podem ser explicados com certa facilidade caso se pense na realidade que ainda hoje se faz notar em algumas regiões brasileiras. Antonio Candido já observara que a iniciativa privada desempenha funções que caberiam ao poder público nos lugares em que a pressão da lei não se faz sentir. Cf. CANDIDO, Antonio. Jagunços Mineiros de Cláudio a Guimarães Rosa. In: Vários Escritos. $2^{\mathrm{a}}$ ed. São Paulo: Livraria Duas Cidades, 1977, p. 135.
} 
"Finas feições", "suave de ser, mas asseado e forte", Diadorim menino seduz Riobaldo menino, que em sua mãe não mais pensava, aceitando o passeio em canoa em que, juntos, deixam o de-Janeiro e atravessam as águas bravas do São Francisco. Travessia que se evidencia simbolicamente rica, objeto certo da crítica do Grande Sertão: Veredas, traduzse como o momento em que surge como questões para Riobaldo temas fundamentais: o amor, o medo e a coragem ${ }^{59}$.

A educação dos sentimentos de Riobaldo está em grande parte creditada à personagem Diadorim. Deve-se a Diadorim, no seu misto de homem e mulher, não apenas o modo confuso pelo qual Riobaldo aprende a amar, mas também o modo pelo qual Riobaldo desenvolve sua sensibilidade e enfrenta seus medos. "Diadorim me pôs o rastro dele para sempre em todas essas quisquilhas da natureza" ( $G S V$, p. 29). Diadorim, o Reinaldo, educa o olhar de Riobaldo:

Até aquela ocasião, eu nunca tinha ouvido dizer de se parar apreciando, por prazer de enfeite, a vida mera deles pássaros, em seu começar e descomeçar dos vôos e pousação. Aquilo era para se pegar a espingarda e caçar. Mas o Reinaldo gostava: - "É formoso próprio..." - ele me ensinou (GSV, p. 137).

Curiosa, a condição necessária à educação dos sentimentos de Riobaldo é a sua tolice, ou melhor, apenas enquanto amigo de Reinaldo, seu igual, jagunço e homem, é que ele pode questionar seus limites e ampliá-los. Assim também com o medo, sentimento constante em Riobaldo, que luta para superá-lo. "Cada hora, de cada dia, a gente aprende uma qualidade nova de mêdo!” (GSV, p. 84). É Diadorim que ainda menino o comove com o seu jeito de não ter medo. "Quieto, composto, confronte, o menino me via. - 'Carece de ter coragem...' - êle me disse” (GSV, p. 102). A frase,

\footnotetext{
${ }^{59}$ Mais do que isso, esse encontro é também, para José Carlos Garbuglio, a cisão que faz existir o Riobaldo que conhecemos pois até "ao encontro, Riobaldo leva uma vida apagada, resultante sobretudo da impossibilidade natural de ver, de sentir e de conhecer o mundo de que participa. Se existência, etimologicamente, significa secessão $(e x+$ sistere $=$ separar, por fora de), Riobaldo ainda não existe, pois está no mundo ainda como parte componente da estrutura, em estado de fusão com o cosmos. Por isso não pode contemplá-lo nem refletir sobre ele. Sua posição reflete o estágio do homem primitivo que ainda não se separou do cosmos. Estágio que vai superar a partir do conhecimento de Diadorim, seu guia e iniciador, pois é graças a ele que começa a descortinar as complexas vertentes da vida. O mundo de Riobaldo fica, então, repartido entre um passado obscuro de que muito pouco se sabe, com parcas e fragmentadas informações e o que se abre agora, dimensionado pela narrativa empreendida". Cf. GARBUGLIO, José Carlos. Rosa em Dois Tempos. São Paulo: Nankin, 2005, pp. 39-40.
} 
repetida, ecoa anos depois e mais de uma vez num Riobaldo já chefe de jagunços, UrutúBranco, que não se esqueceria dela, pois sempre oscilante, entre o medo e a coragem que deveria ter para vingar a morte de Joca Ramiro. No presente da fala de Riobaldo seu medo maior é um, "o Cujo", mas em seu passado, jornadeando, predomina um outro: "mêdo de homem humano" (GSV, 383). Na tentativa de superar esse medo que o acompanhava é que Riobaldo se compromete, na "concruz dos caminhos", com "o Pai da Mentira".

Diadorim, que dos amores de Riobaldo é o maior, "amor de ouro", confunde-se entre as confusões de Riobaldo, misturada que está aos mistérios que escapam ao seu entendimento. Enquanto vive, Diadorim é homem, duplo que divide Riobaldo. O coração fraturado de Riobaldo procura o seu conforto em Otacília, "amor de prata", e na Nhorinhá, a "prostitutriz”. "Coração mistura amores. Tudo cabe” (GSV, p. 179).

Riobaldo conhece, com essas três mulheres, três formas de amar. Nhorinhá e Otacília são lembranças de um Riobaldo que está ao lado de Diadorim, causa de suas dúvidas, e por isso mesmo é que se apresentam como possíveis soluções ao estado angustiante em que ele se encontra. "Todo amor não é uma espécie de comparação?" $(G S V, \text { p. 150) })^{60}$.

De qualquer modo, é o "amor de ouro" de Riobaldo que mais influi em sua trajetória, despertando-lhe sentimentos inéditos desde o encontro inicial, trazendo-o de volta à companhia dos jagunços quando do segundo encontro entre eles (Riobaldo havia naquele momento, em uma de suas crises, escapado ao bando de Zé-Bebelo, e foi o encontro com Reinaldo que lhe motivou o retorno ao banditismo), conduzindo-o pelo sertão no enfrentamento de batalhas e incentivando-o às ações que lhe determinam o caráter.

\footnotetext{
${ }^{60}$ Sobre os amores de Riobaldo há o excelente texto de Benedito Nunes, que analisa as "diferentes formas ou estágios de um mesmo impulso erótico" no narrador: "primitivo e caótico em Diadorim, sensual em Nhorinhá e espiritual em Otacília". Cf. NUNES, Benedito. O Amor na Obra de Guimarães Rosa. In: Guimarães Rosa. Eduardo F. Coutinho (org.). 2a ed. Rio de Janeiro: Civilização Brasileira, 1991, pp. 144169. (Coleção Fortuna Crítica).
} 
II.

Mal que em minha vida aprontei, foi numa certa meninice em sonho - tudo corre e chega tão ligeiro -; será que se há lume de responsabilidades?

Se sonha; já se fez... (GSV, p. 26).

Quando Riobaldo lembra dos acontecimentos de sua juventude, desconhece como algumas coisas ocorreram. “Ah, a mocidade da gente reverte em pé o impossível de qualquer coisa!” (GSV, p. 151). Crente, como afirma ser, nos desígnios do destino, Riobaldo não rejeita que em sua trajetória o controle e o entendimento daquilo que ocorria muita vez lhe escapava. "A gente vive não é caminhando de costas?” (GSV, p. 526). Sendo assim, necessário é reconhecer os momentos em que Riobaldo supera seus receios e se impõe ao operar decisões. Desses, dois são os momentos que se destacam: o primeiro é quando ele toma a palavra para opinar no julgamento de Zé-Bebelo, e o segundo é quando ele resolve "fechar o trato, fazer o pacto" nas Veredas-Mortas com "o Tristonho".

Antes, já havia Riobaldo tomado decisões mais ou menos refletidas. Por exemplo, quando foge, ainda moço, da fazenda de Selorico Mendes e volta para o Curralinho, realiza Riobaldo, autônomo, uma decisão. Ou então, quando Riobaldo escapa ao bando de Zé-Bebelo, no início de sua trajetória como jagunço, faz isso também como decisão necessária às suas vontades de "resolver os projetos em seu espírito". Mas deve ser reconhecido que essas duas decisões são fugas, desvios, distintas das posteriores que se apresentam como enfrentamentos.

No momento em que o bando de Joca Ramiro faz do inimigo Zé-Bebelo prisioneiro, realiza-se o julgamento em que os jagunços reunidos decidem o destino dele. Durante o julgamento diversas posições se apresentam e contrastam. O Hermógenes, como era de esperar, quer a morte de Zé-Bebelo, e assim também Ricardão, seu companheiro. Sô Candelário, inflamado, pensa que um duelo de facas resolveria bem a questão, mas não tem Zé-Bebelo por criminoso, como Titão Passos e João Goanhá, que não acham justo a morte como sentença para uma pessoa que ali no sertão guerreia como todos eles. Estabelecido o impasse, ainda se apresentam duas figuras menores, até que, "feito menino em escola", Riobaldo inicia a sua fala, superando seus receios. 
A argumentação de Riobaldo, que fala alto sua "verdade forte", defende ZéBebelo. Riobaldo sustenta sua postura ao discursar em favor do passado digno e da integridade de Zé-Bebelo. Em seguida, questiona os efeitos que trariam a morte de ZéBebelo para eles jagunços; pergunta-se, dar cabo de Zé-Bebelo honraria ou envergonharia o bando de Joca Ramiro? E prossegue, sugerindo Riobaldo que bom seria se Zé-Bebelo fosse embora da região deles, deixando as terras de Minas Gerais e Bahia. "Sei que me desconheci" (GSV, p. 259), afirma Riobaldo, reconhecendo o passo que dera. Riobaldo vacila, mas consegue ali impor seus valores, e suas palavras obtêm vitorioso resultado, pois Joca Ramiro, por fim, acata a sugestão de Riobaldo no acordo que faz com ZéBebelo.

O Riobaldo que se destaca entre os jagunços neste momento oscila entre a satisfação e o arrependimento. "Eu quis, de repentemente, tornar a ficar nenhum, ninguém, safado humildezinho...” (GSV, p. 262). Mas a aprovação de Diadorim não tarda, conferindo ao amigo a qualidade de "homem de tôdas valentias". É preciso notar que Diadorim reconhece a coragem de Riobaldo, dando menor valor às palavras de seu discurso, mas apreciando com louvores o "rompante brabo", "acendido", que nele "exportava uma espécie de autoridade". Anuncia-se, assim, durante o julgamento de ZéBebelo, o Riobaldo que seria o Urutú-Branco, que, com seu bando, vingaria a morte de Joca Ramiro.

Certamente, as palavras de Riobaldo contribuem decisivamente na sentença mais amena que recebe Zé-Bebelo. Hermógenes, contrariado durante o julgamento, é o autor do próximo acontecimento significativo: o assassinato de Joca Ramiro. Assim, a responsabilidade de Riobaldo está claramente vinculada à necessidade de vingança que exige a morte de Joca Ramiro, sem que se esqueça a sua fidelidade ao amigo Diadorim, filho do "grande homem príncipe", que já bastaria como motivação.

O balanço que Riobaldo faz de sua trajetória, quando pensa no presente de sua fala, deve ser observado:

Eu era assim. Sou? Não creia o senhor. Fui o chefe Urutú-Branco - depois de ser Tatarana e de ter sido o jagunço Riobaldo. Essas coisas larguei, largaram de mim, na remotidão. Hoje eu quero é a fé, mais a bondade. Só que não entendo quem se praz com 
nada ou pouco; eu, não me serve cheirar a poeira do cogulo - mais quero mexer com minhas mãos e ir ver recrescer a massa... (GSV, p. 512).

A transformação dos nomes revela a transformação do próprio narrador. Se no presente Riobaldo "quer a fé, mais a bondade", faz isso com seus motivos, pois no passado ele não se satisfez com "nada ou pouco", quis mais, e foi assim que parece haver se consagrado como o chefe Urutú-Branco. A segunda decisão significativa que toma Riobaldo, que é o pacto com “o Tranjão”, por ele procurado nas Veredas-Mortas, influi em toda sua narrativa. Ao lado do amor do narrador por Diadorim, as dúvidas que acometem Riobaldo sobre a existência do diabo e, conseqüentemente, sobre a validade do trato ao qual ele se submeteu colocam-se como tema fundamental do Grande Sertão: Veredas. É após o suposto pacto que Riobaldo se transforma no chefe Urutú-Branco, antes:

Noção eu nem acertava, de reger; eu não tinha o tato mestre, nem a confiança dos outros, nem o cabedal de um poder - os poderes normais para mover nos homens a minha vontade (GSV, p. 347).

Ou então:

Um com o meu retraimento, de nascença, deserdado de qualquer lábia ou possança nos outros - eu era o contrário de um mandador (GSV, p. 354).

Riobaldo "era o contrário de um mandador", mas após o pacto apresenta-se de modo inverso. A transformação é nítida, Riobaldo passa a dar ordens, responder a seus companheiros, mais falar, tornando-se, por fim, chefe do bando. O texto do Grande Sertão: Veredas, como fala de um narrador já velho, apresenta-se com a perspectiva do Riobaldo pactário, consciente das mudanças que ele sofreu com o suposto trato. "Eu ainda não era ainda. Se ia, se ia", reconhece Riobaldo ao falar de sua fase anterior ao pacto $(G S V$, p. 369). A condição do narrador anterior ao pacto é por ele mesmo vista como um estado de insuficiência. Ansioso, jagunço que não se satisfazia com "nada ou pouco", que sempre desgostou "de criaturas que com pouco e fácil se contentam” (GSV, 
p. 142), e confuso em relação às coisas que não entendia, como seu amor por Diadorim, Riobaldo se dispõe ao trato ambiciosamente. "Eu queria ser mais do que eu" (GSV, p. 397). Numa tentativa de superar suas fraquezas, Riobaldo se compromete definitivamente, comprometendo assim a narrativa de sua vida que demonstra a todo momento sua preocupação no presente com a existência do "Um-que-não-existe". Riobaldo, após o pacto, "ficou sendo":

E, o que era que eu queria? Ah, acho que não queria mesmo nada, de tanto que eu queria só tudo. Uma coisa, a coisa, esta coisa: eu somente queria era - ficar sendo! (GSV, p. 396).

Já na condição de chefe, há um momento exemplar deste outro Riobaldo: do alto de uma pedra, ele olha para os seus homens, e segundo ele, eles "nem careciam de ter nomes", valiam o querer dele, "para viver e para morrer". "Tinham me dado em mão o brinquedo do mundo" (GSV, p. 414).

Por certo, os resultados vitoriosos do chefe Urutú-Branco acompanham significativas frustrações. O pacto, que pode ser lido como responsável pelo modo forte e corajoso com o qual age o comandante Riobaldo, impõe-lhe, por isso mesmo, uma inquietação que, para sua crendice, é questão insolúvel e incomoda o presente de sua fala. A morte de Hermógenes, o traidor assassino de Joca Ramiro, que põe termo às batalhas de Riobaldo, custa a vida de Diadorim, seu "amor de ouro". "Eu estou depois das tempestades" (GSV, p. 560).

A trajetória de Riobaldo inclui ações bem-sucedidas, inclui aprendizados, a descoberta de amores, sucessivos acidentes relevantes, guerras, momentos pacíficos, perdas irreparáveis, tristezas, alegrias etc., acontecimentos e sentimentos narrados, no presente da enunciação, com as palavras de quem desconfia de que, ao final de tudo isso, possa ainda resultar alguma espécie certa de "progresso" para si. "Esta vida é de cabeçapara-baixo, ninguém pode medir suas perdas e colheitas" (GSV, p. 138) ${ }^{61}$. A insegurança

\footnotetext{
${ }^{61}$ Como bem observou Susana Kampff Lages, um "texto como Grande Sertão: Veredas, em que as aventuras de um jagunço são apresentadas como rememoração-confissão daquele que as viveu, pode ser facilmente reconduzido a um enquadramento evolucionista: o próprio protagonista narra a história de sua
} 
de Riobaldo, que constantemente assume suas incertezas, duvida das atitudes que tomou, problematiza o seu desenvolvimento como protagonista do romance de Guimarães Rosa. "Eu nunca tinha certeza de coisa nenhuma" (GSV, p. 354). Riobaldo faz entender que no passado muito ele não soube, e no presente muito ele não entende, sensível às mudanças que sofreu e à contínua movimentação das pessoas e da vida. "De cada vivimento que eu real tive, de alegria forte ou pesar, cada vez daquela hoje vejo que eu era como se fôsse diferente pessoa. Sucedido desgovernado" (GSV, p. 95). Isso posto, liga-se ao percurso de Riobaldo e à sua experiência o sentimento de incerteza que abala as bases de um desenvolvimento seguro, embaralhando os significados que, lidos na trajetória do protagonista, não asseguram contudo um sentido único aos movimentos dele, mas acentuam o trânsito de suas vivências.

Próximo à conclusão de nosso trabalho, retomaremos uma vez mais o problema da trajetória de Riobaldo. Por ora, basta ressaltar que em Riobaldo sua "competência foi comprada a todos os custos, caminhou com os pés da idade" (GSV, p. 46).

vida como processo de 'individuação', de uma evolução positiva da inciência à sabedoria, da carência à plenitude. A leitura que vê um progresso espiritual no personagem tem como pressuposto a crença no triunfo do Bem como conseqüência necessária a toda ação humana". Evitamos tal postura em nossa análise. Cf. LAGES, Susana Kampff. João Guimarães Rosa e a Saudade. São Paulo: Ateliê Editorial; Fapesp, 2002, p. 28. 


\section{Andeja vida: Franz Biberkopf}

I.

$$
\begin{aligned}
& \text { Porque a rua hoje é um fato conflitante, é um elemento } \\
& \text { de desgosto, o cara sai de casa, pisou na rua, pumba! } \\
& \text { Conflito. Conflito, você está na área de conflito, se cuide, } \\
& \text { salve-se quem puder! (João Antônio, Merdunchos) }{ }^{*} \text {. }
\end{aligned}
$$

A trajetória de Franz Biberkopf que narra o Berlin Alexanderplatz está dividida nos nove livros que compõem o romance, cada um deles, por sua vez, dividido em capítulos. O livro de Döblin se coloca de modo bastante direto, toda a trajetória de Franz Biberkopf já é apresentada na abertura do livro de modo resumido e sem nenhum volteio, restando apenas à curiosidade do leitor entrar em contato com os fatos em si e seus detalhes. Sabe-se, imediatamente, que Franz Biberkopf será atingido três vezes, até que alcance sua "iluminação"; que um verdadeiro "tratamento de choque" caracterizará sua trajetória desde o momento inicial do romance que o apresenta recém-saído de um presídio e com o forte desejo de ser um "homem decente".

Sobre o passado de Franz Biberkopf pouco se comenta, apenas que foi operário da construção civil e do transporte de mobílias e que estivera preso por matar sua antiga companheira de nome Ida. Cumpridos os seus quatro anos de reclusão, o protagonista deixa o cárcere e enfrenta Berlim, de modo bastante inseguro, sofrendo do claro contraste que a agitação urbana estabelece com a rotina segura de seu passado de prisioneiro. Durante quase todo o livro, sobretudo nos momentos mais problemáticos que enfrenta, Franz Biberkopf lembrará do conforto desse seu passado, quando não estava exposto às adversidades da agitação sofrida que marcam a vida de uma pessoa pouco privilegiada como ele.

De início, transtornado, os movimentos de Franz Biberkopf são precários, e ele perambula sem destino pelas ruas de Berlim. Neste momento, será um judeu desconhecido que o levará para sua casa e tentará ajudá-lo ao conversar com ele, que mal se comunica. Na casa do judeu, Franz Biberkopf atinge ainda um estado lamentável de desespero em sua desorientação; será preciso que o judeu que o carregou the conte uma

\footnotetext{
* ANTÔNIO, João. Merdunchos. In: Os Melhores Contos. Seleção de Antônio Hohfeldt. $2^{\mathrm{a}}$ ed. São Paulo: Global, 1997, p. 97.
} 
história em cujo desfecho, que vem com o auxilio de um outro judeu que ali chega, desenha-se uma situação que a Franz Biberkopf parece interessar para que o seu frágil equilíbrio seja recobrado. A história narrava a curta vida de um certo Stefan Zannowich, um impostor que a todos enganava e vivia com isso uma vida de príncipe até que, desmascarado, é preso e põe fim à sua vida, terminando o seu corpo junto ao lixo da cidade. Franz Biberkopf sente-se neste momento tocado, indigna-se e conclui:

[...] então nós não somos nada porque uma vez fizemos algo de errado? Todo mundo pode se levantar de novo, recuperar-se depois de ter estado trancafiado, não importa o que fizeram! (Arrepender-se! A gente precisa de alívio! Atacar! Aí tudo fica para trás, tudo acabou, medo e tudo. $)(B A, t b, \text { p. } 24)^{62}$.

Resoluto, Franz Biberkopf sai às ruas, procura mulheres, paga prostitutas, e ainda visita a irmã de sua falecida companheira Ida. "O Franz, o Franz! Franz voltou à vida, Franz voltou!” (BA, tb, p. 34) $)^{63}$. Com o sentimento de quem torna a viver e quer as coisas mudadas, Franz Biberkopf, ao final do primeiro livro, assume confiante a fixa idéia de ser "um homem decente". "Ele jurou a todo mundo e a si mesmo manter-se um homem decente" $(B A, t b, \text { p. } 39)^{64}$.

A primeira coisa que fascina o protagonista do livro parecem ser os discursos que lhe chegam aos ouvidos. Franz Biberkopf ergue sua cabeça pela primeira vez após escutar os judeus que o impressionam e, logo em seguida, anima-se com a fala de um representante dos comerciantes ambulantes de Berlim, que faz com que ele, impensadamente, filie-se ao grupo deles de modo imediato sem nem saber como poderá colaborar financeiramente com isso, desempregado que ainda está. Ingênuo, Franz Biberkopf acha que o importante "é ter cabeça e usá-la e saber o que acontece ao nosso redor para não ser derrubado de saída" $(B A, t b, \text { p. } 56)^{65}$. Enquanto ensaia os seus

\footnotetext{
62 “'Ja, sind wir denn nichts, weil wir mal was getan haben? Es können alle wieder auf die Beene kommen, die gesessen haben, und die können gemacht haben, wat sie wollen.' (Was bereuen! Luft mu $\beta$ man sich machen! Drauf losschlagen! Dann liegt alles hinter einem, dann ist alles vorbei, Angst und alles.)" (BA, pp. 29-30).

63 ““'Allens Franz, allens Franz! Franz ist wieder lebendig, Franz ist wieder da!'” (BA, p. 41).

64 "Er hat aller Welt und sich geschworen, anständig zu bleiben" (BA, p. 46).

65 "Die Hauptsache ist, Kopf haben, und da $\beta$ man ihn gebraucht, und da $\beta$ man wei $\beta$, was um eenen los ist, da $\beta$ man nicht gleich umgeschmissen wird" (BA, pp. 64-65).
} 
primeiros passos em sua recente condição de liberto, Franz Biberkopf procura o apoio das palavras reconfortantes. "Ser decente e isolado. Essa é minha palavra" $(B A, t b, \text { p. } 59)^{66}$. Após enfrentar uma de suas primeiras situações problemáticas, serão as palavras encontradas em um jornal que trarão de volta a Franz Biberkopf alguma alegria e a calma de que necessita. Tal situação mencionada é um pequeno conflito que a alienação política de Franz Biberkopf provoca em um bar freqüentado pelos "vermelhos". Repreendido por carregar uma braçadeira com a suástica hitlerista, o vendedor de jornais Franz Biberkopf entra numa discussão que o deixa fora de si, mas ainda consegue nosso protagonista nesse momento se controlar, sem que haja no bar maior confusão. "É preciso ficar feliz por ter pernas boas e não estar na prisão", afirma Biberkopf para o seu próprio bem ( $B A$, $t b$, p. 83$)^{67}$. A calma almejada, como já notamos, é devolvida a este vendedor ambulante quando ele encontra as palavras da manchete de um de seus jornais. "Do infortúnio à felicidade", lê-se na manchete $(B A, t b, \text { p. } 89)^{68}$, lendo-se ali também o desejo de Biberkopf de que assim seja a transformação que possa operar a sua trajetória.

$\mathrm{O}$ segundo livro de certa forma não coloca Franz Biberkopf em maiores problemas, mas, como nos alerta o narrador do livro, isto é apenas uma trégua. "Eu não o convoquei para um jogo, mas para viver sua dura, verdadeira e esclarecedora existência" $(B A, t b, \text { p. } 41)^{69}$. Assim sendo, já no terceiro livro, Biberkopf sofre o primeiro dos três golpes anteriormente anunciados. Franz Biberkopf, agora vendedor de mercadorias diversas, envolve-se com uma viúva que lhe dá o prazer de sua companhia por algumas horas e algum dinheiro, confiando assim sua mercadoria a ela, mas, quando volta para recuperá-la, Otto Lüders, seu companheiro de trabalho e tio de sua namorada Lina, havia lá passado, levando a sua mercadoria. Com isso, Biberkopf, traído, perde a mercadoria e o contato com a viúva, isolando-se de seus próximos, inclusive de Lina. Posteriormente, num bar, "Franz reflete sobre o que teria havido, sua cabeça lhe pesa, tomba para a frente

\footnotetext{
66 ““Anständig bleiben und for sich bleiben. Das ist mein Wort”” (BA, p. 67).

67 “"Man mu $\beta$ froh sein, wenn man seine Beine hat und draußen ist"” $(B A$, p. 95).

68 “"Durch Unglück zum Glück”" (BA, p. 102).

69 "Ich habe ihn hergerufen zu keinem Spiel, sondern zum Erleben seines schweren, wahren und aufhellenden Daseins" (BA, p. 47).
} 
como se estivesse dormindo, o dono do bar pensa que está cansado, mas é na amplidão e no vazio que suas pernas escorregam" $(B A, t b, \text { p. 106 })^{70}$.

Incapaz de reagir, é o seu passado de prisioneiro que mais uma vez lhe vem à lembrança, opondo à reclusão, paradoxalmente, sua condição de liberto como um castigo:

[...] esse é meu castigo, eles me soltaram, os outros ainda estão descascando batatas na prisão junto ao grande monte de lixo, e eu tenho de pegar o bonde, maldição, não era tão mal assim por lá $(B A, t b, \text { p. 106 })^{71}$.

Durante o quarto livro, Franz Biberkopf "nota que seu princípio deve ter uma falha" $(B A, t b, \text { p. } 113)^{72}$, mas esse reconhecimento ainda pouco modifica a sua vida. $\mathrm{O}$ que lemos no quarto livro é uma intensa crise de Franz Biberkopf, que demora para reagir, bebe e dorme por duas semanas, e sofre de dores estomacais e alucinações, encontrando-se péssimo fisicamente quando resolve tomar alguma atitude, sofrendo da abstinência de álcool. Franz Biberkopf procura Minna, a irmã de Ida, sua ex-mulher por ele assassinada, mas encontra apenas Karl, o marido dela, que o trata mal, deixando-o furioso, mas ele mais uma vez se controla para não agir com violência, carregando então o sentimento de bravura, afirmando "não ter medo de nada" ao final do quarto livro. "Eu tenho punhos. Veja só que músculos os meus" $\left(B A, t b\right.$, p. 151) ${ }^{73}$.

Não tarda para que surja no romance o segundo golpe que leva o novamente vendedor de jornais Franz Biberkopf. O quinto livro inicia com a afirmação de que o "nosso homem retorna ao ponto onde estava, não aprendeu nada, nem discerniu nada" $(B A, t b, \text { p. } 153)^{74}$. Teimoso em sua ingenuidade, Biberkopf resiste em acrescentar algo ao seu entendimento, repete seus erros, chegando mesmo a incomodar o leitor que dele espera reações melhor pensadas. É neste quinto livro que surge a figura de Reinhold, personagem cuja amizade dedicada do insistente Franz Biberkopf somente lhe rende

\footnotetext{
70 "Franz überlegt, wie das passiert sei, dabei wird ihm der Kopf schwer, fällt ihm wie im Schlaf nach vorn über, der Wirt glaubt, er ist müde, aber es ist die Blässe, Weite und Leere, darin rutschen auch seine Beine ab" (BA, p. 120).

71 "Das ist die Strafe, mich haben sie rausgelassen, die andern buddeln noch Kartoffeln hinter dem Gefängnis an dem großen Müllberg, und ich mu $\beta$ die Elektrische fahren, verflucht, es war doch ganz schön da" (BA, p. 120).

72 "Er merkt, sein Grundsatz, so einfach er ist, mu $\beta$ irgendwo fehlerhaft sein" (BA, p. 129).

73 “"Ich habe Fäuste. Sieh mal, was ich für Muskeln habe”" (BA, p. 175).

74 “[...] der Mann steht wieder da, wo er stand, er hat nichts zugelernt und nichts erkannt” (BA, p. 177).
} 
prejuízos. De início, a relação de Biberkopf com Reinhold, figura sombria, é alimentada por uma troca de mulheres que entusiasma o ex-penitenciário. Reinhold é um personagem que não se contenta com a companhia de uma mulher que ultrapasse a permanência de algumas poucas semanas ao seu lado, necessitando assim, de tempo a tempo, substituir suas companheiras. Para Reinhold, a amizade de Franz Biberkopf tem seu proveito, já que nosso protagonista, num primeiro momento, aprecia a idéia de tomar para si as mulheres por Reinhold descartadas. Mas, quando Franz Biberkopf, já com a segunda mulher que de Reinhold resta em suas mãos, resolve que tal troca de amantes não deve prosseguir, acreditando que com a sua decisão faz bem a Reinhold, cria-se a discórdia que não lhe custará pouco. "Franz Biberkopf metera-se em má companhia" $\left(B A, t b\right.$, p. 167) ${ }^{75}$.

Os acontecimentos seguintes do romance envolvem ambos, Biberkopf e Reinhold, numa noturna ação criminosa. Com o bando de Pums, que é um trambiqueiro, um falso negociante de frutas, ajudam os dois "amigos" no roubo de uma mercadoria qualquer. Porém, ao contrário de Reinhold, Biberkopf não estava ciente de que esse Pums liderava uma quadrilha de arrombadores e ladrões, e de que ele, Franz Biberkopf, arriscava-se ao aceitar aquele trabalho que se the oferecia ocasionalmente. Biberkopf, é certo, desconfiava da integridade de Pums e de seus homens, hesitando ao ser convidado para um trabalho com eles, mas, ingênuo e confiante que era em seu companheiro Reinhold, aceita mecanicamente o convite de Pums ao notar que também o seu "amigo" os acompanharia. Quando Biberkopf percebe que estão a roubar uma mercadoria, arrependese, causando um certo desconforto entre os outros criminosos. "Quero sair daqui, sair daqui, patifes, cachorros, não quero isso" $(B A, t b, \text { p. 199 })^{76}$. Terminado o roubo, voltam os ladrões para o carro que dispara em fuga e é perseguido por um outro automóvel. Reinhold, que já estava descontente com Franz Biberkopf, aproveita a situação, atirandoo para fora do carro em movimento, facilitando para que o automóvel que os perseguia passasse por cima de Biberkopf, atingindo-o violentamente.

Franz Biberkopf, um homem forte, sobrevive, mas o incidente, que é o segundo dos três grandes golpes que sofre o protagonista, custa-lhe o seu braço direito.

\footnotetext{
75 “'In eine dunkle Gesellschaft war Franz Biberkopf geraten [...]” (BA, p. 193).

76 "Ich möchte weg, ich möchte weg, die Gauner, die Hunde, ich will das gar nicht" (BA, p. 229).
} 
II.

Tenho algo a fazer, vai acontecer alguma coisa, não vou fugir, sou Franz Biberkopf (BA, tb, p. 211).

O maneta Franz Biberkopf não é um sujeito vingativo, como se lê no sexto livro do romance, o mais longo de toda a narrativa. Conquanto ele não apresente uma verdadeira transformação de nosso protagonista, como se verá, o sexto livro do Berlin Alexanderplatz aciona uma nova fase do mesmo Franz Biberkopf. "Agora vocês não verão Franz Biberkopf bebendo e escondendo-se. Agora o vêem sorrir: é preciso dançar conforme a música" $\left(B A, t b\right.$, p. 203) ${ }^{77}$.

Inicialmente, são os antigos amigos de Franz Biberkopf, Herbert e Eva, que o ajudam na sua recuperação e pagam as suas despesas. Desejosos de alguma justiça, esses amigos de Biberkopf the cobram um esclarecimento que os faça compreender de que modo ele pôde perder o braço. Mas Biberkopf não se interessa por um acerto de contas, desvia de seu passado e busca por uma nova postura que, enfim, revele seu valor. "Franz Biberkopf olha reto à frente e pensa: não tenho nada a ver com o que estão dizendo. E, se fizerem alguma coisa, também não tenho nada a ver com isso. Não vai fazer meu braço crescer, e está certo o braço ter sumido. Ele tinha de sumir, não há como reclamar. E não é o fim ainda" $(B A, t b, \text { p. } 218)^{78}$.

Franz Biberkopf volta às ruas, faz novas amizades, novos trambiques, esconde seu envolvimento com o bando de Pums, e carrega a convicção de que o necessário neste momento é ganhar o seu dinheiro, pois a "vida afinal the valeu de alguma coisa" ( $B A, t b$, p. 223) ${ }^{79}$. "Sou homem livre, ou ninguém”, afirma o "mais lúcido" Biberkopf de que se agora tem notícia $(B A, t b, \text { p. } 227)^{80}$.

De acordo com este momento da vida de Franz Biberkopf, surge-lhe, apresentado por sua amiga Eva, o seu grande amor neste romance: Mieze, uma mocinha "de primeira" que "encanta Franz ao primeiro olhar" $(B A, t b$, p. 242). Mieze não se torna apenas a

\footnotetext{
77 "Jetzt seht ihr Franz Biberkopf nicht saufen und sich verstecken. Jetzt seht ihr ihn lachen: man muß sich nach der Decke strecken" (BA, p. 235).

78 "Franz Biberkopf blickt geradeaus, denkt: das geht mich nichts an, was die sagen. Und wenn die was machen, das geht mich auch nichts an. Davon wächst mir der Arm nicht, und das ist auch ganz richtig, da $\beta$ der Arm weg ist. Der mußte ab, da gibts nichts gegen zu bellen. Und das ist noch nicht das letzte" (BA, p. 252).

79 "Das Leben hat ihm doch etwas genützt" (BA, p. 259).

80 "Ich bin ein freier Mann oder keiner" (BA, p. 264).
} 
responsável pelos sentimentos mais nobres de nosso protagonista, mas também coloca em cena o rufião Biberkopf, estabilizando-o em vários sentidos:

Em que alturas está agora o nosso Franz Biberkopf? Sua vida está boa, como tudo mudou! Esteve perto da morte, e como se ergueu! Que criatura saciada ele é agora, a quem nada falta, comida, bebida ou roupa. Tem uma namorada que o faz feliz; tem mais dinheiro do que gasta; já pagou toda sua dívida com o Herbert; Herbert, Emil, Eva são seus amigos, querem o seu bem. Deixa-se ficar dias a fio com Herbert e Eva, espera por Mieze, vai até o lago Müggelsee, onde rema com dois outros sujeitos: pois Franz fica cada dia mais habilidoso, mais forte no braço esquerdo. De vez em quando ele aparece na Münzstrasse, também, ou na casa de penhores $(B A, t b, \text { p. } 250)^{81}$.

Com o nosso protagonista em boas condições, é com alguma surpresa, ou decepção, que talvez o leitor mais esperançoso reaja aos acontecimentos do final do sexto livro, quando Franz Biberkopf procura por Reinhold e acredita novamente em sua amizade. Feliz, Biberkopf ainda encerra o sexto livro a dançar no bar de Herbert, e "as pessoas a quem mais ama enquanto dança com Eva são duas: uma é a sua Mieze, que gostaria que estivesse presente, a outra é... Reinhold" $(B A, t b, \text { p. } 282)^{82}$. Assim, o velho Biberkopf, que por um momento pareceu "mais lúcido", dá início à repetição dos mesmos erros anteriores, demonstrando que o seu misto de ingenuidade e tolice lhe dificulta qualquer aprendizado. O comportamento insensato do Franz Biberkopf que se reaproxima de Reinhold não encontra qualquer explicação razoável, tendo em vista que nem mesmo é um oculto desejo de vingança que o move, mas um inexplicável sentimento de admiração que ele parece nutrir pelo personagem.

Simploriamente, Biberkopf acredita que aprendeu "uma lição" ao perder o braço, compreendendo o ato de Reinhold como justa reação à sua condição atrapalhada e

81 “Auf welcher Höhe steht jetzt unser Franz Biberkopf! Wie gut geht es ihm, wie hat sich alles gewandelt! Er war schon dicht am Tode, wie hat er sich erhoben! Welch sattes Geschöpf ist er jetzt, dem nichts fehlt, nichts am Essen, Trinken, nichts an der Kleidung. Ein Mädel hat er, das ihn glücklich macht, Geld hat er, mehr als er verbraucht, seine ganz Schuld an Herbert hat er schon abgetragen, Herbert, Emil, Eva sind seine Freunde, sie meinen es gut mit ihm. Tagelang sitzt er bei Herbert und Eva herum, erwartet Mieze, fährt zum Müggelsee raus, wo er mit zwei andern zusammen rudert: denn Franz wird von Tag zu Tag geschickter und stärker im linken Arm. Ab und zu horcht er an der Münzstraße, an der Pfandkammer herum" (BA, p. 290).

82 "Und am innigsten liebt er, während er mit Eva tanzt, liebt er zwei: die eine ist seine Mieze, die er gern da hätte, der andere ist - Reinhold" ( $B A$, p. 328). 
nervosa que o tornava uma pessoa suspeita e indesejada durante a ação ilegal do bando de Pums daquela noite. Assim, livre de pensamentos que supostamente poderiam o incomodar, Franz Biberkopf aproxima-se mais uma vez do bando de Pums, ignorando os conselhos de Herbert, Eva e Mieze, e obtém com isso alguma vantagem financeira. Porém, as vantagens do seu tolismo são poucas e logo cessam, e o esperado terceiro golpe logo atinge Biberkopf, resultado de sua proximidade com Reinhold, que o convence a lhe apresentar a sua Mieze. Após algumas manobras, que se aproveitam também da ingenuidade de Biberkopf, Reinhold consegue se aproximar de Mieze, arranjando um meio de ganhar a sua companhia em um passeio. Durante o passeio em Freienwalde, Reinhold agride Mieze, tirando-lhe a vida ao final do sétimo livro do romance.

Dotado de uma lentidão e ignorância exemplares, Franz Biberkopf desconhece que foi traído mais uma vez e demora a entender que perdeu Mieze para sempre. Quando as coisas começam a ficar mais claras para ele, Biberkopf já está ao lado de Reinhold na página de um jornal que os acusa de autores do assassinato de Mieze. A burrice levou-o à ruína, e o que se lê no oitavo livro, e também no começo do nono livro do Berlin Alexanderplatz, é a lamentável derrocada de Franz Biberkopf. "Franz pensa: minha vida acabou, estou farto, acabou-se" $(B A, t b, \text { p. } 368)^{83}$. O desespero domina os sentimentos do nosso protagonista, que enfrenta agora a maior de suas crises, a crise que finalmente lhe trará uma transformação significativa em sua vida.

Franz Biberkopf não encontra um meio de se vingar de Reinhold, suportando o seu ódio e a sua dor solitariamente, o que o transtorna profundamente. Momentos depois, quando é preso, notam os responsáveis que ele deve ser encaminhado para um manicômio, tal é o seu estado. Distante de sua sanidade, Franz Biberkopf vive o seu tormento e aproxima-se da morte, renunciando insistentemente os tratamentos que pretendem lhe recuperar a saúde. Quando a situação torna-se realmente grave e sua vida corre perigo, é a própria Morte que lhe aparece e dialoga com ele, fazendo-o enxergar duramente todos os seus erros, dizendo-lhe que o "mundo não se importa com ele", Franz Biberkopf, que geme e sofre e sente a dor que lhe causa o reconhecimento de seus consecutivos tropeços inconseqüentes. O diálogo de Franz Biberkopf com a Morte

83 “Da findet Franz: Mein Leben ist zu Ende, mit mir ist es aus, ich habe genug" (BA, p. 426). 
elimina-o, colocando em cena o seu substituto, o renascido Franz Karl Biberkopf, um auxiliar de porteiro de uma fábrica de médio porte.

Andamos por uma alameda escura, primeiro não havia lampiões acesos, a gente só sabia que o caminho era comprido, aos poucos ficou mais claro, mais claro, por fim vê-se o lampião ali, e afinal a gente lê a placa da rua debaixo dele. Foi um processo de revelação muito peculiar. Franz Biberkopf não andou por essa rua como nós. Ele correu desenfreadamente por essa rua escura, bateu nas árvores, e quanto mais corria mais batia nas árvores. Estava escuro, e ao bater nas árvores ele fechou os olhos horrorizado. E quanto mais batia, mais horrorizado fechava os olhos. Com a cabeça esburacada, quase sem sentidos, finalmente chegou. Ao cair, abriu os olhos. Então o lampião brilhava claro por cima dele, e lia-se a placa $(B A, t b, \text { p. } 424)^{84}$.

Como se lê no trecho acima, Franz Biberkopf é dono de uma trajetória bastante acidentada que, se o fez aprender algo, não o fez de uma forma pacífica, mas impingindolhe golpes nada agradáveis. A situação do Franz Karl Biberkopf é a de um homem conformado em seus limites:

Muita desgraça vem do fato de se andar sozinho. Quando há muitos, a coisa é diferente. A gente precisa acostumar-se a escutar os outros, pois o que os outros dizem também me diz respeito. Aí percebo quem eu sou e o que posso me propor. Ao meu redor e por toda parte se luta a minha luta, preciso prestar atenção, antes que note chegou minha vez $(B A, t b, \text { p. } 425)^{85}$.

Franz Karl Biberkopf é talvez um sujeito que, assim como o Riobaldo do Grande Sertão: Veredas, reconheceria que no passado muito ele não soube, mas ao contrário do

\footnotetext{
84 "Wir sind eine dunkle Alle gegangen, keine Laterne brannte zuerst, man wußte nur, hier geht es lang, allmählich wird es heller und heller, zuletzt hängt da die Lanterne, und dann liest man endlich unter ihr das Straßenschild. Es war ein Enthüllungsproze $\beta$ besonderer Art. Franz Biberkopf ging nicht die Straße wie wir. Er rannte drauflos, diese dunkle Straße, er stie $\beta$ sich an Bäume, und je mehr er ins Laufen kam, um so mehr stie $\beta$ er an Bäume. Es war schon dunkel, und wie er an Bäume stie $\beta$, pre $\beta$ te er entsetzt die Augen zu. Mit zerlöchertem Kopf, kaum noch bei Sinnen, kam er schließlich doch an. Wie er hinfiel, machte er die Augen auf. Da brannte die Laterne hell über ihm, und das Schild war zu lesen" (BA, p. 499).

85 "Viel Unglück kommt davon, wenn man allein geht. Wenn mehrere sind, ist es schon anders. Man mu $\beta$ sich gewöhnen, auf andere zu hören, denn was andere sagen, geht mich auch an. Da merke ich, wer ich bin und was ich mir vornehmen kann. Es wird überall herum um mich meine Schlacht geschlagen, ich mu $\beta$ aufpassen, ehe ich es merke, komm ich ran" (BA, p. 500).
} 
jagunço mineiro, o berlinense provavelmente preferisse esquecer a singular história que morreu com o nome Franz Biberkopf e não recordá-la como o faz o Urutú-Branco no romance de Guimarães Rosa. "Nada mais há a relatar sobre sua vida" ( $B A, t b$, p. 424$)$, confirma o narrador ao demonstrar que Franz Karl Biberkopf é uma segunda pessoa, ajustada à massa que o carrega nos movimentos incessantes do agitado espaço urbano que é Berlim. 


\section{Os tontos movimentos}

Os tiros que encerram a batalha final do romance de Guimarães Rosa vêm de “profundas profundezas", longe estão, sendo os últimos nas páginas últimas do livro, minguam junto à consciência de Riobaldo. Derradeira tempestade, as mortes de Diadorim e de Hermógenes desacordam o protagonista Riobaldo. Deixemo-nos com ele, "depois das tempestades", acordar:

Ouvi os rogos do menino Guirigó e do cego Borromeu, esfregando meu peito e meus braços, reconstituindo, no dizer, que eu tinha estado sem acôrdo, dado ataque, mas que não estivesse espumado nem babado. Sobrenadei. E, daí, não sei bem, eu estava recebendo socorro de outros - o Jacaré, Pacamã-de-Prêsas, João Curiol e o Acauã -: que molhavam minhas faces e minha boca, lambi a água. Eu despertei de todo - como no instante em que o trovão não acabou de rolar até ao fundo, e se sabe que caíu o raio... (GSV, p. 560).

Estranho ao romance, é momento raro e breve no texto do Grande Sertão: Veredas um Riobaldo assim desacordado. De um tiro inicial, que não se ouve, mas que se lê como anterior à primeira palavra do livro e como motivador da fala que se inaugura, aos tiros finais que são também o silêncio da ausência de Diadorim, tagarela Riobaldo, colocando em ação os signos de uma agitada trajetória rememorada. "Para trás, não há paz”, afirma Riobaldo (GSV, p. 42).

Faz-se notar na fala de Riobaldo que, para ser contrário ao seu passado, seu presente deseja religiosamente quietude e paz:

O existir da alma é a reza... Quando estou rezando, estou fora de sujidade, à parte de toda loucura. Ou o acordar da alma é que é? (GSV, pp. 568-569).

Todavia, a desejada calmaria que não encontra Riobaldo em seu passado (mesmo que, vez por outra, Riobaldo recorde os eventos e os lugares, as pessoas, as palavras e as coisas de suas "velhas alegrias", os campos floridos de seus tranqüilos momentos: uma "brisbrisa", um manuelzinho-da-crôa, Nhorinhá "vestida de vermelho", Otacília "no 
enquadro da janela", Diadorim “duro sério, tão bonito, no relume das brasas” etc.) também não se dá em seu presente, quando os conflitos de outrora rememorados, suas inquietudes e inseguranças afirmadas, assombram-no. As boas lembranças, embora existam, não aliviam o protagonista Riobaldo, já que convivem, no presente de sua fala, misturadas com o medo e a frustração que resultam dos seus anos de jagunço em atividade.

Riobaldo contudo, na revisão de seu passado, faz do seu desejo de paz coisa atual e passada, como se esse sentimento, que tão caro lhe é, sempre o houvesse acompanhado:

Mesmo com a minha vontade toda de paz e descanso, eu estava trazido ali, no extrato, no meio daquela diversidade, despropósitos, com a morte da banda da mão esquerda e da banda da mão direita, com a morte nova em minha frente, eu senhor de certeza nenhuma (GSV, p. 334).

Mas, se ao iniciarmos nosso texto demos atenção ao instante imóvel e desacordado de Riobaldo, procuramos com isso evidenciar que em sua trajetória o ritmo é outro, combinando sua fala com a constante movimentação e a pouca paz de sua andeja vida. A trajetória de Riobaldo, que, como já notamos, elege dúvidas e incertezas, inscreve-se sobre movediço solo, sendo a fala que a narra operante, simultaneamente o solo e o movimento.

Quando o leitor do Grande Sertão: Veredas depara com a imagem de um Riobaldo fora de si, sem acordo, ainda lhe resta, porém, a sensação de que nem tudo parou, pois não se cala o Riobaldo narrador, sobrevivendo a fala do protagonista à morte de Diadorim. Como em Grande Sertão: Veredas é o próprio Riobaldo quem narra a sua história, em nenhum momento nos distanciamos dele, e mesmo quando the ocorre a maior de suas perdas, o abalo que se segue não o silencia, mas, ao lhe atingir profundamente, incentiva a fala que é o texto de todo o romance. Em Berlin Alexanderplatz outro é o caso.

Franz Biberkopf não enfrenta menores crises que as de Riobaldo: enganam-no, perde um de seus braços e também a mulher a quem mais amou. Todos esses momentos 
críticos perturbam o ânimo do protagonista, afastando-o de suas atividades ao lhe atrapalhar em sua usual movimentação pelo centro urbano berlinense em busca de uma vida "decente".

Quando, por exemplo, Franz Biberkopf sofre o primeiro dos três golpes que o atingem durante o romance, que é a traição de Otto Lüders, ele se isola de seus conhecidos e do mundo, passando a viver recluso sem mais praticar o comércio de que se ocupava. "Não é da conta de ninguém o que eu faço. Se quero ficar cochilando, cochilo até depois de amanhã sem me mexer...” $\left(B A, t b\right.$, p. 119) ${ }^{86}$. Também quando Biberkopf, vítima de sua ingenuidade, encontra-se envolvido na ação criminosa que lhe tira um de seus braços, deixa ele mais uma vez de agir, convalescendo em casa de amigos enquanto nega o ocorrido e ignora aqueles que esperam dele alguma resposta aos envolvidos no incidente. Franz Biberkopf, assim como Riobaldo, quer a paz.

A paz e a tranqüilidade de uma vida "decente", contudo, não lhe atingem tão facilmente quanto os golpes que ele sofre. Franz Biberkopf permite que passem os dias de sua vida com seguidos descuidos, e confere assim à sua história uma tonalidade que contrasta fortemente com o seu desejo de paz. E, desconhecendo a paz, assim como desconhece a sensatez, Biberkopf apenas entrevê algum sossego quando lhe tocam os infortúnios que impedem a circulação incessante que o caracteriza. Logo, nunca é um verdadeiro estado de tranqüilidade que o atinge, mas a calmaria inquieta de um ser entrevado por seus erros.

Curiosamente, como segurança e conforto, parece colocar-se no romance de Döblin o presídio de Tegel, local onde Biberkopf esteve preso pelo assassinato de sua antiga companheira Ida. Muita vez, quando complicam as coisas para ele, ativam-se em sua memória as imagens de seu antigo cotidiano de prisioneiro:

O que fazer? E então a coisa o atravessa e ele fecha a boca com força: esse é meu castigo, eles me soltaram, os outros ainda estão descascando batatas na prisão junto ao

\footnotetext{
86 "Wen geht das was an, was ich mache. Wenn ich dösen will, döse ich bis übermorgen auf einem Fleck" (BA, p. 136).
} 
grande monte de lixo, e eu tenho de pegar o bonde, maldição, não era tão mau assim por lá $(B A, t b, \text { p. 106) })^{87}$.

Mas Tegel, lembranças de Biberkopf e passado próximo ao livro, ocupa mesmo é o espaço que antecede o início da narrativa, significando assim também a ausência do livro e de sua ação. "Começa agora a pena", lê-se no primeiro capítulo do romance $(B A$, $t p$, p. 13$)^{88}$, e o outrora trabalhador do transporte de mobílias tem de encarar sua vida na cidade, despedindo-se dos "bons tempos" em que o seu isolamento era bem assistido. A vida, movente, agita-se. "Der Rosenthalerplatz unterhält sich” ( $B A$, p. 51).

Privado de suas andanças, o Franz Biberkopf que se esconde no quarto de sua residência ou na casa de seus amigos, ou que é recolhido em um hospital ou em um presídio, destaca-se aparentemente como uma personagem ferida em sua propriedade. Se os períodos críticos do incauto Franz Biberkopf, ao aproximarem-no da morte, colocamno entre quatro paredes, devemos notar com isso que, por outro lado, a sua vida participa usualmente do vaivém que anima as ruas berlinenses e do trânsito que sua existência precária faz necessário, já que lhe é ordinário sua incessante troca de mulheres, amigos, empregos, estados psíquicos e físicos.

Se no Grande Sertão: Veredas, como já observamos, em nenhum momento nos distanciamos de Riobaldo, o mesmo não se dá no Berlin Alexanderplatz. O romance de Döblin alterna constantemente as várias vozes que o narram, resultando disso inúmeros momentos no romance em que perdemos o protagonista Franz Biberkopf. Quando Reinhold assassina Mieze, por exemplo, Franz Biberkopf não nota de imediato que isso ocorreu, ignora que mais uma vez fora apunhalado, e enquanto o caso caminha para o seu desvendamento, logo no primeiro capítulo do livro seguinte (oitavo), surgem emparelhando esse acontecimento tão significativo à trama a notícia de uma luta de boxe, um discurso sobre o modo pelo qual as plantas se protegem do frio, um comentário sobre a falta de importância da publicação de algumas outras notícias, uma mesa de bar com

\footnotetext{
87 "Was soll man machen? Und da gießt es durch ihn, und er beißt seinen Mund zu: Das ist die Strafe, mich haben sie rausgelassen, die andern buddeln noch Kartoffeln hinter dem Gefängnis an dem großen Müllberg, und ich mu $\beta$ die Elektrische fahren, verflucht, es war doch ganz schön da" (BA, p. 120).

88 "Die Strafe beginnt" (BA, p. 13).
} 
pessoas que contam piadas etc. (BA, pp. 397-399). Semelhante, porém, ao Grande Sertão: Veredas, no Berlin Alexanderplatz, é a continuidade da narrativa que não tem o seu discurso abalado por um Franz Biberkopf fora de cena, como observamos igualmente no caso daquele Riobaldo desacordado. No romance de Döblin, a eleição de um protagonista como Franz Biberkopf não quer excluir da narrativa os inúmeros outros anônimos e seus discursos que assim como ele freqüentam Berlim. Assim, se a existência da cidade não depende exatamente da existência individual de Biberkopf, e o livro de Döblin constrói a sua narrativa com ambos, mesmo com um Franz Biberkopf morto, poderíamos ainda ter algumas páginas do Berlin Alexanderplatz indiferentes ao protagonista.

Revela-se aqui, com a questão que leva em conta as relações de proximidade e distância entre leitores e protagonistas, que os romances de Döblin e de Guimarães Rosa diferenciam-se no modo como narram suas histórias. Não obstante tal distinção entre as narrativas dos dois romances, continuaremos o nosso texto com a atenção voltada às movimentações dos dois protagonistas, sem, por ora, insistirmos nas diferenças de seus enunciados, já que ainda esperamos demonstrar, com o desenvolvimento de nosso trabalho, que essas mesmas diferenças são também fatores de aproximação dos dois romances.

Riobaldo, a certa altura da narrativa, afirma que o sujeito que "é pobre, pouco se apega, é um giro-o-giro no vago dos gerais, que nem os pássaros de rios e lagoas" ( $G S V$, p. 41). Sendo pobres, de "vida muito repagada" (GSV, p. 97), e vivendo os dois em contínua movimentação, "perna direita, perna esquerda, perna direita, perna esquerda" $(B A, t b$, p. 123), Riobaldo e Franz Biberkopf são ambos sujeitos provisórios, traço esse que é fundamental em suas personalidades ${ }^{89}$. As trajetórias dos dois protagonistas, que privilegiamos em nosso trabalho, demonstram que ambos são portadores de uma vida bastante movimentada, jornadeando um pelo sertão em seu ofício de jagunço, enquanto caminha o outro com seus empregos temporários pelo centro berlinense. Não bastasse o

89 “[...] fazendeiro-mór é sujeito da terra definitivo, mas que jagunço não passa de ser homem muito provisório" (GSV, p. 390). O Riobaldo no qual demonstramos nosso interesse, neste momento, é o que se diferencia nas páginas do romance de Guimarães Rosa como jagunço, apesar de ocupá-las, as páginas, nas palavras de um Riobaldo fazendeiro, que é quem, como narrador, movimenta o Riobaldo "provisório" ao recordar sua história. 
vaivém que suas atividades exigem, também os sentimentos que se apoderam dos dois são significativamente transitórios. A "natureza da gente é muito segundas-e-sábados", como diz Riobaldo (GSV, p. 172).

Ao nos determos, primeiramente, nas histórias de Riobaldo e de Franz Biberkopf, verificamos que desde os seus momentos iniciais pouco nelas está livre deste caráter transitório que procuramos acentuar. Riobaldo ainda moço, insatisfeito na propriedade de Selorico Mendes, não se deixa ali estar, apesar do conforto, mas coloca-se em movimento e parte em direção ao Curralinho, como já notamos. Daí em diante, inicialmente com o bando de Zé-Bebelo, e depois sob a chefia de Joca Ramiro, transita constantemente enquanto jagunço em guerra, que em suas palavras é “o constante mexer do sertão" ( $G S V$, p. 341). Já Urutú-Branco, chefe de seu bando, Riobaldo muito vaga pelo sertão, confuso de sentimentos, sem mesmo saber esclarecer aos seus companheiros o destino deles todos que seria posteriormente a travessia do Liso do Sussuarão. "Aonde é que jagunço ia? À vã, à vã” (GSV, p. 421). Ou seja, até mesmo quando é incerto o rumo de suas andanças, o trânsito de Riobaldo e de seus jagunços é ininterrupto. "Mesmo deitado, eu sentia que estava caminhando, galopando”, reconhece Riobaldo (GSV, p.422), dando-nos a entender que a maior constância da vida de um jagunço é o seu viver nômade, a sua inconstância de homem andejo que não se deixa fixar em parte alguma. "Homem anda como anta: viver vida. Anta é o bicho mais boçal..." (GSV, p. 525).

Não é outro o modo pelo qual vive Franz Biberkopf, que anda pelas ruas de Berlim à procura de trabalho, ou então a trabalho, como vendedor ambulante; à procura de uma mulher ou, então, à procura de um bar que possa aliviar suas dores; se envolvido numa ação criminosa, anda Biberkopf também, e até mesmo quando nada o ocupa, caminhar pode o ajudar, incluindo-o na vida citadina. Mais que uma escolha, a movimentação de Franz Biberkopf é uma condição que se lhe impõe, pois adaptar-se como cidadão, deixado o presídio de Tegel para trás, significa enfrentar as ruas com seus transeuntes, bondes, automóveis e tudo o mais que nelas se movimenta, incluso aí os mais diversos discursos que numa grande cidade circulam sem cessar. Também superar suas crises, nas quais se confina Franz Biberkopf entre quatro paredes, como já observamos, implica adentrar o trânsito de Berlim e colocar-se lado a lado com os pedestres anônimos que dão forma à cidade: 
Para fora do buraco, para a rua fria. Havia muita gente. Uma quantidade incrível no Alex, todo mundo ocupado! Parece que não podem viver sem isso. Franz Biberkopf correu com eles, revirando os olhos para a direita e para a esquerda. Como quando um cavalo escorrega no asfalto molhado e leva um pontapé com a bota na barriga e tenta se levantar, sai aos tropeções, e depois dispara feito louco $(B A, t b, \text { p. 148 })^{90}$.

Constantemente, o discurso do Berlin Alexanderplatz associa o caminhar de Franz Biberkopf a um marchar, como se a todo momento que o protagonista enfrenta as ruas, tomasse ele, contra a sua vontade, parte de uma guerra:

Franz Biberkopf marcha pelas ruas, passo firme, esquerda direita, esquerda direita, não vou alegar cansaço, nada de botequim, não vou beber, veremos, chegou uma bala voando, vamos ver, apanho eu com ela, fico deitado, esquerda direita, esquerda direita, esquerda direita. Rufar de tambores e batalhões. Finalmente ele respira $(B A, t b, \mathrm{p}$. $276)^{91}$.

Pudesse, e alguma inteligência melhor auxiliasse Franz Biberkopf, talvez ele evitasse uma parte dos conflitos que o envolvem, mas, existindo as ruas, sempre alguma coisa caminha ao lado do nosso protagonista e, sendo ele muita vez boçal como uma anta, para usar dos termos de Riobaldo, acontece geralmente de ele não poder escapar de seus infortúnios e ver-se num campo de batalha em guerra, tal como o personagem de Guimarães Rosa. "Vida, e guerra é o que é: êsses tontos movimentos, só o contrário do que assim não seja” (GSV, p. 217).

\footnotetext{
90 "Raus aus dem Loch, auf die kalte Straße. Viel Menschen. Kolossal viel Menschen gibts am Alex, haben alle zu tun. Wie dies nötig haben. Der Franz Biberkkopf lief Ihnen, der drehte die Augen rechts und links. Als wenn ein Gaul ausgerutscht ist auf dem nassen Asphalt und kriegt einen Tritt in den Bauch mitm Stiebel und krabbelt hoch, und nun karriolt er los und läuft wie verrückt" (BA, p. 172).

91 "Da marschiert Franz Biberkopf durch die Straßen, mit festem Schritt, links rechts, links rechts, keine Müdigkeit vorschützen, keine Kneipe, nichts saufen, wir wollen sehen, eine Kugel kam geflogen, das wollen wir sehen, krieg ich sie, liege ich, links rechts, links rechts. Trommelgerassel und Bataillone. Endlich atmet er auf" (BA, p. 320).
} 
Antes havíamos observado que não apenas os "corpos" de nossos protagonistas estão em constante movimento, mas também os sentimentos que lhe pertencem têm aspectos transitórios:

O senhor... Mire veja: o mais importante e bonito, do mundo, é isto: que as pessoas não estão sempre iguais, ainda não foram terminadas - mas que elas vão sempre mudando. Afinam ou desafinam. Verdade maior. É o que a vida me ensinou ( $G S V$, p. 24).

A noção defendida por Riobaldo de que as pessoas "vão sempre mudando" traz mais uma vez ao nosso texto a questão do "desenvolvimento" das personagens que estudamos ao considerarmos suas trajetórias. O Riobaldo para quem "viver é um descuido prosseguido" (GSV, p. 68), no presente de sua fala depara com uma série de problemas que emergem enquanto ele recupera o seu passado. Para os problemas que assim surgem em sua fala, Riobaldo não parece querer a ajuda de soluções definitivas, preferindo deixar sem respostas as suas dúvidas, pois toda e qualquer explicação, em seu caso, seria uma simplificação indesejada ${ }^{92}$. Se em seu presente de jagunço aposentado, inquietam-no questões existenciais que ora o fazem afirmar uma coisa, ora outra, sustentando, por exemplo, a tensão entre o ser e o não-ser do diabo, e, conseqüentemente, colocando em dúvida a validade de seu pacto e do seu compromisso de homem crente, em seu passado de jagunço em atividade, como nos faz acreditar a sua voz, menores não eram as suas inseguranças.

Marcando-lhe profundamente a lembrança de Diadorim, o ser duplo que essa donzela guerreira é, sendo simultaneamente homem e mulher, delicadeza e força, projeta em Riobaldo a sua ambigüidade. Assim, absorvido pelo que aprendeu com Diadorim, a educadora maior de seus sentimentos, Riobaldo transfere a ambigüidade de sua amada para todas as coisas por ele observadas. "Melhor, se arrepare: pois, num chão, e com igual formato de ramos e fôlhas, não dá a mandioca mansa, que se come comum, e a

\footnotetext{
${ }^{92}$ Se Riobaldo, de vez em vez, pede o auxílio do visitante "instruído" a quem ele dirige a sua fala, isso contudo não demonstra uma verdadeira vontade de ter esclarecidas as suas questões, já que no texto do Grande Sertão: Veredas não há espaço para o seu interlocutor, que está a todo momento emudecido pela voz de Riobaldo. "Ah, o que eu prezava ter era essa instrução do senhor, que dá rumo para se estudar dessas matérias..." (GSV, p. 221). Deste modo, o uso que faz Guimarães Rosa de um citadino "instruído" em silêncio, pode ser encarado como estratégia do autor, que assim não quer ver reduzidas as indagações de seu protagonista.
} 
mandioca-brava, que mata?" (GSV, p. 12). Com a desconfiança entre os seus sentimentos mais caros, Riobaldo narra a sua trajetória entre Deus e o diabo, entre o homem e a mulher, entre o legal e o ilegal e assim por diante, sem deixar de lado o trânsito de suas opiniões. "Eu era dois, diversos?" (GSV, p. 460) ${ }^{93}$. Por exemplo, a certa altura, em meio aos outros jagunços, após um momento em que se ocupara em observar o Hermógenes, reflete Riobaldo sobre a sua relação com os seus companheiros de profissão:

Então, eu era diferente de todos ali? Era. Por meu bom. Aquêle povo da malfa, no dia e noite de relaxação, brigar, beber, constante comer. - "Comeu lôbo?" E vozear tantas asneiras, mesmo de Diadorim e de mim já pensavam (GSV, p. 164).

E logo abaixo, repetindo a sua questão com outra formulação, decide-se Riobaldo pelo contrário: "E eu era igual àqueles homens? Era" (GSV, p. 164). Essa alternância de opiniões de Riobaldo demonstra que o personagem inquisitivo que ele é não assume posturas excludentes, sendo usualmente uma coisa e outra simultaneamente ${ }^{94}$. "Acho que eu não era capaz de ser uma coisa só o tempo todo" (GSV, p. 442). Coragem e medo que, como já vimos, estão entre as maiores preocupações de Riobaldo, também exemplificam as suas variações: "Eu cá não madruguei em ser corajoso; isto é: coragem em mim era variável" (GSV, p. 45). E assim, moventes como seus passos, os sentimentos de Riobaldo transitam de um lado para o outro, pois "[...] manter firme uma opinião, na vontade do homem, em mundo transviável tão grande, é dificultoso. Vai viagens imensas" (GSV, p. $501)$.

De acordo com Riobaldo, o "que nesta vida muda com mais presteza: é lufo de noruega, caminhos de anta em setembro e outubro, e negócios dos sentimentos da gente" (GSV, p. 435). Mas Riobaldo "nunca tinha certeza de coisa nenhuma", como afirma em seu discurso (GSV, p. 354). Resta-nos com isso verificar se a sua observação mantém a validade no caso de Franz Biberkopf.

\footnotetext{
${ }^{93}$ Lembre-se o verso do Fausto de Goethe: "Zwei Seelen wohnen, ach! in meiner Brust". Cf. GOETHE, Johann Wolfgang von. Fausto - Uma Tragédia - Primeira Parte. São Paulo: Ed. 34, 2004, p. 118.

${ }^{94}$ Embora sentimentos e opiniões contrárias coexistam em Riobaldo, vale lembrar que o seu desejo expresso é outro: "Que isso foi o que sempre me invocou, o senhor sabe: eu careço de que o bom seja bom e o ruím ruím, que dum lado esteja o prêto e do outro o branco, que o feio fique bem apartado do bonito e a alegria longe da tristeza! Quero os todos pastos demarcados..." (GSV, p. 210).
} 
Franz Biberkopf, dada sua ingenuidade, talvez seja capaz de demonstrar até com maior nitidez a mobilidade de seus sentimentos. O imediatismo do protagonista de Berlin Alexanderplatz chega a impressionar, e não raro o encontramos, sem maiores reflexões, saltando bruscamente de um estado emocional a outro ${ }^{95}$. Seus sentimentos são aparentemente simples: ele pode ser violento, se irritado, ou fraternal e amoroso, se alegre. Dono de um humor inconstante, Franz Biberkopf tem entre as suas mais significativas questões o controle de seu ânimo. Com a sua antiga companheira, Franz Biberkopf foi extremamente violento e descontrolado, e obteve assim seus anos de reclusão em Tegel. Liberto em Berlim, a vida que se lhe recomeça exige dele prudência e sobriedade. No entanto, como já observamos ao nos determos em sua trajetória, não pôde o ex-presidiário lidar sobriamente com todas as dificuldades que lhe cruzaram o caminho.

Numa de suas primeiras situações difíceis, que é uma cena do livro em que, por razões políticas, freqüentadores de um bar implicam com sua figura, surge prontamente a questão do autocontrole. Franz Biberkopf ali sabe que não deve se meter em confusão, travando então uma complexa luta com os seus impulsos para não avançar contra os freqüentadores:

$\mathrm{Eu}$ me entreguei, pensa Franz, agarrou-se na janela diante da veneziana, vou estourar, homem, tomara que não me agarrem; quero ficar em paz com todos, mas vai haver uma desgraça, tomara que ele não seja idiota ao ponto de me agarrar $(B A, \mathrm{tb}, \mathrm{p}$. $85)^{96}$.

Claramente perturbado em seu equilíbrio, Franz Biberkopf deixa o bar para evitar maior confusão e cumprir com o seu desejo de ser um homem "decente". É preciso mencionar que este seu desejo o inclina a participar inconseqüentemente das idéias de paz e ordem que orientaram a direita nazista, desconforto que fratura a amizade de Franz Biberkopf com seu velho amigo Georg Dreske na situação acima reportada. A exemplo dessa situação, poderíamos ainda localizar no livro outros momentos semelhantes em que o autocontrole de Franz Biberkopf é acionado não sem transtornos. Contudo, tratando

\footnotetext{
${ }^{95}$ Vale mencionar que "emoção" deriva do vocábulo latino motio, implicando "movimento", "ação".

96 "Ich hab mich ergeben, denkt Franz, hat sich ans Fenster geklemmt vor der Jalousie, hier geh ich los, wenn die mich blo $\beta$ nicht anfassen; ich bin allen gut, aber es gibt ein Malheur, wenn der blo $\beta$ nicht so dämlich ist, mich anzufassen" ( $B A$, p. 97).
} 
aqui da transitoriedade dos sentimentos de Biberkopf, mais proveitoso será observar como são paradoxais as ações da personagem que os têm por guia.

Ao ocuparmo-nos da trajetória de Franz Biberkopf, mencionamos a situação em que ele esteve envolvido no início de sua amizade com Reinhold, que era a curiosa troca de amantes que unia os dois. Constatamos também, que a mudança de opinião de Franz Biberkopf, que decide interromper a permuta, causou-lhe grande aborrecimento e a perda de um de seus braços. Mas Franz Biberkopf parece nutrir sentimentos iguais pela sua amada Mieze e por Reinhold, insistindo na amizade deste, enquanto nós leitores, desde o final do quinto livro do Berlin Alexanderplatz, que é o momento do acidente que lhe tira o braço, sabemos que a figura sombria de Reinhold não pode lhe fazer bem. Como conseqüência de sua relação cega com Reinhold, Franz Biberkopf, "um espírito que perdoa e concilia", facilita no sétimo livro do romance que a sua pequena Mieze seja assassinada por Reinhold.

A ambivalência de Franz Biberkopf, endossada por sua ingenuidade, não se restringe às suas relações fraternais, mas atinge também suas esferas política, jurídica e econômica. Franz Biberkopf é contraditório, vende "jornais völkisch" e faz uso de uma braçadeira com a suástica, mas sustenta amizade e admiração por homens de posturas políticas outras, isso quando não prefere afirmar que a política não lhe diz respeito. " $\mathrm{E}$ mais uma vez não existe ninguém mais contente que o nosso Franz Biberkopf, que manda a política para o diabo" $(B A, t b, \text { p. } 270)^{97}$. Aliás, em sua noção de "decência", vender jornais nazistas parece valer para Franz Biberkopf tão pouco quanto comercializar prendedores de gravatas ou cadarços, desde que disso resulte para ele alguns trocados. Podemos verificar igualmente que o mesmo oscilar que caracteriza a postura política de Franz Biberkopf faz com que ele não consiga, até que se alcancem as últimas páginas do livro, estabelecer o seu lugar social numa estabilidade econômica ou jurídica. Biberkopf está durante todo o livro entre o emprego e o desemprego, entre o "decente" e o criminoso, alternando os seus desejos e confundindo-se entre eles.

\footnotetext{
97 "Und wieder gibt es nichts Zufriedeneres als unsern Franz Biberkopf, der die Politik zum Deibel schickt" (BA, p. 314).
} 
Do mesmo modo que transitam as pernas, os sentimentos e as posições de Franz Biberkopf pelas ruas berlinenses, podemos pensar que ali circulam as mercadorias que lemos no livro anunciadas, os discursos anônimos que noticiam fatos públicos e privados etc. Ao escrever seu Berlin Alexanderplatz, Alfred Döblin não ignora que o trânsito de pessoas, carros, bondes, mercadorias e informações constitui parte importante da paisagem de uma grande cidade. Sem deixá-lo de lado, a narrativa do Berlin Alexanderplatz parece querer a mesma complexa linguagem com a qual a cidade se faz legível. Neste sentido, Berlin Alexanderplatz não é uma "expressão" da cidade, entendendo, aqui, "expressão" como uma prática de texto que demonstraria o estado anímico de um autor, sujeito particular (a fascinação, o susto, a paixão, o medo num lamento ou numa canção de amor), em sua relação específica com um objeto (no caso, o tema da cidade moderna). Antes, o romance de Döblin é uma narrativa que procura com maior objetividade aproximar a estrutura urbana de seu discurso, e para isso coloca em cena os elementos flutuantes e variáveis de um cotidiano metropolitano: discursos políticos, questões econômicas, anúncios de produtos e serviços, textos jornalísticos, estatísticas, presenças míticas e também personagens inconstantes e passageiros, entre eles o protagonista Franz Biberkopf.

Não apenas no Berlin Alexanderplatz, mas também no Grande Sertão: Veredas, às qualidades transitórias dos protagonistas que ressaltamos até então em nosso trabalho correspondem os seus enunciados com igual mobilidade. É indispensável, nesse caso, pensá-los em conjunto.

Observar o trânsito acidentado nas andanças de Biberkopf, assim como as viagens pelo sertão de Riobaldo, pode ser interessante quando se nota que a fala possui semelhanças com o "ato de caminhar". Afirma Michel de Certeau que o

[...] ato de caminhar está para o sistema urbano como a enunciação (o speech act) está para a língua ou para os enunciados proferidos. Vendo as coisas no nível mais elementar, ele tem com efeito uma tríplice função 'enunciativa': é um processo de apropriação do sistema topográfico pelo pedestre (assim como o locutor se apropria e assume a língua); é uma realização espacial do lugar (assim como o ato de palavra é uma realização sonora da língua); enfim, implica relações entre posições diferenciadas, ou 
seja, 'contratos' pragmáticos sob a forma de movimentos (assim como a enunciação verbal é 'alocução', 'coloca o outro em face' do locutor e põe em jogo contratos entre colocutores $)^{98}$.

Ao movimento do que é narrado, nos livros de Döblin e de Guimarães Rosa, podemos somar o movimento do que narra: os dois fazem a mímesis do movimento mesmo da cidade e do sertão, no grande movimento da linguagem. Por exemplo, no Berlin Alexanderplatz, às barreiras que Franz Biberkopf tem de transpor em sua trajetória com esforço estéril correspondem interrupções de elementos discursivos estranhos ao texto da trama de nosso protagonista. Os caminhos interditados para Franz Biberkopf encontram no texto que os narra semelhante situação quando entrecruzam a história do protagonista fragmentos discursivos que dela não participam diretamente, como pode ser notado no início do segundo livro do romance, onde após um relato das condições de Berlim naquele momento, que incluem notícias bastante diversificadas, não se obtêm informações de Franz Biberkopf, sem antes, por cinco páginas, demorar-se o texto nas histórias de dois amigos quaisquer que comentam o desemprego de um deles e no caso de uma garota que se encontra furtivamente com um senhor de meia-idade $(B A, t b, \mathrm{pp}$. 4852). Também, sem que se fixe num determinado assunto, o texto de Döblin repetidas vezes transita num mesmo trecho da narrativa por elementos deveras diversificados. $\mathrm{O}$ trecho a seguir, apesar de longo, é talvez o melhor exemplo dessa estratégia de que Döblin faz uso:

Lojas de bebidas, restaurações, mercadinhos de fruta e verdura, produtos coloniais e especiarias, transportes, pinturas decorativas, confecção feminina, produtos de farinha e moinhos, garagens, corpo de bombeiros: a vantagem da mangueira a motor é a construção simples, fácil manejo, pouco peso, tamanho reduzido. - Camaradas alemães, nunca o povo foi enganado de maneira mais infame, nunca uma nação foi traída de maneira mais degradante e injusta como o povo alemão. Recordam ainda como Scheidemann, a $1^{\circ}$ de novembro de 1918 , prometeu paz, liberdade e pão no peitoril da janela do Reichstag? E como cumpriram a promessa? Equipamento para canalizações, companhia de limpeza de janelas, sono é remédio, cama de paraíso Steiner. - Livraria, a

${ }^{98}$ Cf. CERTEAU, Michel de. A Invenção do Cotidiano. $6^{\mathrm{a}}$ ed. Petrópolis: Vozes, 2001, p. 177. 
biblioteca do homem moderno, nossas edições completas e autores e pensadores influentes reúnem-se e constituem a biblioteca do homem moderno. São os grandes representantes da vida intelectual européia. A lei de proteção do inquilinato é um pedaço de papel. Os aluguéis sobem constantemente. A classe média trabalhadora é atirada ao chão e sufocada, o oficial de justiça tem colheita farta. Pedimos créditos públicos até 15.000 marcos à pequena indústria, proibição imediata de todas as hipotecas dos pequenos industriais. - É desejo e dever de toda mulher preparar-se para a hora do parto. Todos os pensamentos e emoções da futura mãe giram em torno do nascituro. Então a escolha da bebida certa para a futura mãe é particularmente importante. A legítima cerveja Engelhardt-Caramelo possui como nenhuma outra bebida as qualidades do bom sabor, da força nutritiva, é digestiva, tem efeito refrescante. - Cuide do futuro de seu filho e de sua família com um seguro de vida de uma seguradora suíça, Caixa de Pensões de Zurique. - O seu coração vai pular de alegria quando você tiver um lar mobiliado com os famosos móveis Höffner. Tudo o que você sonhou sobre conforto é superado por essa realidade nunca antes imaginada. Embora os anos passem, essa visão permanece agradável, e sua durabilidade e utilidade prática são uma renovada alegria $(B A, t b, \mathrm{pp}$. $115-116)^{99}$.

99 "Destillen, Restaurationen, Obst- und Gemüsehandel, Kolonialwaren und Feinkost, Fuhrgeschäft, Dekorationsmalerei, Anfertigung von Damenkonfektion, Mehl und Mühlenfabrikate, Autogarage, Feuersozietät: Vorzug der Kleinmotorspritze ist einfache Konstruktion, leichte Bedienung, geringes Gewicht, geringer Umfang. - Deutsche Volksgenossen, nie ist ein Volk schmählicher getäuscht worden, nie wurde eine Nation schmählicher, ungerechter betrogen als das deutsche Volk. Wißt ihr noch, wie Scheidemann am 9. November 1918 von der Fensterbrüstung des Reichstags uns Frieden, Freiheit und Brot versprach? Und wie hat man das Versprechen gehalten! - Kanalisationsartikel, Fensterreinigungsgesellschaft, Schlaf ist Medizin, Steiners Paradiesbett. - Buchhandlung, die Bibliothek des modernen Menschen, unsere Gesamtausgaben führender Dichter und Denker setzen sich zusammen zur Bibliothek des modernen Menschen. Es sind die großen Repräsentanten des europäischen Geisteslebens. - Das Mieterschutzgesetz ist ein Fetzen Papier. Die Mieten steigen ständig. Der gewerbliche Mittelstand wird auf das Pflaster gesetzt und auf diese Weise erdrosselt, der Gerichtsvollzieher hält reiche Ernte. Wir verlangen öffentliche Kredite bis zu 15.000 Mark an das Kleingewerbe, sofortiges Verbot aller Pfändungen bei Kleingewerbetreibenden. - Der schweren Stunde wohlvorbereitet entgegenzugehen ist Wunsch und Pflicht jeder Frau. Alles Denken und Fühlen der werdenden Mutter kreist um das Ungeborene. Da ist die Auswahl des richtigen Getränks für die werdende Mutter von besonderer Wichtigkeit. Das echte EngelhardtKaramelmalzbier besitzt wie kaum ein anderes Getränk die Eigenschaften des Wohlgeschmacks, der Nährkraft, Bekömmlichkeit, erfrischenden Wirkung. - Versorge dein Kind und deine Familie durch Abschlu $\beta$ einer Lebensversicherung einer schweizerischen Lebensversicherung, Rentenanstalt Zürich. - Ihr Herz lacht! Ihr Herz lacht vor Freude, wenn Sie ein mit den berühmten Höffner-Möbeln ausgestattetes Heim besitzen. Alles, was Sie sich an angenehmer Wohnlichkeit erträumten, wird von einer ungeahnten Wirklichkeit übertroffen. Wie auch die Jahre entschwinden, wohlgefällig bleibt dieser Anblick, und ihre Haltbarkeit und praktische Verwendbarkeit erfreuen immer von neuem. -" (BA, pp. 131-132). Até o momento presente, ao citar trechos das traduções do Berlin Alexanderplatz, optamos por não interferir nas escolhas de seus tradutores pois, geralmente, o sentido do texto original está preservado e não é dos objetivos de nosso trabalho fazer comentários sobre as traduções. Em todo caso, na versão em língua portuguesa do trecho acima, facilmente se nota a diferença de data que marca o discurso de Scheidemann. 
O heteróclito acima não deixa de compor de modo interessante, no próprio processo construtivo, sintático e pragmático, o ambiente transtornado de uma grande cidade. Com isso, mais do que afirmar que a narrativa do Berlin Alexanderplatz pratica uma movimentação contínua que se faz homóloga ao trânsito urbano, queremos também observar que, apesar de nesse procedimento Döblin utilizar elementos estranhos à história de Biberkopf, como já mencionamos, os pedaços discursivos que rodeiam a trajetória do protagonista são também significativos para a compreensão de sua vida, uma vez que situam suas atividades no conjunto de experiências que podem ser vivenciadas na Berlim de seus dias. De qualquer modo, a narrativa do romance de Döblin que agrupa em si grande variedade de discursos, não o faz sem a ironia de um narrador que conhece os verdadeiros valores desta barafunda de informações que ocupa o espaço urbano:

O que importa se dois remadores berlinenses se afogam no Danúbio, ou Nungesser cai com seu Weissen Vogel na Irlanda? O que gritam na rua compramos por dez fêniques e jogamos fora, abandonamos em qualquer parte. Queriam linchar o primeiro-ministro húngaro porque ele atropelou um menino camponês com seu carro. Se o tivessem linchado, a manchete diria "Linchamento do primeiro-ministro húngaro na cidade de Kaposvar", o que teria multiplicado a gritaria, os letrados teriam dito lanchar em vez de linchar e teriam rido, os outros oitenta por cento teriam dito: bobagem, de qualquer modo isso não me interessava ou a gente deveria fazer o mesmo por aqui ( $B A$, $t b$, p. 344) ${ }^{100}$.

De grande atualidade, as questões colocadas no romance estão desenvolvidas de tal modo que confluem nele os movimentos de Franz Biberkopf e a movimentação da linguagem que os narra. Por isso também, Alfred Döblin não utiliza exatamente a mesma língua alemã de Goethe, mas prefere em seu texto um forte efeito de oralidade,

\footnotetext{
100 "Was macht es aus, wenn zwei Berliner Paddler in der Donau ertrunken sind, oder Nungesser ist abgestürzt mit seinem 'Weissen Vogel' bei Irland. Was schreien die auf der Straße aus, für 10 Pfennig kauft man es, schmei $\beta$ t es weg, läßt es wo liegen. Den ungarischen Ministerpräsidenten wollten sie lynchen, weil er einen Bauernjungen mit seinen Auto überfahren hat. Wenn sie ihn galyncht hätten, hätte die Überschrift gelautet: 'Lynchung des ungarischen Ministerpräsidenten bei der Stadt Kaposvar', das hätte das Geschrei vermehrt, die Gebildeten hätten statt Lynchungen Lunching gelesen und darüber gelacht, die andern 80 Prozent hätten gesagt: schade so wenig, oder wenn schon, geht mir nichts an, müßte man eigentlich hier auch machen" (BA, p. 398).
} 
aproximando sua escrita dos modos de falar berlinenses de sua época. A ilusão de oralidade que se obtém com esse recurso sugere mais ainda o caráter de mobilidade que encontramos no texto do romance, já que nele se antecipam, a um discurso literário vinculado às normas cultas da língua as liberdades lingüísticas que normalmente se dão na fala. Da mesma forma, o texto de feição não menos móvel do Grande Sertão: Veredas abusa igualmente dos efeitos de oralidade, sobretudo porque todo o romance é apresentado como uma fala, a do protagonista Riobaldo ${ }^{101}$. Cheio de artifícios, o texto de Guimarães Rosa é dotado de uma rica linguagem que já há muito tem sido objeto de estudo daqueles cujo interesse maior está nas experimentações formais do autor, como, por exemplo, o livro de Mary L. Daniel, de $1968^{102}$. Aqui, contudo, restringimos nosso interesse em observar que a linguagem serpentiforme do Grande Sertão: Veredas é mais um dos aspectos que reforçam as movimentações de Riobaldo, como o faz a narrativa do Berlin Alexanderplatz com Franz Biberkopf.

“Ai, arre, mas: que esta minha boca não tem ordem nenhuma” ( $G S V$, p. 22). Arbitrária, a fala operante de Riobaldo não apenas ordena a seu modo a narração de sua história, como também pratica um contínuo deslocamento das normas que determinam o "bom uso" sintático e lexical dos termos da língua portuguesa. Para contar a "matéria vertente" (GSV, p. 96), a narrativa do romance de Guimarães Rosa investe na transformação das palavras que utiliza, adaptando prefixos e sufixos aos termos como lhe convém ("desfalar", “desmim de mim-mesmo", “compertencer", "movimental", “andantemente", "influimento", "noivável”, "raivabundo" etc.), fazendo a junção de outros dois termos para a obtenção de um terceiro ("prostitutriz", "patatrás", "tartamelar" etc.), reduzindo vocábulos (“confa”, "supro" etc.), jogando com a sonoridade da língua nos usos onomatopaicos (o "chochorro mateiro", o "chirilil dos bichos", o "chiim dos grilos" etc.), além de atualizar arcaísmos do idioma na fala de Riobaldo.

Tal como a pedra que Riobaldo guarda consigo a fim de presentear Diadorim, que de início é um topázio (GSV, p. 59), mas em seguida é transformada numa safira (p. 353),

\footnotetext{
${ }^{101}$ Um estudo detalhado da oralidade de Grande Sertão: Veredas pode ser encontrado no livro de Teresinha Souto Ward. Cf. WARD, Teresinha Souto. O Discurso Oral em Grande Sertão: Veredas. São Paulo: Duas Cidades; INL, Fundação Nacional Pró-Memória, 1984.

${ }^{102}$ Cf. DANIEL, Mary L. João Guimarães Rosa: Travessia Literária. Rio de Janeiro: José Olympio, 1968.
} 
sendo ainda depois uma ametista (p. 534), a fala de Riobaldo ganha movimento com as variações que ela apresenta: "vem o pão, vem a mão, vem o são, vem o cão" ( $G S V$, p. 13). Desviando das certezas de um discurso seguro daquilo que afirma, dos trabalhos que a fala caprichosa de Riobaldo efetua sobre a língua portuguesa, resulta como efeito uma espécie de indeterminação que condiz com a sua noção de que a "vida é um vago variado" (GSV, p. 471). Corroboram ainda essa indeterminação os recorrentes momentos em que Riobaldo lança mão de imagens de grande delicadeza poética, que bestam o entendimento dos seus leitores com "coisas que não cabem em fazer idéia" (GSV, p. 201). Por exemplo, frases como: "Vaqueiro pode laçar o lugar do ar?" (GSV , p. 472); "Então, eu vi as côres do mundo. Como no tempo em que tudo era falante, ai, sei” (GSV, p. 142); "Já tenteou sofrido o ar que é saudade?" (GSV, p. 27) etc., imbuem de mistério o texto do romance, e assim, toda a movimentação que há na superfície da narrativa do Grande Sertão: Veredas, similar ao vôo de um pássaro que Guimarães Rosa descreve como "vai sôbre vem sob" (GSV, p. 29), faz também com que dela sejam projetadas conseqüentemente significações profundas que a muitos estudiosos do autor interessam. Nas palavras de João Adolfo Hansen há no enunciado do romance de Guimarães Rosa a "efetuação de um fundo" ${ }^{103}$, ou seja, revela-se, para o leitor que assim queira, essências e substâncias transcendentes com esse movimento que "vai sobre" o texto do Grande Sertão: Veredas e que volta sob a forma de sutis efeitos metafísicos ${ }^{104}$.

Resta ainda notar que na fala falsamente ingênua de Riobaldo encontra-se uma grande variedade de saberes que pertencem ao autor do romance. Deste modo, assim como Berlin Alexanderplatz, Grande Sertão: Veredas possui uma vasta variedade de vozes, unificadas em seu caso nos movimentos da voz de Riobaldo. Estão presentes lado a lado no romance de Guimarães Rosa o imaginário sertanejo, sua tradução urbana de longa tradição em nosso país, a religiosidade católica ou kardecista, autores como Plotino, além dos amplos conhecimentos lingüísticos do autor, atualizando temporalidades diversas e dispondo conteúdos vários. Em meio a essa pluralidade, configura-se uma narrativa arbitrária que tem a capacidade de adequar ao seu modo tudo

\footnotetext{
${ }^{103}$ Cf. o texto de Hansen citado na nota 43, p. 71 e seguintes.

${ }^{104}$ Entre os estudos que privilegiam tais interpretações, destacamos aqui os de Francis Utéza e de Heloísa Vilhena de Araújo. Cf. UTÉZA, Francis. JGR: Metafísica do Grande Sertão. Trad. de José Carlos Garbuglio. São Paulo: Edusp, 1994; ARAÚJO, Heloísa Vilhena de. O Roteiro de Deus: Dois Estudos sobre Guimarães Rosa. São Paulo: Mandarim, 1996.
} 
aquilo que lhe convém, experimentando a verossimilhança e a unidade que disso tudo resultam.

Com discursos que não se diferenciam da variedade e da transitoriedade das histórias narradas, mas que as produzem ao transformarem discursos distantes em próximos, transitando constantemente entre uma coisa e outra, Grande Sertão: Veredas e Berlin Alexanderplatz confundem significações e geram sentidos múltiplos. Como nota Klaus Scherpe, quando Döblin recorre às tradicionais referências simbólicas da cidade (prostituta, selva, matadouro), aos diálogos com o texto bíblico (Jó, Jeremias, Isaac), aos eventos marcados com a presença de elementos naturais sugestivos (vento, floresta), e também à estadia de Franz Biberkopf num sanatório como momento de transformação do velho em "novo Franz", garante-se para o conjunto que se constrói de modo não orgânico possíveis unidades de sentido ${ }^{105}$. Assim, numa Berlim babilônica, a saída do presídio de Tegel, por exemplo, pode ser lida num parentesco com a tradição ali presente, ou seja, pode ser a expulsão de Franz Biberkopf do Éden; o "sacrifício" do protagonista encontrará igualmente no texto os animais do episódio do matadouro; Franz Biberkopf pode ainda assemelhar Jó ou competir com os heróis da mitologia grega; a figura sombria de Reinhold pode ser associada às repetidas frases que anunciam o "ceifeiro" presente etc. Todavia, textos que assim como o Berlin Alexanderplatz ordenam uma significativa multiplicidade de elementos terminam por comprometer a eleição de uma unidade de sentido único que se forje com associações mais ou menos evidentes.

É ainda de algum modo complicado apreender do Berlin Alexanderplatz oposições nítidas. Como o texto de Döblin desmancha as identidades possíveis, ele talvez não deva ser lido do mesmo modo que se lê um texto em que se pode opor um verdadeiro a um falso, ou um mal a um bem, a exemplo da análise que faz Volker Klotz do Berlin Alexanderplatz em seu significativo livro Die erzählte Stadt, orientada por uma concepção da representação literária na qual a relação entre o discurso ficcional e a realidade a ele correspondente considera positivamente a validade de oposições previamente concebidas (como aquela entre campo e cidade, sertão e litoral), de um

\footnotetext{
${ }^{105}$ Cf. SCHERPE, Klaus R.. Von der erzählten Stadt zur Stadterzählungen. Der Großstadtdiskurs in Alfred Döblins "Berlin Alexanderplatz". In: Diskurstheorien und Literaturwissenchaft. Jüngen Fohrmann e Harro Müller (orgs.). Frankfurt a. M.: Suhrkamp, 1988, p. 433.
} 
simbolismo compartilhado e de um antropocentrismo, que opõe, por sua vez, indivíduo e massa. Franz Biberkopf, para Klotz, está na condição de Fausto, ou seja, entre os opostos Deus e Mephisto, como uma pessoa em teste, em luta com as condições de Berlim ${ }^{106}$. O problema desse modo de ler o livro de Döblin é que Franz Biberkopf não chega a ser destacado, como um flâneur baudelairiano, do coletivo que o carrega, e nem predomina no livro, apesar de algumas referências míticas, uma fascinação ou um horror, como o de alguns autores expressionistas, ao simbólico monstro urbano. Berlin Alexanderplatz mais afirma, com as montagens de sua narrativa, a perda das relações sociais e morais seguramente identificáveis; Berlin Alexanderplatz mais concilia a simultaneidade conflitante sem abstenções.

Neste ponto de nosso trabalho, esperamos que a observação que fizemos anteriormente, de que as próprias diferenças entre os romances de nosso interesse eram fatores que os aproximavam, esteja mais bem esclarecida. De um modo ou de outro, o que se afirma nos textos do Berlin Alexanderplatz e do Grande Sertão: Veredas, sob a condição de uma linguagem em permanente trânsito, é uma indeterminação que envolve as trajetórias de seus protagonistas de ponta a ponta. As suas narrativas, com grande liberdade e êxito, operam as decisões que julgam estar de acordo com a disposição de seus textos de compreender o espaço complexo de uma grande cidade e de um grande sertão, e com isso, ao elegerem protagonistas como Riobaldo e Franz Biberkopf, permeiam as suas experiências desta vaguidão que não fixa valores seguros e conclusivos. "Eu estou contando assim, porque é meu jeito de contar", diz Riobaldo ao justificar suas escolhas ( $G S V$, p. 95), como também, no livro quinto do Berlin Alexanderplatz, o seu narrador, após discorrer sobre assuntos locais de Berlim, não volta ao seu protagonista sem antes comentar o seu modo de narrar, afirmando assim:

Depois dessa informativa digressão sobre acontecimentos públicos e privados em Berlim, junho de 1928, retornamos a Franz Biberkopf e seu tormento com as moças. É de se supor que também para essas participações só se tenha encontrado um pequeno círculo de interessados. Não discutiremos aqui as causas. Mas de minha parte isso não me

${ }^{106}$ Cf. KLOTZ, Volker. Die erzählte Stadt. Ein Sujet als Herausforderung des Romans von Lesage bis Döblin. München: Carl Hanser, 1969, p. 409. 
impedirá de seguir tranqüilamente os rastros do meu pequeno ser humano em Berlim, centro e leste. Cada um faz o que julga necessário $(B A, t b, \text { p. 180 })^{107}$.

Afinal, como diria Riobaldo, “pão ou pães, é questão de opiniães...” ( $G S V$, p. 9).

107 "Wir kehren nach diesem lehrreichen Exkurs über öffentliche und private Ereignisse in Berlin, Juni 1928, wieder zu Franz Biberkopf, Reinhold und seiner Mädchenplage zurück. Es ist anzunehmen, daß auch für diese Mitteilungen nur ein kleiner Interessentenkreis vorhanden ist. Wir wollen die Ursachen davon nicht erörtern. Aber das soll mich meinerseits nicht abhalten, ruhig den Spuren meines kleinen Menschen in Berlin, Zentrum und Osten, zu folgen, es tut eben jeder, was er für nötig halt” (BA, p. 209). 


\section{Ventos de não deixar se formar orvalho}

Nosso trabalho procurou, até o momento, relacionar os romances de Guimarães Rosa e de Alfred Döblin com vistas a um melhor entendimento de suas particularidades e contribuições para os problemas que envolvem a compreensão do romance moderno. Para tanto, privilegiamos aspectos desses dois romances que os associam à tradição do denominado Bildungsroman, como, por exemplo, a leitura que fizemos das trajetórias de Riobaldo e Franz Biberkopf. Contudo, frisaremos que a terminologia Bildungsroman não é aqui aplicada como categorização dos romances Grande Sertão: Veredas e Berlin Alexanderplatz, ainda que a questão já exista. Não a aplicamos no sentido moralista, como boa educação do leitor de romances, como o fazia Karl Morgenstern ao cunhar a expressão, como também não a aplicamos num sentido de fazer associados os dois romances de nosso estudo a uma modalidade que os compreenderia e explicasse os sentidos ${ }^{108}$. Procuramos, antes, utilizar da discussão em torno do discurso do romance para melhor compreender os casos de Guimarães Rosa e Döblin.

O Bildungsroman é aqui apresentado como uma modalidade romanesca que contribui para a teorização do tipo de romance que se inaugura com Os Anos de Aprendizagem de Wilhelm Meister, ou seja, um tipo simultaneamente louvado e criticado, eficiente e deficiente, romântico e realista, moderno. Sempre muito ampla, a listagem que se pode fazer de romances que participam da modalidade em questão permanece, na maioria das vezes, vaga e discutível. Neste caso, entender a categoria Bildungsroman não significa limitar um grupo de textos passíveis de tal título, mas investigar e compreender os problemas que ela suscita para a prosa de ficção, sobretudo em seu período moderno. Assim, tocar em problemas tais quais os da representação épica e sua intenção de "totalidade", do desenvolvimento de um protagonista e sua unidade de sentido, da linguagem particular de um autor e da idéia de um texto orgânico, como também acercarse dos significados dos romances em jogo nos seus leitores, torna-se fundamental para aquilo que pretendemos. Se encontramos alguma comunidade em textos como os do

${ }^{108}$ Uma melhor elucidação dos problemas que existem no uso da terminologia Bildungsroman pode ser encontrada nos seguintes textos: MAZZARI, Marcus Vinicius. O Bildungsroman na Literatura Brasileira: Prolegômenos para um Estudo. In: Blickwechsel: Akten des XI. Lateinamerikanischen Germanistenkongresses, São Paulo, Paraty, Petrópolis 2003. Band II. São Paulo: Edusp, Monferrer Produções, 2005, pp. 85-92; e no texto de Wilma Patrícia Maas, citado na nota 17 de nosso trabalho. 
romance de Goethe, A Educação Sentimental, de Flaubert, o Grande Sertão: Veredas e o Berlin Alexanderplatz, não podemos simplesmente reduzi-los a uma modalidade que os aceite sem por eles ser modificada; ou seja, melhor procedimento é ocupar-se das particularidades de cada um dos romances mencionados, para então esboçar um plano em que situaremos as qualidades diversas observadas em diálogo.

Há uma carência, é certo, em nosso trabalho: ele não dedica maior atenção a uma análise dos romances de Goethe e Flaubert, embora os tome como paradigmas. $\mathrm{O}$ foco deste trabalho é o discurso do romance moderno tal como ele se apresenta em Döblin e Guimarães Rosa. Parte-se daí, portanto, para as relações seguintes que eles estabelecem com a sua suposta tradição.

O livro de Döblin, como vimos, filia-se ao Bildungsroman pelas mãos de Walter Benjamin, inicialmente ${ }^{109}$. Em nosso meio, Davi Arrigucci Jr., orientado por Benjamin, aproxima o Berlin Alexanderplatz do romance de Guimarães Rosa ${ }^{110}$. Com isso, temos que a polêmica segue, por exemplo, quando um outro crítico, José Antonio Pasta Jr., afirma que a lógica de base do Grande Sertão: Veredas configura "uma contradição insolúvel", que não propõe "síntese" ou "superação", mas conhece o movimento contínuo da "formação como supressão", que o afastaria

[...] a grande distância, do Wilhelm Meister, cujo modelo, sob muitos aspectos sociais, inverte. Inverter é ainda aproximar-se, mas, submetido ao ritmo da má infinidade, que por definição não conhece superação ou síntese, o romance de Rosa acaba por contrariar essencialmente o romance de formação clássico, que tem por eixo axiológico a renúncia à totalidade, o recorte nítido das identidades sexuais, a especialização produtiva, a crítica das aparências... ${ }^{111}$

Ao seguirmos o debate, com o mesmo interesse pelas movimentações do Grande Sertão: Veredas, discutimos em nosso trabalho conceitos, como o de "totalidade" na representação do romance, por exemplo, que não distanciam totalmente Döblin e

\footnotetext{
${ }^{109}$ Cf. o já citado Krisis des Romans, de 1930.

${ }^{110} \mathrm{Cf}$. o texto de Arrigucci já citado na nota 5 de nosso trabalho.

111 Cf. PASTA JÚNIOR, José Antonio. O Romance de Rosa. Temas do Grande Sertão e do Brasil. In: Novos Estudos CEBRAP. N. ${ }^{\circ}$ 55, novembro de 1999, p. 69.
} 
Guimarães Rosa da tradição do Bildungsroman, mas os aproximam dela, considerando que a impossibilidade de fechar uma "totalidade" plena é qualidade inerente ao discurso épico da modernidade, o romance. Mencionamos, em relação aos temas da "superação" e "síntese" e, por conseguinte, em relação ao problema da "totalidade" que se apreende com a observação da trajetória de uma personagem protagonista, que desde o Wilhelm Meisters Lehrjahre o encerramento de uma unidade satisfatória que se apresente como "síntese" traz consigo inevitavelmente problemas de várias ordens. Por exemplo, os sucessivos cortes que a realidade representada num romance faz na esfera dos anseios mais ingênuos de jovens protagonistas apaixonados como são Meister e Moreau levam à concepção de uma experiência cuja totalidade é uma resultante construída com elementos de desilusão e resignação, logo elementos supressivos.

Observemos, a seguir, um trecho do romance de Goethe em que Wilhelm parte do seu ambiente de origem para dar início às suas aventuras:

Percorreu lentamente vales e montanhas com um sentimento de grande prazer. Rochedos sobressalientes, ribeiros murmurejantes, escarpas cobertas de verdura, vales profundos, via-os ele aqui pela primeira vez; e, no entanto, os seus primeiros sonhos juvenis já haviam pairado por regiões assim. Diante daquela vista, sentia-se rejuvenescido; a sua alma estava lavada de todas as dores padecidas e foi com plena serenidade que ele recitou para si passagens de diversos poemas, em especial do Pastor Fido, que naqueles lugares solitários acudiam em massa à sua memória. Também se lembrava de várias passagens das suas próprias canções, que recitou com particular satisfação. Animou o mundo que se encontrava diante de si com todas as figuras do passado, e cada passo em direção ao futuro lhe parecia cheio do pressentimento de acções importantes e de acontecimentos notáveis ${ }^{112}$.

Ou então o breve trecho de $A$ Educação Sentimental, em que, ao ouvir a conversa de Pellerin sobre temas da arte, Moreau observa simultaneamente a sua amada senhora Arnoux, enquanto "as palavras caíam-lhe no espírito como metais numa fornalha,

\footnotetext{
112 GOETHE, Johann Wolfgang von. Os Anos de Aprendizagem de Wilhelm Meister. Tradução de Paulo Osório de Castro. Prefácio, notas e tradução das canções por João Barrento. Lisboa: Relógio D’Água Editores, 1998, pp. 120-121.
} 
juntavam-se à sua paixão e transformavam-se em amor"113. Nos dois fragmentos, o mundo exterior encontra no olhar dos protagonistas uma luz que o ilumina e embeleza, pleno de sentido e fulgor. Não podemos deixar de notar que daí, para as adaptações que os condicionam menos fantasiosos ao final dos dois romances, configura-se uma espécie de "supressão" nos anseios dos protagonistas, eles próprios ajustados a uma realidade menos "grandiosa", que é o que podemos entender da conversa-balanço que têm Moreau e seu amigo Deslauriers nas últimas páginas do livro de Flaubert ou da formação profissional específica que assume Meister no Wilhelm Meisters Wanderjahre, que contraria de algum modo seus desejos juvenis por uma "formação universal". Isso, por certo, retoma também o problema da disposição para a vida que alimentam os protagonistas desses romances, que não encontra uma correspondência simples nos casos dos romances de Guimarães Rosa e Döblin, embora os personagens centrais destes também nutram esperanças. Riobaldo narra ele mesmo sua trajetória, como rememoração, num procedimento que contamina aquilo que seriam suas "disposições iniciais" com um misto de lembranças e considerações do presente da narração. Por sua vez, Biberkopf em matéria de anseios não deseja mais que a "decência", ser um "homem decente", e não o Walter Scott da França, como Moreau, ou muito menos um próximo de Shakespeare, como Meister.

Ao atentarmos às trajetórias de Riobaldo e Biberkopf, constatamos também que as "supressões" nos desenvolvimentos de suas histórias colocam em jogo problemas mais radicais quanto à integração de suas vidas e idéias à realidade de seus entornos. Chega-se a intitular, como o fez Marcus Vinicius Mazzari, a trajetória de Biberkopf como uma “formação pela deformação", tendo em vista que em seu trajeto o protagonista de Berlin Alexanderplatz perde, inclusive, um de seus braços ${ }^{114}$.

O problema central, nos parece, e que distingue as experiências de Riobaldo e de Biberkopf como casos mais tensos que os de Moreau e Meister, é que o mundo circundante em transformação do qual aqueles participam é composto de uma incessante

\footnotetext{
113 FLAUBERT, Gustave. A Educação Sentimental. Tradução de Adolfo Casais Monteiro. São Paulo: Círculo do Livro S. A., s/d, p. 63. Em ambos os casos, isto é, nas citações de Goethe e de Flaubert, não deve ser ignorado a ironia do narrador.

${ }^{114}$ Cf. MAZZARI, Marcus Vinicius. Romance de Formação em Perspectiva Histórica - O Tambor de Lata de Günter Grass. São Paulo: Ateliê Editorial, 1999, p.87. Neste momento de seu livro, Mazzari aproxima o Berlin Alexanderplatz também do romance de Grass.
} 
movimentação que o define e dá o tom narrativo de seus romances. A despeito disso, não podemos excluir dos romances de Goethe e Flaubert elementos transitórios em alguns de seus constituintes. Por exemplo, a vida de Wilhelm Meister, como membro de uma companhia de teatro, é a de um nômade, bem como Frédéric Moreau não se fixa profissional e sentimentalmente (pelo menos até o momento de sua resignação, ou seja, o final do livro). Mas a movimentação nesses dois romances difere em muito da que encontramos em Grande Sertão: Veredas e Berlin Alexanderplatz, pela intensificação dos problemas reflexivos e da linguagem que compõem a realidade de Riobaldo e também pelo transtorno alarmante que gira em torno de Biberkopf como texto "da" metrópole. Em decorrência disso, em nosso trabalho não apenas observamos as mobilidades de Riobaldo e Biberkopf enquanto personagens que muito se deslocam no espaço e emocionalmente, mas também procuramos salientar a linguagem dos dois romances como operantes do transitório. Portanto, por um lado, não podemos afastar esses romances de Goethe e de Flaubert de um mesmo campo de investigação que inclui os livros de Rosa e Döblin, assim como não devemos considerá-los essencialmente opostos aos exemplares mais modernos, embora possamos reconhecer as distinções entre eles quando alinhados em uma única tradição.

Riobaldo sem Diadorim e transtornado pelo passado, Biberkopf sem Mieze e um braço, como personagens que traçam um percurso no espaço narrativo de seus livros, dão a entender que no processo de suas trajetórias as dificuldades são muitas e efetuam transformações significativas. Como resultante de seus trajetos, podemos constatar o estado de suas condições últimas, ou seja, um Riobaldo proprietário de terras, casado, religioso e aposentado de suas antigas atividades de jagunço; e um Franz Karl Biberkopf, sujeito outro, empregado como auxiliar de porteiro de uma empresa de médio porte e cidadão ajustado livre da criminalidade. Porém, como as condições últimas dessas personagens não constituem o núcleo de seus romances propriamente ${ }^{115}$, demos maior

\footnotetext{
${ }^{115}$ Não podemos esquecer, como ao longo de nosso trabalho fizemos, que a narrativa do Grande Sertão: Veredas se faz como rememoração de seu protagonista, portanto a perspectiva é a de um jagunço aposentado em suas atuais condições. Mas, neste momento, apenas frisamos que é a lembrança do passado no presente da fala de Riobaldo que se encarrega de compor o livro.
} 
atenção em nosso trabalho às movimentações de suas vidas, às andanças que parecem configurar as narrativas dos dois textos e jogar com seus significados:

Ah, tem uma repetição, que sempre outras vezes em minha vida acontece. Eu atravesso as coisas - e no meio da travessia não vejo! - só estava era entretido na idéia dos lugares de saída e de chegada. Assaz o senhor sabe: a gente quer passar um rio a nado, e passa; mas vai dar na outra banda é num ponto muito mais em baixo, bem diverso do em que primeiro se pensou. Viver nem não é muito perigoso? (GSV, p.35).

No trecho acima, por exemplo, o pensamento aparentemente imediatista de Riobaldo, além de, em grande medida, aproximá-lo neste aspecto de Franz Biberkopf, toca na questão de seu trânsito como fundamento de sua experiência. Se aceitarmos essa condição, será preferível examinar a movimentação de Riobaldo e sua fala a procurar pela síntese de sua trajetória, já que uma coisa, necessariamente, e no caso deste livro, compromete a outra. Quer dizer, o Riobaldo que menino admirou o bando de jagunços, aprendeu com Diadorim a amar, reconhecer e enfrentar seus medos; o Riobaldo que em momentos foge e em outros enfrenta, discursa, assume, e pactua, é um Riobaldo em conformidade com o movimento de sua incessante fala, que, tal como o vento que varre o orvalho das folhas, nega a formação de substâncias que sintetizem o processo pelo qual ele se transforma. O movimento está em tudo no romance de Rosa, ele é o seu sentido. Do mesmo modo, a linguagem do romance de Döblin que se quer análoga ao movimento de uma grande cidade é um trânsito constante de seus elementos urbanos. Franz Biberkopf, como parte de Berlim, é um ser cuja trajetória móvel substitui a condensação de uma unidade resultante estática; o sentido de seu percurso é sua mobilidade.

Quando, no início de nosso trabalho, imaginamos próximos o Grande Sertão: Veredas e o Berlin Alexanderplatz, esboçamos alguns dos problemas que a reunião levantaria. Procuramos solucionar a questão de um modo em que a distância, dentro do universo romanesco, entre os ambientes urbano e sertanejo parece-nos reduzida. Quem sabe com isso, aliviamos algo das inquietações sofridas por Riobaldo, que, diante das incertezas de suas observações sobre a mobilidade da vida sertaneja, recorre à imagem de 
uma grande cidade que o socorreria, e que poderia ser, talvez, a Berlim por onde tanto se moveu o seu não menos inquieto companheiro Franz Biberkopf:

Mas o sertão está movimentante todo-tempo - salvo que o senhor não vê; é que nem braços de balança, para enormes efeitos de leves pesos... Rodeando por terras tão longes; mas eu tinha raiva surda das grandes cidades que há, que eu desconhecia. Raiva porque eu não era delas, produzido... E naveguei salaz (GSV, p. 487).

Sertanejos ou citadinos, em Riobaldo e Biberkopf os giros são os mesmos, fundamentos em verbo e vento, encontram-se no espaço dos volteios dos romances de seus passos. 


\section{Bibliografia}

ADORNO, Theodor W. Posição do Narrador no Romance Contemporâneo. In: Notas de Literatura I. Tradução de Jorge de Almeida. São Paulo: Duas Cidades; Ed. 34, 2003. (Coleção Espírito Critico).

ANJOS, Cyro dos. O Amanuense Belmiro. $15^{\mathrm{a}}$ ed. Belo Horizonte: Livraria Garnier, 2000.

ANTÔNIO, João. Os Melhores Contos. Seleção de Antônio Hohfeldt. $2^{\mathrm{a}}$ ed. São Paulo: Global, 1997.

ARAÚJO, Heloísa Vilhena de. O Roteiro de Deus: Dois Estudos sobre Guimarães Rosa. São Paulo: Mandarim, 1996.

ARRIGUCCI JR. Davi. O Mundo Misturado. Romance e Experiência em Guimarães Rosa. In: Novos Estudos CEBRAP. N. ${ }^{\circ}$ 40, novembro de 1994, pp. 7-29.

ARROYO, Leonardo. A Cultura Popular em Grande Sertão: Veredas. Rio de Janeiro: José Olympio, 1984. (Coleção Documentos Brasileiros, N. $\left.{ }^{\circ} 195\right)$.

AUERBACH, Erich. Mimesis. A Representação da Realidade na Literatura Ocidental. $4^{\mathrm{a}}$ ed. São Paulo: Perspectiva, 2002.

BAKHTIN, Mikhail. Questões de Literatura e Estética. A Teoria do Romance. $5^{\mathrm{a}}$ ed. São Paulo: Editora UNESP/Hucitec, 2002.

BAKHTIN, Mikhail. A Cultura Popular na Idade Média e no Renascimento. O Contexto de François Rabelais. $5^{\text {a }}$ ed. São Paulo: Hucitec/Annablume, 2002.

BAKHTIN, Mikhail. Estética da Criação Verbal. 4a ed. São Paulo: Martins Fontes, 2003.

BAUDELAIRE, Charles. O Pintor da Vida Moderna. In: Poesia e Prosa. Ivo Barroso (org.). Rio de Janeiro: Nova Aguilar, 1995, pp. 851-881.

BECKER, Sabina. Urbanität und Moderne. Studien zur Großstadtwahrnehmung in der deutschen Literatur (1900-1930). St. Ingbert: Röhrig, 1993.

BENJAMIN, Walter. Krisis des Romans. Zu Döblins Berlin Alexanderplatz. In: Gesammelte Schriften III. Frankfurt am Main: Suhrkamp, 1972, pp. 230-236. Ed. brasileira: BENJAMIN, Walter. A Crise do Romance. In: Obras Escolhidas I. $7^{\mathrm{a}}$ ed. Tradução de Sergio Paulo Rouanet. São Paulo: Brasiliense, 1994, p. 54-60.

BENJAMIN, Walter. Der Autor als Produzent. Ed. brasileira: BENJAMIN, Walter. $O$ Autor como Produtor. Conferência Pronunciada no Instituto para o Estudo do Fascismo, 
em 27 de Abril de 1934. In: Obras Escolhidas I. $7^{\text {a }}$ ed. Tradução de Sergio Paulo Rouanet. São Paulo: Brasiliense, 1994, pp. 120-136.

BENJAMIN, Walter. Der Erzähler. Ed. brasileira: BENJAMIN, Walter. O Narrador. In: Obras Escolhidas I. $7^{a}$ ed. Tradução de Sergio Paulo Rouanet. São Paulo: Brasiliense, 1994, pp. 197-221.

BOLlE, Willi. Grandesertão.br. O Romance de Formação do Brasil. São Paulo: Duas Cidades; Ed. 34, 2004. (Coleção Espírito Critico).

BRECHT, Bertolt. Amplitude e Variedade do Modo de Escrever Realista. In: Estudos Avançados. № 34, v. 12, setembro/dezembro de 1998, pp. 267-276.

BUTOR, Michel. Repertório. São Paulo: Perspectiva, 1974.

CAMPOS, Haroldo de. A Linguagem do Iauaretê. In: Guimarães Rosa. Eduardo F. Coutinho (org.). 2 ${ }^{\mathrm{a}}$ ed. Rio de Janeiro: Civilização Brasileira, 1991, pp. 574-579. (Coleção Fortuna Crítica).

CANDIDO, Antonio. Jagunços Mineiros de Cláudio a Guimarães Rosa. In: Vários Escritos. 2a ed. São Paulo: Livraria Duas Cidades, 1977, pp. 133-160.

CANDIDO, Antonio. O Homem dos Avessos. In: Tese e Antítese. $4^{\mathrm{a}}$ ed. São Paulo: T. A. Queiroz, 2000, pp. 119-139.

CERTEAU, Michel de. A Invenção do Cotidiano. $6^{\mathrm{a}}$ ed. Petrópolis: Vozes, 2001.

CORNELSEN, Elcio Loureiro. Elementos do Pensamento Filosófico-Religioso de Alfred Döblin e seu Reflexo no Romance Berlim Alexanderplatz. São Paulo: USP - FFLCH. Dissertação de mestrado, 1995.

DANIEL, Mary L. João Guimarães Rosa: Travessia Literária. Rio de Janeiro: José Olympio, 1968.

Diversos Autores. Guimarães Rosa. Eduardo F. Coutinho (org.). 2a ed. Rio de Janeiro: Civilização Brasileira, 1991. (Coleção Fortuna Crítica).

Diversos Autores. Materialien zu Alfred Döblin Berlin Alexanderplatz. Matthias Prangel (org.). Frankfurt am Main: Suhrkamp, 1975.

Diversos Autores. Sobre o Romance no Século XX. A Reflexão dos Escritores Alemães. Teresa Seruya (org.). Lisboa: Edições Colibri, 1995.

DÖBLIN, Alfred. Berlin Alexanderplatz. Die Geschichte vom Franz Biberkopf. Frankfurt am Main: Suhrkamp, 2002. Ed. brasileira: DÖBLIN, Alfred. Berlim Alexanderplatz. A História de Franz Biberkopf. Tradução de Lya Luft. Rio de Janeiro: Rocco, 1995. Ed. 
portuguesa: DÖBLIN, Alfred. Berlim Alexanderplatz. A História de Franz Biberkopf. Tradução de Sara Seruya e Teresa Seruya. Lisboa: Dom Quixote, 1992.

FLAUBERT, Gustave. A Educação Sentimental. Tradução de Adolfo Casais Monteiro. São Paulo: Círculo do Livro S. A., s/d.

FLUSSER, Vilém. Guimarães Rosa oder: Das große Hinterland des Geistes. In: Merkur

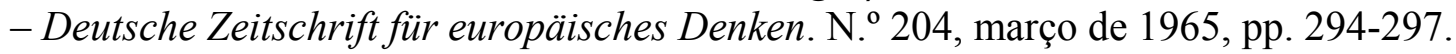

FOUCAULT, Michel. As Palavras e as Coisas. Uma Arqueologia das Ciências Humanas. $8^{\mathrm{a}}$ ed. Tradução de Salma Tannus Muchail. São Paulo: Martins Fontes, 2002.

FINAZZI-AGRÓ, Ettore. Um Lugar do Tamanho do Mundo. Tempos e Espaços da Ficção em João Guimarães Rosa. Belo Horizonte: Editora UFMG, 2001.

GARBUGLIO, José Carlos. Rosa em Dois Tempos. São Paulo: Nankin, 2005.

GOETHE, Johann Wolfgang von. Os Anos de Aprendizagem de Wilhelm Meister. Tradução de Paulo Osório de Castro. Prefácio, notas e tradução das canções por João Barrento. Lisboa: Relógio D’Água Editores, 1998.

GOETHE, Johann Wolfgang von. Fausto - Uma Tragédia - Primeira Parte. Tradução de Jenny Klabin Segal. São Paulo: Ed. 34, 2004.

GREGORY, Alceu João. O Romance O Tigre Azul como Forma Estética do Pensamento Histórico de Alfred Döblin. São Paulo: USP - FFLCH. Tese de doutorado, 2003.

HANSEN, João Adolfo. Terceira Margem. In: Revista do Instituto de Estudos Brasileiros. N. ${ }^{\circ}$ 41, 1996, pp. 51-67.

HANSEN, João Adolfo. $O$ O. A Ficção da Literatura em Grande Sertão: Veredas. São Paulo: Hedra, 2000.

JOCHHEIM, Gernot. Der Berliner Alexanderplatz. Berlin: Ch. Links Verlag, 2006.

JOZEF, Bella. O Romance Brasileiro e o Ibero-Americano na Atualidade. In: Guimarães Rosa. Eduardo F. Coutinho (org.). 2a ed. Rio de Janeiro: Civilização Brasileira, 1991, pp. 187-197. (Coleção Fortuna Crítica).

KELLER, Otto. Döblins Montageroman als Epos der Moderne. München: Wilhelm Fink, 1980.

KIESEL, Helmuth. Lesskow oder Döblin? Über die fragliche Grundlage der vielberufenen These von der Unmöglichkeit des Erzählens in der Moderne. In: Wirklichkeit der Kunst und das Abenteuer der Interpretation. Festschrift für HorstJürgen Gerigk. Klaus Manger (org.). Heidelberg: Winter, 1999, pp. 171-180. 
KIESEL, Helmuth. Geschichte der literarischen Moderne. Sprache-Ästhetik-Dichtung im zwanzigsten Jahrhundert. München: C. H. Beck, 2004.

KLOTZ, Volker. Die erzählte Stadt. Ein Sujet als Herausforderung des Romans von Lesage bis Döblin. München: Carl Hanser, 1969.

LAGES, Susana Kampff. João Guimarães Rosa e a Saudade. São Paulo: Ateliê Editorial; Fapesp, 2002.

LEDANFF, Susanne. Bildungsroman versus Großstadtroman. In: Sprache im technischen Zeitalter. N. ${ }^{\circ}$ 78. Walter Höllerer e Norbert Miller (orgs.). Berlin: Literarisches Colloquium Berlin e. V., 1981, pp. 85-114.

LIMA, Luiz Costa. Limites da Voz - Montaigne, Schlegel. Rio de Janeiro: Rocco, 1993.

LIMA, Luiz Costa. Limites da Voz - Kafka. Rio de Janeiro: Rocco, 1993.

LIMA, Luiz Costa. Mímesis: Desafio ao Pensamento. Rio de Janeiro: Civilização Brasileira, 2000.

LIMA, Luiz Costa. Mímesis e Modernidade. Formas das Sombras. $2^{\mathrm{a}}$ ed. São Paulo: Paz e Terra, 2003.

LUKÁCS, Georg. A Teoria do Romance. Tradução de José Marcos Mariani de Macedo. São Paulo: Duas Cidades; Ed. 34, 2000. (Coleção Espírito Critico).

MAAS, Wilma Patrícia. O Cânone Mínimo. O Bildungsroman na História da Literatura. São Paulo: Editora UNESP, 2000.

MAZZARI, Marcus Vinicius. O Mundo na Praça Alex. Artigo publicado no Jornal de Resenhas da Folha de São Paulo, em 8 de março de 1996.

MAZZARI, Marcus Vinicius. Romance de Formação em Perspectiva Histórica - O Tambor de Lata de Günter Grass. São Paulo: Ateliê Editorial, 1999.

MAZZARI, Marcus Vinicius. O Bildungsroman na Literatura Brasileira: Prolegômenos para um Estudo. In: Blickwechsel: Akten des XI. Lateinamerikanischen Germanistenkongresses, São Paulo, Paraty, Petrópolis 2003. Vol. II. São Paulo: Edusp, Monferrer Produções, 2005, pp. 85-92.

MELO NETO, João Cabral de. Obra Completa. Rio de Janeiro: Nova Aguilar, 1994.

MUSIL, Robert. Der Mann ohne Eigenschaften. Reinbek bei Hamburg: Rowohlt Taschenbuch, 2004. Ed. brasileira: O Homem sem Qualidades. Tradução de Lya Luft e Carlos Abbenseth. Rio de Janeiro: Nova Fronteira, 1989. 
NUNES, Benedito. O Amor na Obra de Guimarães Rosa. In: Guimarães Rosa. Eduardo F. Coutinho (org.). 2a ed. Rio de Janeiro: Civilização Brasileira, 1991, pp. 144-169. (Coleção Fortuna Crítica).

PASTA JÚNIOR, José Antonio. O Romance de Rosa. Temas do Grande Sertão e do Brasil. In: Novos Estudos CEBRAP. N. ${ }^{\circ}$ 55, novembro de 1999.

PROENÇA, M. Cavalcanti. Trilhas no Grande Sertão. Rio de Janeiro: MEC/Departamento de Imprensa Nacional, 1958. (Os Cadernos de Cultura, N. ${ }^{\circ}$ 114).

RODRIGUES, Nelson. Flor de Obsessão. São Paulo: Companhia das Letras, 1997.

ROSA, João Guimarães. Grande Sertão: Veredas. $2^{\mathrm{a}}$ ed. Rio de Janeiro: José Olympio, 1958.

ROSENFELD, Anatol. Reflexões sobre o Romance Moderno. In: Texto/Contexto. $4^{\mathrm{a}}$ ed. São Paulo: Perspectiva, 1985, pp. 75-97.

ROSENFELD, Anatol. A Confusão de Babel: Alfred Döblin. In: Letras Germânicas. São Paulo: Perspectiva; Edusp; EdUNICAMP, 1993, pp. 165-171. (Artigo publicado inicialmente no Suplemento Literário de $O$ Estado de $S$. Paulo, em 28 de fevereiro de 1959).

ROSKOTHEN, Johannes. Verkehr. Zu einer poetischen Theorie der Moderne. München: Wilhelm Fink Verlag, 2003.

SCHERPE, Klaus R.. Von der erzählten Stadt zur Stadterzählung. Der Großstadtdiskurs in Alfred Döblins "Berlin Alexanderplatz". In: Diskurstheorien und Literaturwissenschaft. Jürgen Fohrmann e Harro Müller (orgs.). Frankfurt am Main: Suhrkamp, 1988, pp. 418-437.

SCHERPE, Klaus R.. Nonstop nach Nowhere City? Wandlungen der Symbolisierung, Wahrnehmung und Semiotik der Stadt in der Literatur der Moderne. In: Die Unwirklichkeit der Städte. Großstadtdarstellungen zwischen Moderne und Postmoderne. Reinbek bei Hamburg: Rowohlt, 1988, pp. 129-152.

SCHERPE, Klaus R.. Ausdruck, Funktion, Medium. Transformationen der Großstadterzählung in der deutschen Literatur der Moderne. In: Literatur in einer industriellen Kultur. Götz Grossklaus e Eberhard Lämmert (orgs.). Stuttgart: Cotta, 1989, pp. 139-161.

SCHERPE, Klaus R.. Berlin als Ort der Moderne. In: Pandaemonium Germanicum Revista de Estudos Germanísticos. No 7. São Paulo: Humanitas/FFLCH/USP, 2003, pp. 17-37. 
SCHLEGEL, Friedrich. Conversa sobre a Poesia e Outros Fragmentos. Tradução, prefácio e notas de Victor-Pierre Stirnimann. São Paulo: Iluminuras, 1994.

SCHLAFFER, Heinz. Poesie und Wissen. Die Entstehung des ästhetischen Bewußtseins und der philologischen Erkenntnis. Frankfurt am Main: Suhrkamp, 1990.

SCHRÖTER, Klaus. Döblin. 6a ed. Reinbek bei Hamburg: Rowohlt, 1999.

SODRÉ, Nelson Werneck. Um Caso Singular. Artigo publicado nas Notas de Crítica do jornal Última Hora de São Paulo, em 16 de novembro de 1956.

SOUSA, Celeste H. M. Ribeiro de. Berlin Alexanderplatz, Romance de Vanguarda. In: Pandaemonium Germanicum - Revista de Estudos Germânicos. N. ${ }^{\circ}$ 1. São Paulo: Humanitas/FFLCH/USP, 1997, pp. 33-43.

UTÉZA, Francis. JGR: Metafisicica do Grande Sertão. Trad. de José Carlos Garbuglio. São Paulo: Edusp, 1994.

VERNANT, Jean-Pierre. Aspectos Míticos da Memória. In: Mito e Pensamento entre os Gregos. 2a ed. Rio de Janeiro: Paz e Terra, 2002, pp. 135-166.

WARD, Teresinha Souto. O Discurso Oral em Grande Sertão: Veredas. São Paulo: Duas Cidades; INL, Fundação Nacional Pró-Memória, 1984. 